Prepared in cooperation with the West Virginia Department of Environmental Protection, Division of Water and Waste Management

\title{
Groundwater Quality in West Virginia, 1993-2008
}

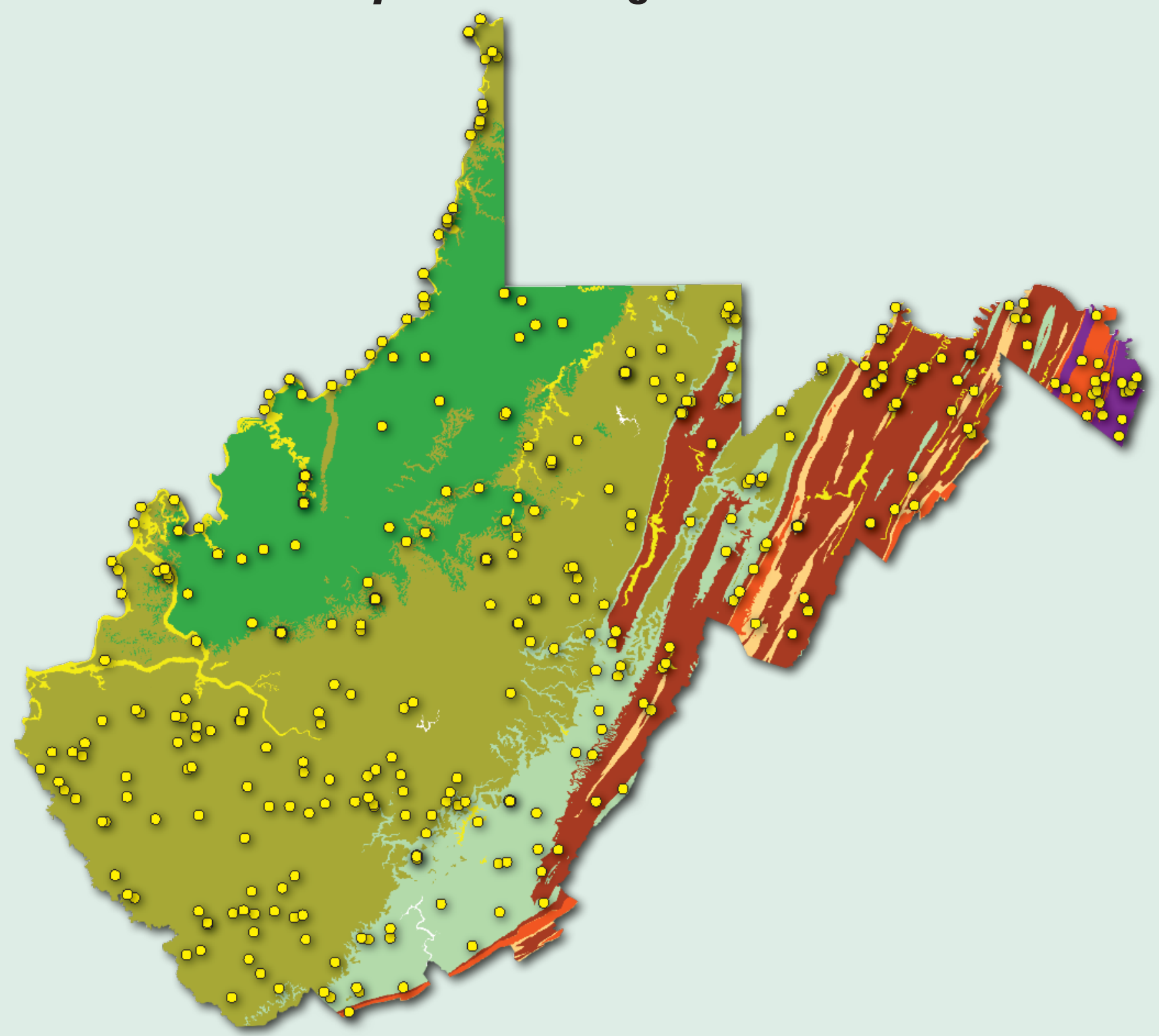

Scientific Investigations Report 2012-5186 
Cover. The geology of West Virginia and locations of groundwater-quality sampling sites, wells, and springs, in the West Virginia ambient monitoring network, 1993-2008. See figure 1 for an explanation of the geology. 


\section{Groundwater Quality in West Virginia, 1993-2008}

By Douglas B. Chambers, Mark D. Kozar, Jeremy S. White, and Katherine S. Paybins

Prepared in cooperation with

the West Virginia Department of Environmental Protection,

Division of Water and Waste Management

Scientific Investigations Report 2012-5186 


\title{
U.S. Department of the Interior \\ KEN SALAZAR, Secretary \\ U.S. Geological Survey \\ Marcia K. McNutt, Director
}

\author{
U.S. Geological Survey, Reston, Virginia: 2012
}

For more information on the USGS - the Federal source for science about the Earth, its natural and living resources, natural hazards, and the environment, visit http://www.usgs.gov or call 1-888-ASK-USGS.

For an overview of USGS information products, including maps, imagery, and publications, visit http://www.usgs.gov/pubprod

To order this and other USGS information products, visit http://store.usgs.gov

Any use of trade, product, or firm names is for descriptive purposes only and does not imply endorsement by the U.S. Government.

Although this report is in the public domain, permission must be secured from the individual copyright owners to reproduce any copyrighted materials contained within this report.

Suggested citation:

Chambers, D.B., Kozar, M.D., White, J.S., and Paybins, K.S., 2012, Groundwater quality in West Virginia, 1993-2008: U.S. Geological Survey Scientific Investigations Report 2012-5186, 47 p. 


\section{Contents}

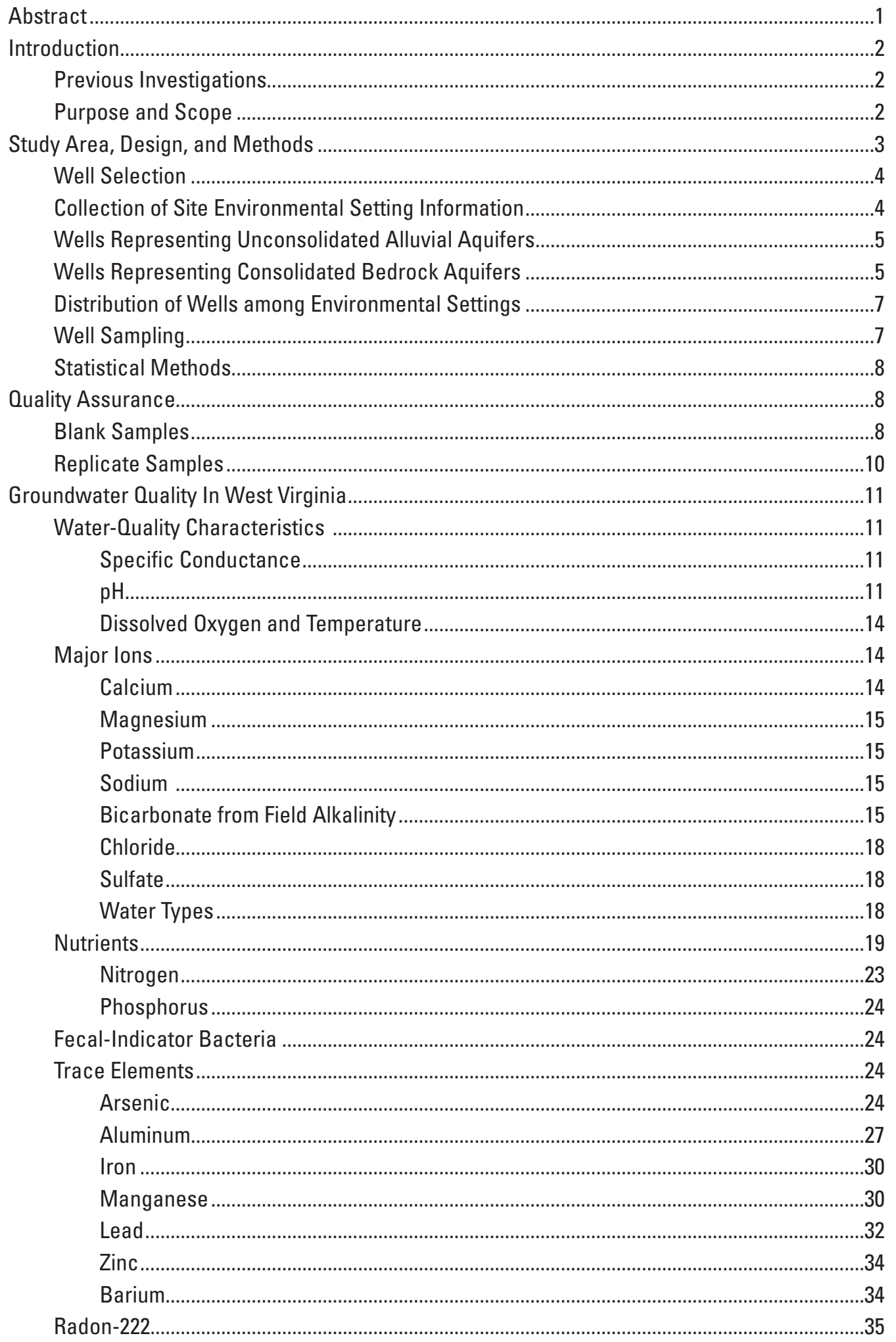




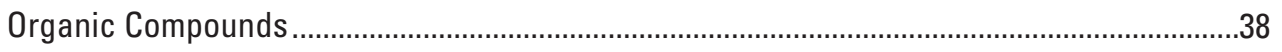

Volatile Organic Compounds.....................................................................................38

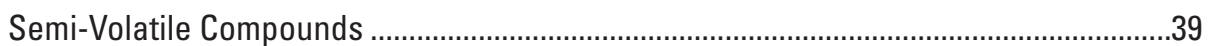

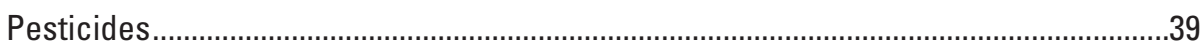

Relations Among Water-Quality Characteristics and Environmental Settings ..............................42

Implications for Further Studies of West Virginia Groundwater Resources ....................................43

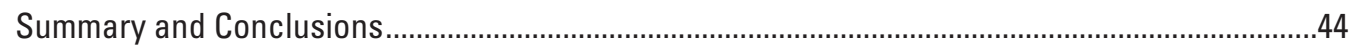

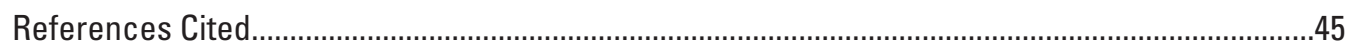

\section{Figures}

1. Map showing the geology of West Virginia and locations of groundwater-quality sampling sites, wells, and springs in the West Virginia ambient monitoring network, 1993-2008

2. Boxplots showing distribution of specific conductance values in groundwater samples from the West Virginia ambient monitoring network, grouped by geologic age of the aquifers, 1993-2008

3. Boxplots showing distribution of $\mathrm{pH}$ in groundwater samples from the West Virginia ambient monitoring network, grouped by geologic age of the aquifers, 1993-2008 .......12

4. Map showing distribution of $\mathrm{pH}$ values for all groundwater samples from the West Virginia ambient monitoring network, 1993-2008.

5. Boxplots showing distribution of calcium concentrations in groundwater samples from the West Virginia ambient monitoring network, grouped by geologic age of the aquifers, 1993-2008

6. Boxplots showing distribution of magnesium concentrations in groundwater samples from the West Virginia ambient monitoring network, grouped by geologic age of the aquifers, 1993-2008

7. Boxplots showing distribution of potassium concentrations in groundwater samples from the West Virginia ambient monitoring network, grouped by geologic age of the aquifers, 1993-2008.

8. Boxplots showing distribution of sodium concentrations in groundwater samples from the West Virginia ambient monitoring network, grouped by geologic age of the aquifers, 1993-2008

9. Boxplots showing distribution of bicarbonate in groundwater samples from the West Virginia ambient monitoring network, grouped by geologic age of the aquifers, 1993-2008

10. Boxplots showing distribution of chloride concentrations in groundwater samples from the West Virginia ambient monitoring network, grouped by geologic age of the aquifers, 1993-2008.

11. Boxplots showing distribution of sulfate concentrations in groundwater samples from the West Virginia ambient monitoring network, grouped by geologic age of the aquifers, 1993-2008. 
12. Piper trilinear plots of indicating major ion composition of groundwater samples from the West Virginia ambient monitoring network, grouped by geologic age of the aquifers, 1993-2008: $A$, Quaternary aquifers; $B$, Cambrian, Ordovician, and Silurian aquifers; $C$, Devonian aquifers; $D$, Mississippian aquifers; $E$, Pennsylvanian aquifers; and $F$, Permian aquifers.

13. Boxplots showing distribution of nitrate and nitrite concentrations in groundwater samples from the West Virginia ambient monitoring network, grouped by geologic age of the aquifers, 1993-2008

14. Maps showing distribution of groundwater samples from the West Virginia ambient monitoring network with at least one colony-forming unit of fecal indicator bacteria per 100 milliliters of sample, 1993-2008: A, Fecal coliform and B, Escherichia coli.......25

15. Map showing distribution of groundwater samples from the West Virginia ambient monitoring network analyzed for total arsenic, 1993-2008...

16. Boxplots showing distribution of aluminum concentrations in groundwater samples from the West Virginia ambient monitoring network, grouped by geologic age of the aquifers, 1993-2008.

17. Map showing distribution of groundwater samples from the West Virginia ambient monitoring network analyzed for total aluminum, 1993-2008.

18. Boxplots showing distribution of iron concentrations in groundwater samples from the West Virginia ambient monitoring network, grouped by geologic age of the aquifers, 1993-2008.

19. Map showing distribution of groundwater samples from the West Virginia ambient monitoring network analyzed for total iron, 1993-2008

20. Boxplots showing distribution of manganese concentrations in groundwater samples from the West Virginia ambient monitoring network, grouped by geologic age, 1993-2008

21. Map showing distribution of groundwater samples from the West Virginia ambient monitoring network analyzed for total manganese, 1993-2008

22. Boxplots showing distribution of zinc concentrations in groundwater samples from the West Virginia ambient monitoring network, grouped by geologic age of the aquifers, 1993-2008

23. Map showing distribution of groundwater samples from the West Virginia ambient monitoring network analyzed for total barium, 1993-2008.

24. Boxplots showing distribution of barium concentrations in groundwater samples from the West Virginia ambient monitoring network, grouped by geologic age of the aquifers, 1993-2008.

25. Boxplots showing distribution of radon-222 in groundwater samples from the West Virginia ambient monitoring network, grouped by geologic age, 1993-2008

26. Map showing distribution of groundwater samples from the West Virginia ambient monitoring network analyzed for radon-222, 1993-2008.

27. Boxplots showing distribution of the number of volatile organic compounds detected per groundwater sample from the West Virginia ambient monitoring network, grouped by dominant rock type, 1993-2008

28. Map showing distribution of samples from the West Virginia ambient monitoring network analyzed for pesticides and the number of pesticides detected per groundwater sample, 1993-2008

29. Boxplots showing distribution of the number of pesticides detected per groundwater sample from the West Virginia ambient monitoring network, grouped by dominant rock type, 1993-2008 


\section{Tables}

1. Aquifer settings represented in the design of the ambient groundwater waterquality network

2. The distribution of samples by geologic age of aquifer ..................................................

3. Water-quality characteristics, major ions, metals, trace elements, nutrients, radon-222, and fecal indicator bacteria analyzed for in groundwater samples from the West Virginia ambient monitoring network, 1993-2008.

4. Statistical summary of major ions for groundwater samples from West Virginia ambient monitoring network, 1993-2008..

5. Statistical summary of metals and trace elements for groundwater samples from West Virginia ambient monitoring network, 1993-2008......

6. Volatile organic compounds analyzed for in groundwater samples from West Virginia ambient monitoring network, 1993-2008.

7. Semi-volatile organic compounds analyzed for in selected groundwater samples from the West Virginia ambient monitoring network, 1993-2008.

8. Pesticides and pesticide degradates analyzed for in 77 groundwater samples from the West Virginia ambient monitoring network, 1993-2008.

9. Principal components analysis showing distribution of eigenvector loadings for the first two principal components for samples from the West Virginia ambient monitoring network, 1993-2008 


\section{Conversion Factors}

Inch/Pound to SI

\begin{tabular}{|c|c|c|}
\hline Multiply & By & To obtain \\
\hline \multicolumn{3}{|c|}{ Length } \\
\hline inch (in) & 2.54 & centimeter $(\mathrm{cm})$ \\
\hline inch (in) & 25.4 & millimeter (mm) \\
\hline foot (ft) & 0.3048 & meter $(\mathrm{m})$ \\
\hline mile (mi) & 1.609 & kilometer $(\mathrm{km})$ \\
\hline yard (yd) & 0.9144 & meter $(\mathrm{m})$ \\
\hline \multicolumn{3}{|c|}{ Area } \\
\hline square mile $\left(\mathrm{mi}^{2}\right)$ & 259.0 & hectare (ha) \\
\hline square mile $\left(\mathrm{mi}^{2}\right)$ & 2.590 & square kilometer $\left(\mathrm{km}^{2}\right)$ \\
\hline \multicolumn{3}{|c|}{ Volume } \\
\hline gallon (gal) & 3.785 & $\operatorname{liter}(\mathrm{L})$ \\
\hline million gallons (Mgal) & 3,785 & cubic meter $\left(\mathrm{m}^{3}\right)$ \\
\hline cubic inch $\left(\mathrm{in}^{3}\right)$ & 16.39 & cubic centimeter $\left(\mathrm{cm}^{3}\right)$ \\
\hline \multicolumn{3}{|c|}{ Mass } \\
\hline ounce, avoirdupois (oz) & 28.35 & $\operatorname{gram}(\mathrm{g})$ \\
\hline ton per year (ton/yr) & 0.9072 & metric ton per year \\
\hline
\end{tabular}

Temperature in degrees Celsius $\left({ }^{\circ} \mathrm{C}\right)$ may be converted to degrees Fahrenheit $\left({ }^{\circ} \mathrm{F}\right)$ as follows:

${ }^{\circ} \mathrm{F}=\left(1.8 x^{\circ} \mathrm{C}\right)+32$

Temperature in degrees Fahrenheit $\left({ }^{\circ} \mathrm{F}\right)$ may be converted to degrees Celsius $\left({ }^{\circ} \mathrm{C}\right)$ as follows:

${ }^{\circ} \mathrm{C}=\left({ }^{\circ} \mathrm{F}-32\right) / 1.8$

Vertical coordinate information is referenced to the North American Vertical Datum of 1988 (NAVD 88).

Horizontal coordinate information is referenced to the North American Datum of 1983 (NAD 83).

Altitude, as used in this report, refers to distance above the vertical datum.

*Transmissivity: The standard unit for transmissivity is cubic foot per day per square foot times foot of aquifer thickness $\left[\left(\mathrm{ft}^{3} / \mathrm{d}\right) / \mathrm{ft}^{2}\right] \mathrm{ft}$. In this report, the mathematically reduced form, foot squared per day $\left(\mathrm{ft}^{2} / \mathrm{d}\right)$, is used for convenience.

Specific conductance is given in microsiemens per centimeter at 25 degrees Celsius $(\mu \mathrm{S} / \mathrm{cm}$ at $\left.25^{\circ} \mathrm{C}\right)$.

Concentrations of chemical constituents in water are given either in milligrams per liter (mg/L) or micrograms per liter $(\mu \mathrm{g} / \mathrm{L})$. 


\title{
Groundwater Quality in West Virginia, 1993-2008
}

\author{
By Douglas B. Chambers, Mark D. Kozar, Jeremy S. White, and Katherine S. Paybins
}

\section{Abstract}

Approximately 42 percent of all West Virginians rely on groundwater for their domestic water supply. However, prior to 2008, the quality of the West Virginia's groundwater resource was largely unknown. The need for a statewide assessment of groundwater quality prompted the U.S. Geological Survey (USGS), in cooperation with West Virginia Department of Environmental Protection (WVDEP), Division of Water and Waste Management, to develop an ambient groundwater-quality monitoring program.

The USGS West Virginia Water Science Center sampled 300 wells, of which 80 percent were public-supply wells, over a 10-year period, 1999-2008. Sites for this statewide ambient groundwater-quality monitoring program were selected to provide wide areal coverage and to represent a variety of environmental settings. The resulting 300 samples were supplemented with data from a related monitoring network of 24 wells and springs.

All samples were analyzed for field measurements (water temperature, $\mathrm{pH}$, specific conductance, and dissolved oxygen), major ions, trace elements, nutrients, volatile organic compounds, fecal indicator bacteria, and radon-222. Sub-sets of samples were analyzed for pesticides or semivolatile organic compounds; site selection was based on local land use.

Samples were grouped for comparison by geologic age of the aquifer. Groups included Cambrian, Ordovician, Silurian, Devonian, Pennsylvanian, Permian, and Quaternary aquifers. A comparison of samples indicated that geologic age of the aquifer was the largest contributor to variability in groundwater quality.

This study did not attempt to characterize drinking water provided through public water systems. All samples were of raw, untreated groundwater. Drinking-water criteria apply to water that is served to the public, not to raw water. However, drinking-water criteria, including U.S. Environmental Protection Agency (USEPA) maximum contaminant level (MCL), non-enforceable secondary maximum contaminant level (SMCL), non-enforceable proposed MCL, or non-enforceable advisory health-based screening level (HBSL), were used as benchmarks against which to compare analytical results.

Constituent concentrations were less than the MCLs in most samples. However, some samples exceeded non-enforceable SMCLs, proposed MCLs, or advisory HBSLs. Radon-222 concentrations exceeded the proposed MCL of 300 picocuries per liter $(\mathrm{pCi} / \mathrm{L})$ in 45 percent of samples, and iron concentrations exceeded the SMCL of 300 micrograms per liter $(\mu \mathrm{g} / \mathrm{L})$ in 57 percent of samples. Manganese concentrations were greater than the SMCL $(50 \mu \mathrm{g} / \mathrm{L})$ in 62 percent of samples and greater than the HBSL $(300 \mu \mathrm{g} / \mathrm{L})$ in 25 percent of the samples. Other sampled constituents, including organic compounds and trace elements, exceeded drinking-water criteria at much lower frequencies.

The radon-222 median concentrations in samples from Cambrian, Ordovician, Silurian, Permian, and Quaternary aquifers exceeded the proposed $300 \mathrm{pCi} / \mathrm{L} \mathrm{MCL}$. Although median radon concentrations for wells in Devonian, Mississippian, and Pennsylvanian aquifers were less than the proposed $\mathrm{MCL}$, radon concentrations greater than the proposed $\mathrm{MCL}$ were measured in samples from aquifers of all geologic ages.

The median iron concentrations for samples from Devonian and Pennsylvanian aquifers were greater than the $300 \mu \mathrm{g} / \mathrm{L}$ SMCL. Iron concentrations exceeded the SMCL in aquifers of all geologic ages, except Cambrian. Median concentrations of manganese exceeded the SMCL in samples from Devonian, Pennsylvanian, and Quaternary aquifers. As with iron, manganese concentrations were found to exceed the SMCL in at least one sample from aquifers of all geologic ages, except Cambrian.

Pesticides were detected most frequently and in higher concentrations in limestone-dominated areas. Most of West Virginia's agriculture is concentrated in those areas.

This study, the most comprehensive assessment of West Virginia groundwater quality to date, indicates the water quality of West Virginia's groundwater is generally good; in the majority of cases raw-water samples met primary drinking water-criteria. However, some constituents, notably iron and manganese, exceeded the secondary drinking-water criteria in more than half the samples. 


\section{Introduction}

Groundwater is an important resource for the people of West Virginia. The use of groundwater has been most recently described by Atkins (2007). Approximately 70 million gallons of groundwater per day (Mgal/d) are withdrawn to supply the 42 percent of all West Virginians who rely on groundwater for their domestic water supply, including drinking water. Of that 42 percent of West Virginians reliant upon groundwater resources for domestic water use, 23 percent obtain water from privately owned wells and 19 percent from public-supply wells. Water census data from 2004 show that industry, irrigation, commercial, and mining uses accounted for 54 million gallons per day (Mgal/d) in groundwater withdrawals. Commercial groundwater use, which includes restaurants and motels as well as churches and schools, was estimated to be $16 \mathrm{Mgal} / \mathrm{d}$ in 2004.

Although widely used and generally considered to be of good quality, West Virginia's groundwater resources are not without problems. These range from "nuisance" problems, such as staining of fixtures by high iron and manganese concentrations, to the presence of contaminants at concentrations that have possible adverse human health effects. Fecal-indicator bacteria and nutrients occur in groundwater throughout West Virginia, indicating the susceptibility of groundwater to contamination from surface sources. The variability of specific water-quality characteristics across the State is likely attributable to regional variations in environmental setting, such as local lithology and principal aquifer characteristics, land use and land cover, well construction, and topographic setting.

Since 1993, the U.S. Geological Survey (USGS) West Virginia Water Science Center, in cooperation with the West Virginia Department of Environmental Protection (WVDEP), Division of Water and Waste Management, has collected groundwater samples in an effort to characterize the ambient quality of the State's groundwater. The initial statewide ambient groundwater-quality monitoring program's study design called for the collection of samples from 17 wells and 9 springs selected to represent the differences in hydrogeologic settings throughout West Virginia. However, in 1999 the approach was changed to improve the geographic coverage of the sampling.

\section{Previous Investigations}

An earlier statewide analysis of groundwater quality (Mathes and others, 1998) was conducted by analyzing existing data available in the USGS National Water Information System (NWIS) database and data for the 26 sites that comprised the initial statewide ambient groundwater monitoring network. Results of that investigation did not indicate any statistically significant seasonal variation in groundwater quality. The highest median nitrate plus nitrite concentrations were present in water from Cambro-Ordovician limestone aquifers. Median dissolved manganese concentrations typically exceeded the 50 micrograms per liter $(\mu \mathrm{g} / \mathrm{L})$ U.S.
Environmental Protection Agency (USEPA) secondary maximum contaminany level (SMCL) (U.S. Environmental Protection Agency, 2009b) in water samples from Lower-, Middle-, and Upper-Pennsylvanian; Devonian; and Holocene alluvial aquifers. Median dissolved iron concentrations typically exceeded the $300 \mu \mathrm{g} / \mathrm{L}$ USEPA SMCL (U.S. Environmental Protection Agency, 2009b) in water samples from Lower- and Middle-Pennsylvanian and Devonian aquifers. Median dissolved concentrations of iron and manganese were greatest in water from shallow wells and from wells in valley settings. Statistically significant relations of sodium and calcium concentrations in water with well depth indicated the occurrence of cation- exchange processes.

McCoy and Kozar (2007) used dissolved gases in groundwater of West Virginia, collected as part of the statewide ambient groundwater-quality monitoring program, to define a relation between groundwater age and topographic setting in the Appalachian Plateaus Physiographic Province (Fenneman and Johnson, 1946); older waters were found in valley settings, and younger waters dominated in hilltop wells. A similar pattern was not found in the Valley and Ridge Physiographic Province. The dissolved gas data set also included methane concentrations (White and Mathes, 2006; Mathes and White, 2006). Methane, a combustible gas that can accumulate in confined spaces at explosive levels, was found in concentrations exceeding the U.S. Office of Surface Mining's action level of 28 milligrams per liter ( $\mathrm{mg} / \mathrm{L}$ ) (Eltschlager and others, 2001) in samples from some wells, primarily in West Virginia's southern coal fields.

Patterns of land use can affect the water quality of underlying aquifers. Agricultural practices in West Virginia are concentrated in areas of Quaternary alluvium or limestone lithologies with high transmissivities (Kozar and Mathes, 2001). Much of West Virginia's chemical industry is located in areas with alluvial aquifers that are very susceptible to surface contamination (Kozar and Mathes, 2001). Coal mining, a major land use in much of West Virginia, can affect groundwater quality (McAuley and Kozar, 2006). Concentrations of several dissolved constituents considered to be characteristic of coal mining, including but not limited to sulfate, iron, manganese, and total dissolved solids, were significantly higher in wells adjacent to mined areas (McAuley and Kozar, 2006).

\section{Purpose and Scope}

The purpose of this report is to summarize groundwaterquality data collected as part of cooperative USGS-WVDEP monitoring program for public-supply wells and to examine relations among water-quality characteristics and the environmental setting of the sampled wells. Results from field measurements and laboratory analyses of groundwater samples are used to describe physical and chemical properties and concentrations of fecal indicator bacteria, major ions, nutrients, trace elements, and radon. Subsets of samples are further analyzed to determine the concentrations of pesticides, semi-volatile 
organic compounds, volatile organic compounds, and dissolved gases. A summary of dissolved gas data collected as part of this study can be found in McCoy and Kozar (2007).

\section{Study Area, Design, and Methods}

West Virginia lies entirely within the Appalachian Mountains with parts of the State in three physiographic provinces (Fenneman and Johnson, 1946), regions with similar rock types and groundwater characteristics. The western and central parts of the State lie within the Appalachian Plateaus Physiographic Province. The Appalachian Plateaus consist of sub-horizontal consolidated sedimentary rocks of Devonian to
Permian age (fig. 1). These rocks have been highly dissected by stream erosion resulting in steep hills and deeply incised valleys. Valleys are filled in part with unconsolidated sediments of Quaternary age.

The eastern part of the State lies primarily in the Valley and Ridge Physiographic Province, named for the series of northeast-southwest trending valleys and ridges formed from Cambrian to Silurian aquifers. These strata are consolidated sedimentary rocks that are extensively faulted and sharply folded. The Blue Ridge Physiographic Province includes only the very easternmost edge of the Eastern Panhandle of West Virginia. In contrast to the sedimentary rocks of the Appalachian Plateaus and Valley and Ridge Physiographic Provinces, the Blue Ridge Physiographic Province is underlain by crystalline rock.

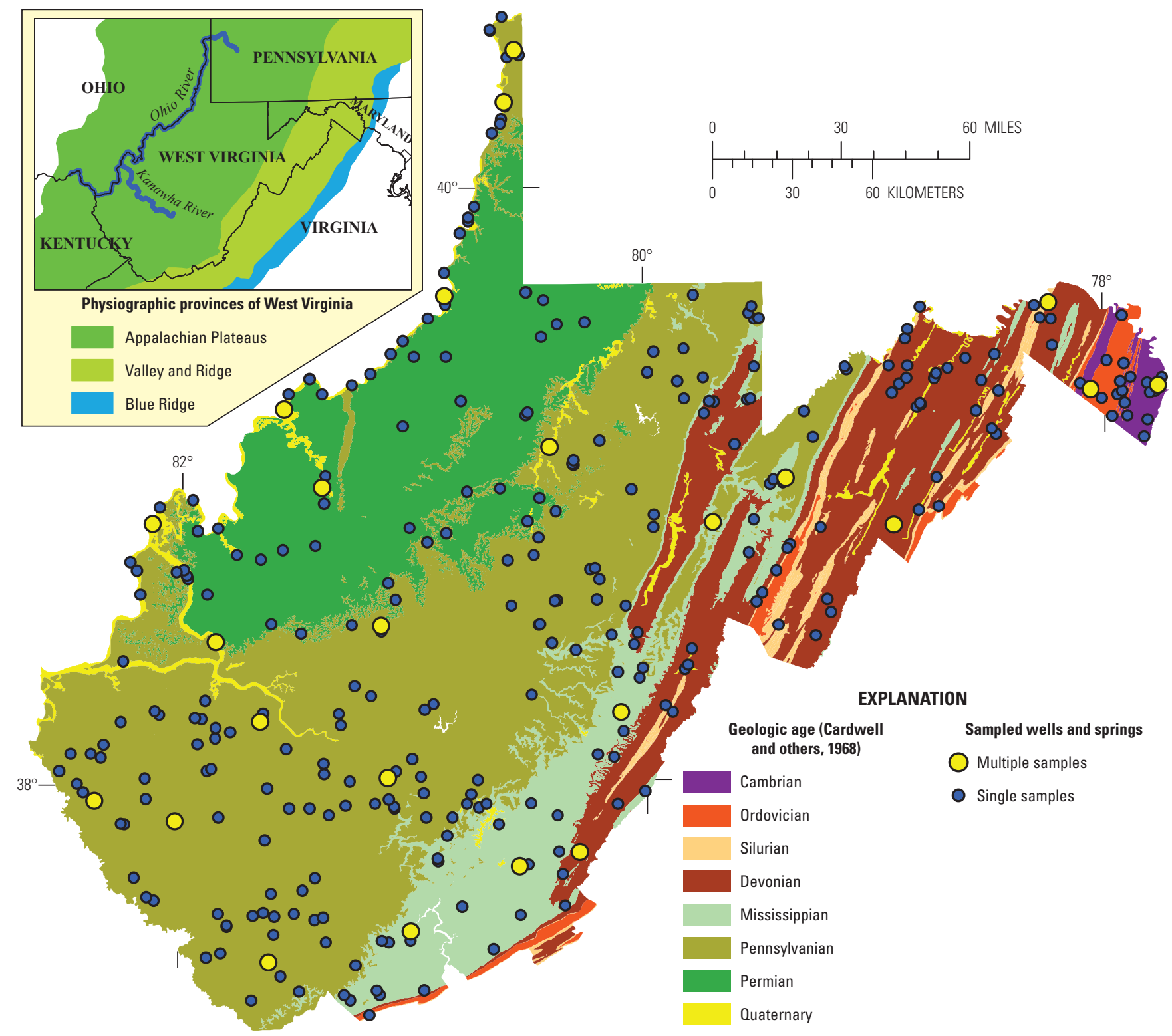

Figure 1. The geology of West Virginia and locations of groundwater-quality sampling sites, wells, and springs in the West Virginia ambient monitoring network, 1993-2008. 
Two aquifer types, unconsolidated alluvial deposits and sedimentary bedrock aquifers, underlie most of West Virginia (Kozar and Brown, 1995). The alluvial aquifers occur primarily along the Ohio and Kanawha Rivers. Seven bedrock aquifers, ranging in geologic age from Cambrian to Permian, underlie most of West Virginia (Puente, 1985). These principal aquifers differ in hydraulic characteristics, such as specific capacity, specific yield, and transmissivity (Kozar and Mathes, 2001), and in water quality (Kozar and Brown, 1995).

One of the strongest influences on groundwater-quality characteristics is aquifer geology. Sites were selected in a way that would best represent the local environmental setting, provide the best areal coverage of the State, and represent a variety of topographic settings. The environmental settings were considered to be a combination of the dominant aquifer type and aquifer age, physiography, and topographic setting. The two major aquifer types in West Virginia are unconsolidated alluvium of Quaternary age and consolidated bedrock aquifers, which range from Permian- to Cambrian-aged aquifers. As previously mentioned, West Virginia lies in the Appalachian Plateaus, Valley and Ridge, and Blue Ridge Physiographic Provinces. Topographic settings consisted of valley, hillside, or hilltop settings.

\section{Well Selection}

Wells throughout West Virginia were sampled as part of this study (fig. 1). Wells were selected from a database of public-supply wells maintained by the West Virginia Bureau for Public Health. To provide additional geographic coverage in areas with few public-supply wells, domestic wells, USGS water-level network wells, other types of wells, or springs were sampled.

Minimum criteria for a well to be considered for sampling were (1) well less than 25 years old, (2) minimum yield of 5 gallons per minute, and (3) adequate plumbing system for sampling water prior to treatment. The minimum information required for each well included well depth, length of casing, location (latitude/longitude), and contributing geologic unit (aquifer). Available well-construction information was recorded (age, depth, and casing length). Copies of driller's logs were obtained where available. However, as these logs were not required throughout the majority of the period in which the wells were drilled they were not available for nearly 90 percent of the wells. An on-site inspection was conducted to identify signs of the well for rust in the casing and adequate well pad construction to prevent surface contaminants entering the well bore. Existing submersible pumps were most commonly used for water-sample collection, but in a small number of wells, turbine pumps, jet pumps, or a portable submersible pump were used. Well and site characteristics were obtained during a site visit, from drilling logs, and from well-owner records, where available. If both the minimum criteria and the minimum information requirements were met, the well was selected for sampling.
Each year during 1999-2008, a set of 30 wells, most of which were public-supply wells, was selected for one-time sampling. The result is a dataset of 300 wells sampled over the 10-year period, 1999-2008, since the new sampling regimen was implemented. Data from the 300 samples were combined with data from a representative sample from each of 15 wells, two wells were excluded due to incomplete data sets, and nine springs in the initial program. The representative samples were selected on the basis of central tendency of the sample among all samples from that site and completeness of data. This selection process yielded 324 wells of which 239 were publicsupply wells, 45 were domestic wells, and the remainder a mix of industrial, mining, and other uses.

\section{Collection of Site Environmental Setting Information}

A geographic information system (GIS) was used to assemble information to define the environmental setting of individual well sites. Each well was attributed with spatial data describing the geology, land cover, elevation, and other factors, all of which are described in detail below.

Surficial geology for each well was determined using a 200- or a 300-meter radius buffer around the well overlain with the 1:250,000-scale surficial geology data (Cardwell and others, 1968). The larger buffer distance was used if carbonate rocks were present in greater than 50 percent of a 50-meter well buffer. Most of the wells, 289, are completed in noncarbonate rocks, whereas 35 wells are completed in carbonate rocks. One lithologic unit is present in the buffer zone for 223 wells, two lithologic units for 82 wells, three lithologic units for 16 wells, and four lithologic units for 3 wells.

The land-use/land-cover data used to calculate percent of land cover is from the National Land Cover Dataset of 2001 (NLCD2001) (Multiple Resolution Land Characteristics Consortium, 2007). The zone of influence from land cover for wells in the Appalachian Plateaus of West Virginia is fairly constrained as a result of relatively short and limited groundwater flow paths (McAuley and Kozar, 2006). Thus, land-cover data from the NLCD2001 was chosen for a 100-meter-radius buffer zone around each well sampled, with each land cover represented as a percentage of that 100-meter buffer zone. For each of the 14 land covers present in the well buffer zones, the maximum land cover ranges from 24 percent to 100 percent. The median for each land cover ranges from 0 percent to 29 percent; only developed open space (16 percent) and forested areas ( 29 percent) have medians greater than zero. This analysis demonstrates that the land cover around the sampled wells tends to be fairly heterogeneous, biased slightly towards developed open space and forested land covers.

Population density is a measure of approximately how many people per square mile live near each well. This analysis used block-group population density (U.S. Census Bureau, 2002) within a 100-meter buffer zone around each of the 
wells. For each 100-meter buffer, a weighted average population density was calculated by multiplying the population density for each block group that intersects the buffer by its corresponding area within the buffer, summing the resulting buffer block-group populations, and dividing by the buffer zone. Buffer population densities for the wells range from 4 to 3,798 people per square mile, with a median of 34 people per square mile and a standard deviation of 437 people per square mile.

The topographic setting of each well is a qualitative measure based on the steepness of or near the site as described in field notes and a well's location on Digital Raster Graphics (DRGs) of USGS Topographic Maps at the 1:24,000 scale. Three categories are defined — valley, hillside, or hilltop. Some ambiguity exists in this qualitative measure, especially in the karst landscape of the Eastern Panhandle of West Virginia. Most of the wells in this study are found in valley settings (208), with hilltop being the next most common (87) and hillside settings the least common (29).

Physiographic province and section were generated for each well by intersecting the point representing the well with physiographic data at the 1:7,000,000 scale (U.S. Geological Survey, 1998), which is based on the work of Fenneman and Johnson (1946). The physiographic provinces are defined by strong similarities in topography and geology. The Appalachian Physiographic Province covers about 83 percent of West Virginia; 73 percent or 238 of the sampled wells are located in this physiographic province. Of these, 22 wells are in the Allegheny Mountain Section, and 216 are in the Kanawha Section. All 85 Valley and Ridge Physiographic Province wells are located in the Middle Section. The Blue Ridge Physiographic Province covers a very small territory within West Virginia, and only two wells are located in its Northern Section.

\section{Wells Representing Unconsolidated Alluvial Aquifers}

In West Virginia, alluvial aquifers of Quaternary age occur in river valleys of the Appalachian Plateaus and Valley and Ridge Physiographic provinces. In the Appalachian Plateaus, the greatest extent of alluvial aquifer is found in the Ohio River Valley. Other Appalachian Plateaus alluvial aquifers are the Kanawha River Valley, Monongahela River Valley, and Teays Valley aquifers. Smaller, isolated alluvial aquifers also occur in the Appalachian Plateaus. In the Valley and Ridge Physiographic Province, alluvial aquifers are found in the South Branch Potomac River Valley, the Greenbrier River Valley, and along several Potomac River Basin tributaries.

Rivers have and continue to serve as transportation corridors. This use led to river valleys, in which alluvial aquifers are found, being early centers of settlement in West Virginia. Today, eight of West Virginia's nine cities with populations greater than 15,000 (U.S. Census Bureau, 2002) and their associated industrial land uses are at least partly located in alluvial settings. Additionally, much of the agricultural activities in
West Virginia's Appalachian Plateaus occur within alluvial river valleys.

A total of 49 alluvial aquifer wells were sampled in West Virginia. Of these, 40 sampled alluvial wells were in the Appalachian Plateaus Physiographic Province and 35 of the sampled alluvial wells were in the Ohio River Valley (table 1). Of the remaining sampled Appalachian Plateaus alluvial wells, three were in Kanawha River Valley alluvial aquifers and one each in alluvial aquifers of the Little Kanawha River and Meadow River Valleys. Nine alluvial aquifer wells were sampled in the Valley and Ridge Physiographic Province, seven in the Potomac River Basin, and two in the Greenbrier River Valley.

\section{Wells Representing Consolidated Bedrock Aquifers}

Consolidated bedrock aquifers are the most common type of aquifer in West Virginia and, therefore, account for an overwhelming majority, 275 of 324, of the wells sampled (table 1). Wells in bedrock aquifers were sampled in all three of West Virginia's Physiographic Provinces. The aquifers range in age from Permian aquifers, the youngest, to Cambrian aquifers, the oldest.

Permian aquifers are found in northwestern West Virginia in the Appalachian Plateaus Physiographic Province. Land cover in areas of Permian lithology is, as is true for much of West Virginia, predominantly forest. Land uses include oil and natural gas production, as well as coal mining. Permian aquifers are primarily nearly horizontal layers of shale with sandstone, limestone, and coal (Kozar and Brown, 1995). A total of 19 wells were sampled in Permian aquifers. All Permian wells are in areas where sandstone is the dominant lithology. Of the Permian wells, 16 are in valley settings, and 3 are on hillsides.

Pennsylvanian aquifers cover a greater portion of West Virginia than aquifers of other ages. Pennsyslvanian-aged geologies, all within the Appalachian Plateaus Physiographic Province, include much of West Virginia's extensive coal beds. The Pennsylvanian aquifers are nearly horizontal sandstone with shale, siltstone, coal, and limestone (Kozar and Brown, 1995). More Pennsylvanian-aquifer wells were sampled, 142, than any other age class of aquifer. The Pennsylvanian aquifers is the only environmental setting in which hilltop wells were more numerous than other topographic settings. Pennsylvanian-aquifer wells were sampled in both sandstone- and shaledominated areas. Of the 106 Pennsylvanian-aquifer wells in sandstone-dominated areas, 57 were in hilltop settings, 11 on hillsides, and 38 in valleys. Hilltop settings were more numerous for the 36 wells located in shale-dominated areas as well, with 24 wells in hilltop settings, three on hillsides, and nine sampled wells in valleys.

Mississippian aquifers are primarily found in southeast West Virginia and straddle the transition between the Appalachian Plateaus and Valley and Ridge Physiographic Provinces. The Mississippian aquifers are "moderately folded, predominantly sandstone and limestone with shale" (Kozar 
Table 1. Aquifer settings represented in the design of the ambient groundwater water-quality network

\begin{tabular}{|c|c|c|}
\hline Aquifer/setting & Lithology & Number of wells \\
\hline \multicolumn{3}{|c|}{ Quaternary (49 wells) } \\
\hline Ohio River Valley & Alluvium & 35 \\
\hline Kanawha River Valley & Alluvium & 3 \\
\hline Other Appalchian Plateaus valleys & Alluvium & 2 \\
\hline South Branch Potomac River Valley & Alluvium & 3 \\
\hline Greenbrier River Valley & Alluvium & 2 \\
\hline Other Valley and Ridge valleys & Alluvium & 4 \\
\hline \multicolumn{3}{|c|}{$\begin{array}{l}\text { Permian (19 wells) } \\
\end{array}$} \\
\hline Appalchian Plateaus hillside & Sandstone & 3 \\
\hline Appalchian Plateaus valley & Sandstone & 16 \\
\hline \multicolumn{3}{|c|}{ Pennsylvanian (142 wells) } \\
\hline Appalchian Plateaus hilltop & Sandstone & 57 \\
\hline Appalchian Plateaus hillside & Sandstone & 11 \\
\hline Appalchian Plateaus valley & Sandstone & 38 \\
\hline Appalchian Plateaus hilltop & Shale & 24 \\
\hline Appalchian Plateaus hillside & Shale & 3 \\
\hline Appalchian Plateaus valley & Shale & 9 \\
\hline \multicolumn{3}{|c|}{ Mississippian (45 wells) } \\
\hline Appalchian Plateaus hilltop & Limestone & 3 \\
\hline Appalchian Plateaus hillside & Limestone & 2 \\
\hline Appalchian Plateaus valley & Limestone & 10 \\
\hline Appalchian Plateaus hillside & Sandstone & 1 \\
\hline Appalchian Plateaus valley & Sandstone & 4 \\
\hline Appalchian Plateaus hilltop & Shale & 1 \\
\hline Appalchian Plateaus hillside & Shale & 4 \\
\hline Appalchian Plateaus valley & Shale & 9 \\
\hline Appalchian Plateaus hillside & Shale/sandstone & 2 \\
\hline Appalchian Plateaus valley & Shale/sandstone & 8 \\
\hline Valley and Ridge hillside & Sandstone & 1 \\
\hline \multicolumn{3}{|c|}{ Devonian (41 wells) } \\
\hline Appalchian Plateaus valley & Shale & 6 \\
\hline Valley and Ridge hillside & Limestone & 1 \\
\hline Valley and Ridge hillside & Sandstone & 1 \\
\hline Valley and Ridge hillside & Sandstone/limestone & 2 \\
\hline Valley and Ridge valley & Sandstone/limestone & 1 \\
\hline Valley and Ridge hilltop & Shale & 6 \\
\hline Valley and Ridge hillside & Shale & 10 \\
\hline Valley and Ridge valley & Shale & 14 \\
\hline \multicolumn{3}{|c|}{ Silurian (8 wells) } \\
\hline Valley and Ridge hillside & Limestone & 3 \\
\hline Valley and Ridge valley & Limestone & 2 \\
\hline Valley and Ridge hilltop & Sandstone & 1 \\
\hline Valley and Ridge hillside & Sandstone & 2 \\
\hline \multicolumn{3}{|c|}{ Ordovician (9 wells) } \\
\hline Valley and Ridge hillside & Limestone & 1 \\
\hline Valley and Ridge valley & Limestone & 6 \\
\hline Valley and Ridge hillside & Shale & 1 \\
\hline Valley and Ridge valley & Shale & 1 \\
\hline \multicolumn{3}{|c|}{ Cambrian (11 wells) } \\
\hline Blue Ridge hillside & Phyllite & 1 \\
\hline Blue Ridge hillside & Quartzite & 1 \\
\hline Valley and Ridge hillside & Dolostone & 1 \\
\hline Valley and Ridge hilltop & Limestone & 3 \\
\hline Valley and Ridge valley & Limestone & 2 \\
\hline Valley and Ridge hillside & Shale/sandstone & 2 \\
\hline Valley and Ridge valley & Shale/sandstone & 1 \\
\hline
\end{tabular}


and Brown, 1995), in other words, a more complex setting than either the Pennsylvanian or Permian aquifers. Land cover is predominantly forest with areas of agriculture, especially in the Greenbrier River Valley and its surrounding karst terranes. The 45 sampled wells in Mississippian aquifers comprise 11 combinations of physiography, lithology, and topography. Of the 45 wells, 44 are in the Appalachian Plateaus Province and only one in the Valley and Ridge Province. The 44 Appalachian Plateau wells consisted of 15 wells in limestone, 10 of which are in valley settings, 2 on hillsides, and 3 on hilltops; 5 in sandstone, 4 in valleys and 1 on a hillside; 14 in shale, 9 in valleys, 4 on hillsides, and 1 on a hilltop; and 10 wells in areas of mixed shale/sandstone aquifers, 8 in valleys and 2 on hillsides.

The Devonian aquifers are primarily in the Valley and Ridge Physiographic Province of West Virginia's Eastern Panhandle and along the State's eastern boundary with Virginia. However, a section of Devonian aquifers are in the Appalachian Plateaus Province in northeast West Virginia. Forested areas are the dominant land cover, with agricultural practices taking place in the valleys. Kozar and Brown (1995) described Devonian aquifers in West Virginia as ranging from "nearly horizontal" to "very folded," depending on geologic formation or group. Lithology of Devonian aquifers also varies widely, with some formations dominated by shale and siltstone and other formations dominated by limestone and sandstone. Forty-one wells tapping Devonian aquifers were sampled, 35 in the Valley and Ridge Province and 6 in the Appalachian Plateaus. Of the 35 Valley and Ridge wells, 30 were in shaledominated areas, 14 in valleys, 10 on hillsides, and 6 on hilltops; 3 were in areas with sandstone/limestone aquifers, 1 in a valley and the other 2 on hillsides; and one well each in areas of limestone aquifers and sandstone aquifers, both located on hillsides. The six wells located in the Appalachian Plateaus Province all tapped shale aquifers in valley settings.

In West Virginia, Silurian aquifers occur in the Valley and Ridge Province and primarily in the Eastern Panhandle, usually in narrow bands within areas dominated by Devonianaged rocks. Typically, Silurian aquifers consist of highly folded limestone, sandstone, and shale (Kozar and Brown, 1995). Land cover and land use are similar to those in the surrounding Devonian-dominated areas. Samples were collected from eight Silurian aquifer wells, three in hillside limestone settings, two in limestone-dominated valleys, two in sandstone hillsides, and one on a sandstone-dominated hilltop.

The Ordovician aquifers of West Virginia are in the Valley and Ridge Province, with the greatest extent of Ordovician lithology found in the easternmost portion of the Eastern Panhandle. West Virginia's Ordovician aquifers include karst terranes, these being most common in the State's Eastern Panhandle. Land uses in this portion of West Virginia are dominated by agriculture but this area is also experiencing rapid residential development. The Ordovician aquifers of West Virginia consist of highly folded beds of limestone, shale and sandstone (Kozar and Brown, 1995). Nine wells in Ordovician aquifers were samples, six in limestone valley settings, one on a limestone hillside, one shale hillside, and one in a shale valley setting.

The oldest aquifers in West Virginia are the Cambrian aquifers, located in the easternmost part of the State. West Virginia's Cambrian aquifers occur in both the Valley and Ridge and the Blue Ridge Provinces. Land cover in the Valley and Ridge portion of Cambrian lithology is similar to land cover in areas of Ordovician lithology. However, forest land cover dominated the Blue Ridge Province portion of Cambrian lithology. The Cambrian aquifers are highly folded and dominated by limestone or shale and sandstone (Kozar and Brown, 1995). Water was collected from 11 Cambrian-aquifer wells, 9 in the Valley and Ridge Province and 2 in the Blue Ridge Province. Environmental settings for Valley and Ridge Province wells included three wells in limestone hilltop settings, two wells in limestone valley settings, two wells in shale and sandstone hillside settings, and one well each in shaleand-sandstone valley and dolostone hillside settings. Both of the Blue Ridge Province wells are in hillside settings, one located in an area dominated by phyllite and the other in an area dominated by quartzite.

\section{Distribution of Wells among Environmental Settings}

The distribution of samples among the environmental settings, especially combinations of consolidated or unconsolidated aquifers and the geologic age of the aquifer, is uneven (table 2). Unconsolidated alluvial aquifers of Quaternary age represent less than 3 percent of the total area of West Virginia, yet more than 15 percent of all samples were collected in this setting. Similarly, Cambrian bedrock aquifers represent less than 1 percent of West Virginia's total area, yet more than 3 percent of all samples were from this setting. In contrast, Permian bedrock aquifers represent more than 20 percent of West Virginia; however, less than 6 percent of all samples were collected in this environmental setting. These disparities in sampling rates among environmental settings were largely driven by the distribution of population which is a primary factor in the distribution of wells.

\section{Well Sampling}

Groundwater samples were collected during the late spring and summer months. Prior to sampling, wells were purged to remove stagnant water from the casings and ensure that representative water samples were collected from the target aquifer. A minimum of one casing volume was purged from most wells; high-use public-supply wells that did not require purging or very low-yielding wells that would not recover from purging were pumped until field measurements stabilized. Field measurements of characteristics, including dissolved oxygen, $\mathrm{pH}$, specific conductance, water temperature, and turbidity, were monitored during purging by using a multi-parameter water-quality meter, which was calibrated 
Table 2. The distribution of samples by geologic age of aquifer.

\begin{tabular}{lccccc}
\hline $\begin{array}{c}\text { Geologic age } \\
\text { of aquifer }\end{array}$ & $\begin{array}{c}\text { Area, in } \\
\text { square miles }\end{array}$ & $\begin{array}{c}\text { Percent of } \\
\text { total area }\end{array}$ & $\begin{array}{c}\text { Number of } \\
\text { samples }\end{array}$ & $\begin{array}{c}\text { Percent of } \\
\text { samples }\end{array}$ & $\begin{array}{c}\text { Samples per } \\
\text { square mile }\end{array}$ \\
\hline Cambrian & 228 & 0.9 & 11 & 3.4 & 0.048 \\
Ordovician & 381 & 1.6 & 9 & 2.8 & 0.024 \\
Silurian & 478 & 2.0 & 8 & 2.5 & 0.017 \\
Devonian & 3,473 & 14.3 & 41 & 12.7 & 0.012 \\
Mississippian & 2,611 & 10.8 & 45 & 13.9 & 0.017 \\
Pennsylvanian & 11,477 & 47.4 & 142 & 43.8 & 0.012 \\
Permian & 4,933 & 20.4 & 19 & 5.9 & 0.004 \\
Quaternary & 621 & 2.6 & 49 & 15.1 & 0.079 \\
\hline
\end{tabular}

daily. Water level was also monitored where possible. Sample tubing typically was connected to a $3 / 4-i n$. hose bib as close to the well head as possible, and pumps were kept on to prevent contamination from plumbing or back flow from holding tanks. Existing plumbing and well-casing materials included, but were not limited to, steel, galvanized steel, copper, polyvinyl chloride (PVC), and other plastics. The purging procedure prescribed was assumed to have prevented contamination from plumbing materials. Samples were collected after field measurements stabilized, according to standard USGS protocols for the collection of water-quality data (U.S. Geological Survey, 2006). To prevent environmental contamination, samples were typically collected and processed inside a mobile field laboratory or a portable chamber assembled near the well.

All samples were analyzed for field measurements, alkalinity, fecal indicator bacteria (fecal coliforms, total coliforms, and Escherichia coli), major ions, trace elements, nutrients, volatile organic compounds (VOCs), and Radon-222 (table 3). Field determinations, including field measurements, alkalinity, and biological indicators, were processed on site according to standard protocols (U.S. Geological Survey, 2006). Subsets of samples were collected and analyzed for pesticides or semivolatile organic compounds.

Samples were processed according to standard USGS protocol (Wilde and others, 2004). Samples for analysis of dissolved major ions were filtered at 0.45 micrometer. Trace element analyses were performed on unfiltered samples. Nutrient analyses were performed on both filtered and unfiltered samples. Samples were then shipped daily by overnight courier to USGS laboratories for analysis.

\section{Statistical Methods}

Descriptive and summary statistics were calculated using Spotfire S-PLUS 8.1 statistical and graphing software (TIBCO Software, Inc., 2008). Descriptive and summary statistics for censored data sets, those with values less than the reporting level, were calculated using the Regression on Order Statistics (ROS) and adjusted maximum likelihood estimation
(AMLE) techniques (TIBCO Software Inc., 2008). Statistics were not calculated for sample sets of less than 10 items. Kruskal-Wallace rank test or ANOVA were used, as appropriate, for comparisons of medians among groups. A Tukey's Honest-Significant-Difference post hoc test was used for multiple comparisons.

Relations among several variables were analyzed through Principal Components Analysis (PCA). Analysis of groundwater-quality data for geochemical processes was performed using the PCA routine in SAS (SAS Institute Inc., 1999). PCA of groundwater-quality and environmental-setting data was performed in S-PLUS.

\section{Quality Assurance}

Quality-assurance samples, blanks and replicates, were collected during each year of sampling. Blank samples are used to determine the extent to which sampling procedures may contaminate samples, thereby biasing analytical results. Replicate samples are used to determine the variability inherent in the collection and analysis of environmental samples. Together, blank and replicate samples can be used to characterize the accuracy and precision of water-quality data. All quality-assurance samples were collected and processed according to protocols described in the USGS National Field Manual for the Collection of Water-Quality Data (U.S. Geological Survey, 2006).

\section{Blank Samples}

Blank samples consist of water of known quality, certified to not contain the constituents of interest in concentrations greater than a stated level, completely or partially processed in the same manner as an environmental sample. Any departure of the blank sample's analytical results from the blank water's known quality is an indication of contamination through handling, collecting, or processing the sample. Equipment 
Table 3. Water-quality characteristics, major ions, metals, trace elements, nutrients, radon-222, and fecal indicator bacteria analyzed for in groundwater samples from the West Virginia ambient monitoring network, 1993-2008.

[RL, reporting limit; NA, not applicable; ${ }^{\circ} \mathrm{C}$, degrees Celsius; $\mu \mathrm{S} / \mathrm{cm}$, microsiemens per centimeter, $\mathrm{mm} / \mathrm{Hg}$, millimeters in mercury; $\mathrm{mg} / \mathrm{L}$, milligrams per liter; NTU, nephelometric turbidity units; $\mathrm{CaCO}_{3}$, calcium carbonate; $\mathrm{H}^{+}$, hydrogen ion; wf, filtered water sample; wu, unfiltered sample; inflect, inflectionpoint titration; recov, recoverable; $\mathrm{ANC}$, acid neutralizing capacity; ROE, residue on evaporation; $\mu \mathrm{g} / \mathrm{L}$, micrograms per liter; $\mathrm{N}$, nitrogen; $\mathrm{NH}_{4}^{+}$, ammonium; $\mathrm{NO}_{3}+\mathrm{NO}_{2}$, nitrate plus nitrite; $\mathrm{P}$, phosphorus; $\mathrm{pCi} / \mathrm{L}$, picocuries per liter; $\mathrm{M}-\mathrm{FC}$, fecal coliform membrane filtration procedure; MPN, most probable number; cfu, colony-forming unit; NA-MUG, nutrient agar-4-methylumbelliferyl-b-D-glucuronide; M-Endo, modified Endo's agar]

\begin{tabular}{|c|c|c|c|}
\hline Constituent or property & $\mathbf{R L}$ & Constituent & $\mathbf{R L}$ \\
\hline Water temperature, ${ }^{\circ} \mathrm{C}$ & NA & Arsenic, wu, $\mu \mathrm{g} / \mathrm{L}$ & $0.2-4$ \\
\hline $\mathrm{pH}$, standard units & NA & Barium, wu, recov $\mu \mathrm{g} / \mathrm{L}$ & 0.6 \\
\hline Specific conductance at $25^{\circ} \mathrm{C}, \mu \mathrm{S} / \mathrm{cm}$ & NA & Beryllium, wu, recov $\mu \mathrm{g} / \mathrm{L}$ & $0.4-1$ \\
\hline Air pressure, mm/Hg & NA & Cadmium, wu, $\mu \mathrm{g} / \mathrm{L}$ & $0.01-0.5$ \\
\hline Dissolved oxygen, mg/L & NA & Chromium, wu, recov $\mu \mathrm{g} / \mathrm{L}$ & $0.4-1$ \\
\hline Turbidity, NTU & NA & Iron, wu, recov $\mu \mathrm{g} / \mathrm{L}$ & $2-6$ \\
\hline Alkalinity, inflect, field $\mathrm{mg} / \mathrm{L} \mathrm{CaCO}_{3}$ & 1 & Lead, wu, recov $\mu \mathrm{g} / \mathrm{L}$ & $0.6-2$ \\
\hline Acidity, heated, $\mathrm{mg} / \mathrm{L}$ as $\mathrm{H}^{+}$ & 0.1 & Manganese, wu, recov $\mu \mathrm{g} / \mathrm{L}$ & $0.2-1$ \\
\hline Acidity, $\mathrm{mg} / \mathrm{L}$, as $\mathrm{CaCO}_{3}$ & 1 & Mercury, wu, recov $\mu \mathrm{g} / \mathrm{L}$ & $0.01-0.1$ \\
\hline Bicarbonate, mg/L & 1 & Nickel, wu, recov $\mu \mathrm{g} / \mathrm{L}$ & $0.12-1$ \\
\hline Carbonate, $\mathrm{mg} / \mathrm{L}$ & 1 & Selenium, wu, $\mu \mathrm{g} / \mathrm{L}$ & $0.08-4$ \\
\hline Calcium, wu, recov, mg/L & 0.04 & Thallium,wu, $\mu \mathrm{g} / \mathrm{L}$ & $0.08-2$ \\
\hline Magnesium, wu, recov, mg/L & 0.008 & Zinc, wu, recov $\mu \mathrm{g} / \mathrm{L}$ & $1-2$ \\
\hline Potassium, wu, recov, mg/L & 0.1 & Ammonia, $\mathrm{mg} / \mathrm{L}$ as $\mathrm{N}$ & $0.01-0.04$ \\
\hline Sodium, wu, recov, $\mathrm{mg} / \mathrm{L}$ & $0.24-0.05$ & Ammonia, mg/ $\mathrm{L} \mathrm{NH}_{4}^{+}$ & NA \\
\hline $\mathrm{ANC}, \mathrm{mg} / \mathrm{L}$ of $\mathrm{CaCO}_{3}$ & 5 & $\mathrm{NO}_{3}+\mathrm{NO}_{2}, \mathrm{mg} / \mathrm{L}$ as $\mathrm{N}$ & $0.02-0.06$ \\
\hline Bromide, wf, mg/L & $0.02-0.2$ & Nitrate, $\mathrm{mg} / \mathrm{L}$ as $\mathrm{N}$ & NA \\
\hline Chloride, wf, mg/L & 0.2 & Nitrite, $\mathrm{mg} / \mathrm{L}$ as $\mathrm{N}$ & $0.002-0.01$ \\
\hline Fluoride, wu, mg/L & $0.1-0.12$ & Total nitrogen, mg/L & 0.06 \\
\hline Fluoride, wf, mg/L & 0.1 & Orthophosphate, $\mathrm{mg} / \mathrm{L}$ as $\mathrm{P}$ & $0.006-0.03$ \\
\hline Sulfate, wf, mg/L & $0.07-0.9$ & Phosphorus, mg/L & $0.004-0.02$ \\
\hline Residue, $\mathrm{ROE}$ at $105^{\circ} \mathrm{C}, \mathrm{mg} / \mathrm{L}$ & 13 & Radon-222, pCi/L & $10-30$ \\
\hline Residue, $\mathrm{ROE}$ at $180^{\circ} \mathrm{C}, \mathrm{mg} / \mathrm{L}$ & 10 & E. coli, Colilert, MPN/100 mL & 1 \\
\hline Organic carbon, mg/L & $0.1-0.4$ & E. coli, NA-MUG, cfu/100 mL & 1 \\
\hline Aluminum, wu, recov $\mu \mathrm{g} / \mathrm{L}$ & $2-4$ & Fecal coliform, M-FC, cfu/ $100 \mathrm{~mL}$ & 1 \\
\hline \multirow[t]{2}{*}{ Antimony, wu, $\mu \mathrm{g} / \mathrm{L}$} & $0.1-1$ & Total coliform, Colilert, MPN/100 mL & 1 \\
\hline & & Total coliform, M-Endo, cfu/100 mL & 1 \\
\hline
\end{tabular}


and field blank samples were collected throughout the study period. Equipment blank samples, processed by pumping blank water through sampling equipment in a laboratory setting, were used to determine if either equipment or cleaning procedures were a potential source of contaminants. Field blank samples, pumped through sampling equipment at field sites prior to collection of an environmental sample, were used to identify possible additional sources of contamination in the sampling procedure. Types of blank water used in this study included inorganic blank water and pesticide-grade, nitrogenpurged VOC-free blank water; both blank-water types are certified by the USGS National Water Quality Laboratory.

Analysis of blank samples varied with blank purpose. Each year prior to sampling, an equipment blank sample was processed with inorganic blank water in the West Virginia Water Science Center laboratory. These blank samples were analyzed for major ions, metals, trace elements, and nutrients. Field blank samples were analyzed for the same suite of constituents. In addition, field blank samples of pesticide-grade, nitrogen-purged, VOC-free blank water were processed on site and analyzed for pesticides or VOC's.

In general, results of blank-sample analyses indicated that equipment cleaning and sampling procedures were sufficient to prevent sample contamination. However, some blank samples contained detectable concentrations of target analytes. These are discussed by analyte or analyte class in the following paragraphs.

Aluminum was detected in both blank samples from 1999, at concentrations of 4 and 7 micrograms per liter $(\mu \mathrm{g} / \mathrm{L})$. The majority of concentrations for environmental samples, 19 of 30, were below the higher blank concentration. Furthermore, the median aluminum concentration in environmental samples from 1999 was $5 \mu \mathrm{g} / \mathrm{L}$ and for all other sampling periods combined it was below detection levels that ranged from 2 to $4 \mu \mathrm{g} / \mathrm{L}$. It seems likely that analyses for aluminum for all environmental samples collected in 1999 were biased high; therefore, aluminum results for environmental samples collected during this period were excluded from the analysis of ambient groundwater data. Aluminum was not detected in blank samples from any other year.

Calcium was detected in three blank samples, one each from 1999, 2005, and 2006. The calcium detection in 1999 was $0.02 \mathrm{mg} / \mathrm{L}$, the laboratory reporting level for that year. The detection of calcium in blank samples from 2005 and 2006 were both estimated values, 0.02 and $0.03 \mathrm{mg} / \mathrm{L}$, respectively. The lowest concentration in any environmental sample was $0.7 \mathrm{mg} / \mathrm{L}$, and the median value for all environmental samples was $31.3 \mathrm{mg} / \mathrm{L}$. It is unlikely blank contamination significantly influenced the analysis of any environmental sample or the interpretation of the data.

Sodium was detected in a blank sample in 1999 at a concentration of $0.2 \mathrm{mg} / \mathrm{L}$, the laboratory reporting level. The lowest value in any environmental sample that year was $6.8 \mathrm{mg} / \mathrm{L}$. It is unlikely this low-level of sodium detected in one blank sample significantly influenced results for environmental samples collected during this year.

Ammonia was detected at the $0.01 \mathrm{mg} / \mathrm{L}$ laboratory reporting level in approximately 25 percent of all blank samples. The persistent detection of ammonia at the threshold of quantification indicates a persistent source of contamination. However, the mean concentration in environmental samples was an order of magnitude greater, $0.22 \mathrm{mg} / \mathrm{L}$. The low-level concentrations of ammonia detected in blank samples were not considered to have influenced the interpretation of nitrate and nitrite data, neither of which were detected in any blank sample. No other nutrient species, nitrogen or phosphorus, was detected in any blank sample.

Concentrations of pesticides were detected in only one blank sample analyzed for these compounds. Both deethylatrazine and prometon were detected in a blank sample collected in 2000. Deethylatrazine, an atrazine degradation product, was detected at an estimated concentration $0.002 \mu \mathrm{g} / \mathrm{L}$ and prometon was remarked with an "M" code, indicating the compound's presence had been verified but not quantified. This blank sample was collected following equipment cleaning after sampling a well where multiple pesticides were detected, including deethylatrazine and atrazine. The compounds detected in the blank sample may represent contamination remaining following cleaning. However, neither deethylatrazine nor prometon were detected in subsequent pesticides samples.

A detectable concentration of a target compound was found in only one VOC blank sample. Trichloromethane was detected in a blank sample from 2007 at a concentration of $0.6 \mu \mathrm{g} / \mathrm{L}$. Trichloromethane was detected in an environmental sample from the previous day, albeit at a lower concentration, $0.1 \mu \mathrm{g} / \mathrm{L}$. Trichloromethane was not detected in any of the next eight environmental samples collected. The detection of trichloromethane in this blank sample appears to be anomalous and did not affect results for any environmental samples.

\section{Replicate Samples}

Comparison of results among replicate samples can provide insight into the sources of variability that are inherent in sample collection, processing, and analysis. Sample collection protocols (U.S. Geological Survey, 2006) require that environmental samples be collected after three casing volumes are purged from the well and field measurements of water temperature, specific conductance, dissolved oxygen, $\mathrm{pH}$, and turbidity have stabilized. Once these criteria have been met it is assumed that the water being sampled is both representative of the aquifer and constant through the duration of sample collection and that any variability among the main sample and replicate sample is primarily attributable to sample processing and analysis (Koterba and others, 1995).

Variability for a replicate sample pair was quantified by calculating the relative percent difference (RPD) of 
the samples. The RPD was calculated using the following formula:

$$
\left(\frac{\left|R_{1}-R_{2}\right|}{\left(\frac{R_{1}+R_{2}}{2}\right)}\right) \times 100
$$

Where

$$
\begin{aligned}
& R_{1} \quad \begin{array}{l}
\text { is the concentration of the analyte in the first } \\
\text { replicate sample and }
\end{array} \\
& R_{2} \quad \begin{array}{l}
\text { is the concentration of the analyte in the } \\
\text { second replicate sample. }
\end{array}
\end{aligned}
$$

Generally, concentrations in replicate sample pairs differed by small amounts, typically less than 15 RPD. Many of the replicate sample pairs with RPDs greater than 15 were for comparisons of estimated values or for values very close to the reporting level, where a difference of the smallest reported increment of change is greater than 15 RPD and may be attributable to rounding error. However, some constituent replicate sample pairs that differed by more than 15 RPD that did not fit these criteria and are discussed by analyte below.

Three lead replicate sample pairs, two collected in 2006 and one collected in 2007, differed by more than 15 RPD, from 15.4 to 35.3 RPD. Laboratory quality-assurance data from the period when the two 2006 replicate sample pairs were analyzed indicate method spike recoveries, an indication of the ability to accurately measure a sample of known concentration, were greater than normal for this analytical run, perhaps contributing to increased sample variability. The difference in the 2007 replicate sample pair most likely reflects cumulative sample processing and analytical variability contributions.

Replicate chromium samples were generally in good agreement, with RPDs less than 15, with the exception of two replicate sample pairs collected in 2006. The chromium concentrations in these sample pairs, differing by 16 and 40 RPD, were reported using an interim reporting level that was subsequently increased to a level that resulted in these sample pairs being reported as either "less than" or "estimated" values.

Replicate nutrient samples were within acceptable ranges of differences. The only occurrences of RPDs greater than 15 was for very low-level concentrations, where the concentration in one replicate sample was below the reporting level and in the other sample was either minimally greater than the reporting level or an estimated value.

\section{Groundwater Quality In West Virginia}

Concentrations of water-quality constituents were compared to existing regulatory and non-regulatory water-quality criteria, either USEPA primary and secondary maximum contaminant levels (MCLs and SMCLs) (U.S. Environmental Protection Agency, 2009b) or health-based screening levels
(HBSLs; Toccalino and others, 2008). These criteria are applicable to finished drinking water, not the raw water samples collected for this study. These criteria are used to provide a benchmark against which water-quality characteristics and constituents are compared and may be useful for resource managers charged with protecting and managing drinkingwater resources. For example, the comparisons can provide an indication of when contaminant concentrations in ambient water resources may warrant further study or monitoring. The use of comparisons implies neither compliance nor non-compliance with drinking-water standards. The sample data for this study can be accessed through the USGS NWISWeb portal for West Virginia water-quality samples (http://waterdata. usgs.gov/wv/nwis/qw/).

\section{Water-Quality Characteristics}

Specific conductance and $\mathrm{pH}$ of groundwater provide a general indication of water quality and often bear a signature of the source aquifer. These characteristics also influence other chemical constituents present by affecting solubility, partitioning, and valence states. Although much of the variability of specific conductance and $\mathrm{pH}$ in groundwater is due to natural factors, anthropogenic activities, such as coal mining, also contribute to this variability (McAuley and Kozar, 2006).

\section{Specific Conductance}

Specific conductance, the ability of water to conduct an electrical current, is dependent upon the amount of dissolved ions present in the water. In this study, specific conductance ranged from 29 microsiemens per centimeter $(\mu \mathrm{S} / \mathrm{cm})$ to $2,610 \mu \mathrm{S} / \mathrm{cm}$ with a median value of $444 \mu \mathrm{S} / \mathrm{cm}$. The median value for this study closely agrees with a median value of $417 \mu \mathrm{S} / \mathrm{cm}$ for samples from 2,137 domestic wells in the principal aquifers of the United States (DeSimone, 2008). Median values for specific conductance did not differ greatly among the aquifers (fig. 2). In a comparison of sets of more than 10 samples, each set representing the geologic age of aquifers (Cambrian, Devonian, Mississippian, Pennsylvanian, Permian, and Quaternary), the median value for specific conductance was highest, $648 \mu \mathrm{S} / \mathrm{cm}$, for wells in Cambrian aquifers and lowest, $283 \mu \mathrm{S} / \mathrm{cm}$, for wells in Devonian aquifers.

$\mathrm{pH}$

The measure of acidity or alkalinity of a solution, $\mathrm{pH}$, plays an important role in the solubility of metals. The $\mathrm{pH}$ of samples collected in this study ranged from 4.2 to 10.0, with an overall median of 7.1. $\mathrm{pH}$ did not differ greatly with respect to geologic age, with the exception of Permian aquifers; median values of $\mathrm{pH}$ ranged from 6.9 in samples from Cambrian aquifers and Quaternary aquifers to about 8.4 in samples from Permian aquifers (fig. 3 ). The USEPA has established a SMCL for $\mathrm{pH}$. The SMCL is a recommendation, based on 


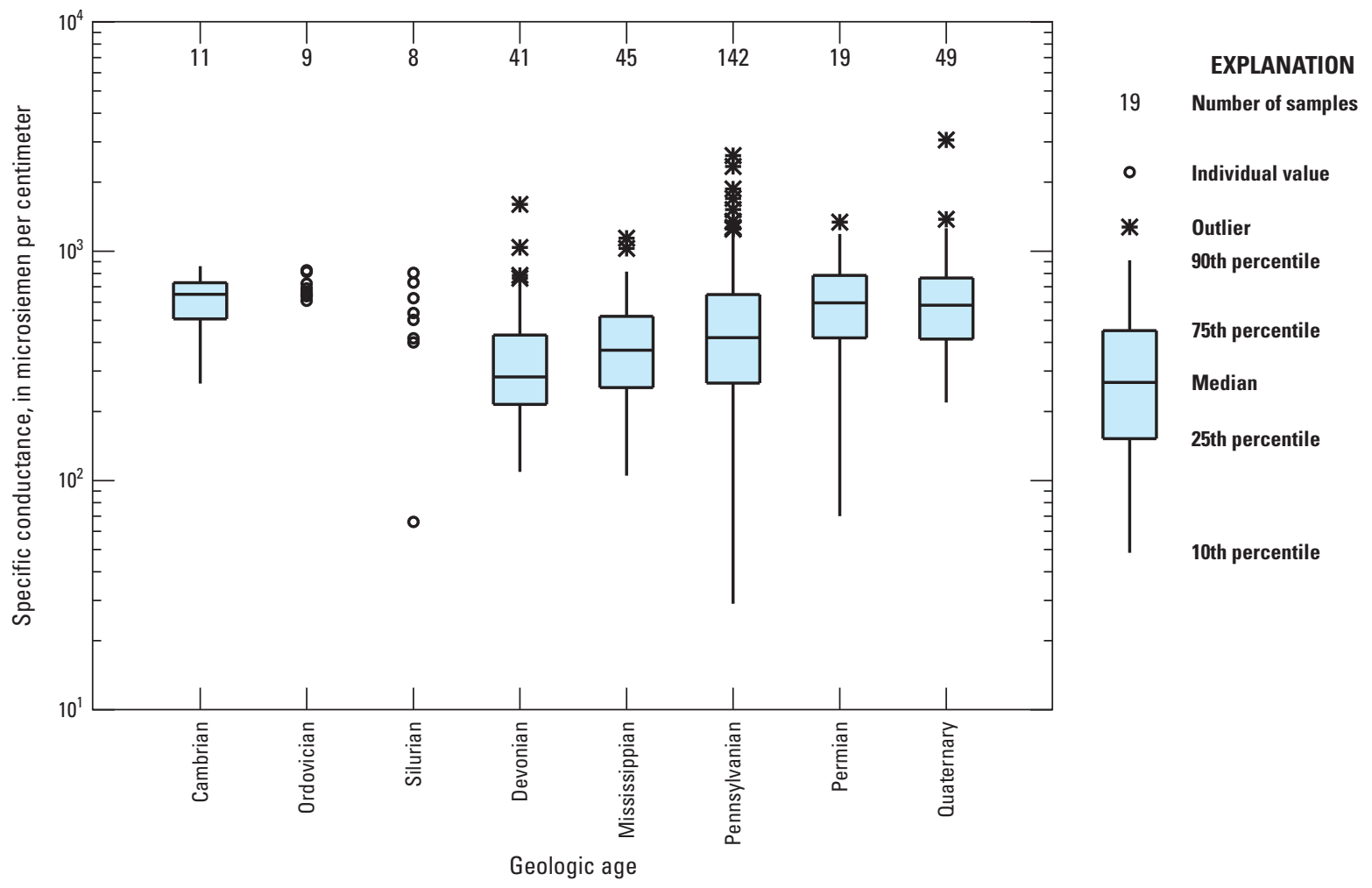

Figure 2. Distribution of specific conductance values in groundwater samples from the West Virginia ambient monitoring network, grouped by geologic age of the aquifers, 1993-2008.

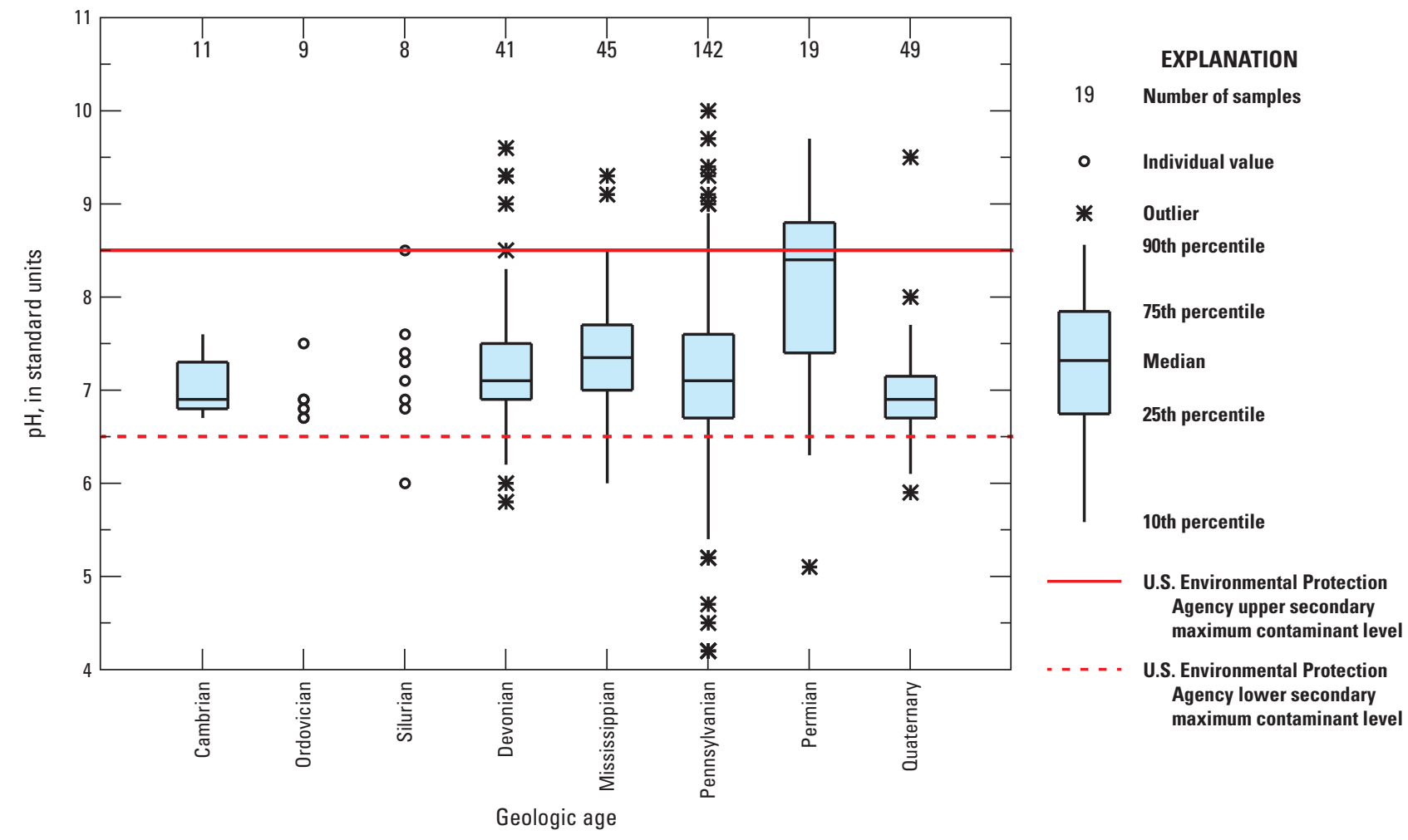

Figure 3. Distribution of $\mathrm{pH}$ in groundwater samples from the West Virginia ambient monitoring network, grouped by geologic age of the aquifers, 1993-2008. U.S. Environmental Protection Agency (2009b) recommended upper and lower values for the secondary maximum contaminant level are shown. 


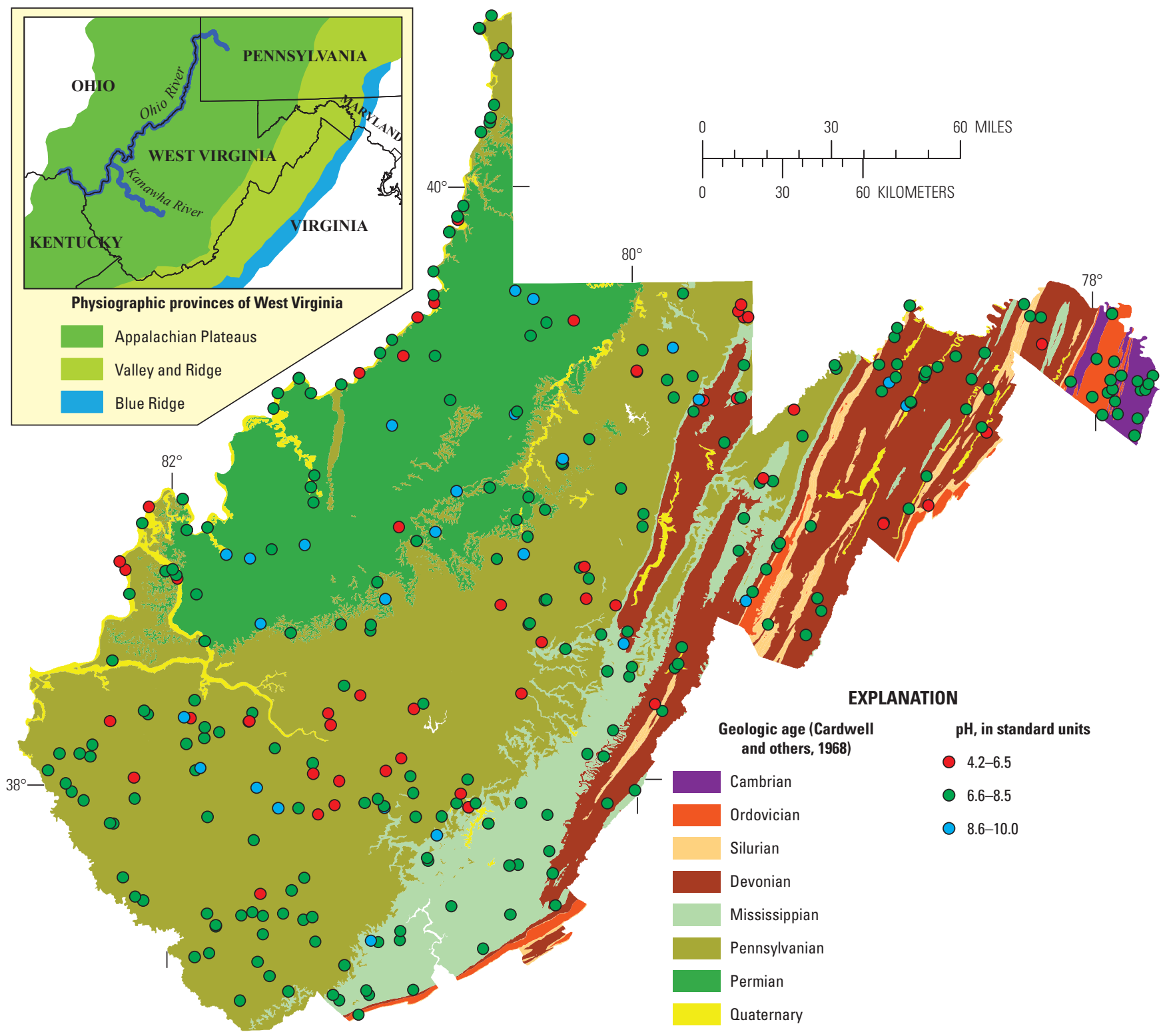

Figure 4. Distribution of $\mathrm{pH}$ values for all groundwater samples from the West Virginia ambient monitoring network, 1993-2008. 
aesthetic effects, primarily taste, that ideally $\mathrm{pH}$ would fall within the range of 6.5 to 8.5 (U.S. Environmental Protection Agency, 2009b). Most samples, 77 percent, fell within the USEPA recommended SMCL range (U.S. Environmental Protection Agency, 2009b) with 13 percent of samples falling below the recommended minimum of 6.5 and 10 percent exceeding the recommended maximum of 8.5 (fig. 4).

\section{Dissolved Oxygen and Temperature}

Dissolved oxygen concentration and water temperature were measured primarily to monitor stability of water-quality characteristics during well purging and to ensure that the well was adequately purged and the well bore contained only water from the surrounding aquifer at the time of sample collection.

Dissolved oxygen in groundwater is from recharge of the aquifer with oxygenated water. Over time, dissolved oxygen can be depleted due to reactions with oxidizable matter (Hem, 1986). However, dissolved oxygen concentrations in groundwater vary, in part due to availability of oxidizable matter, recharge rate, and residence time in the aquifer. In this study, dissolved oxygen concentrations ranged from less than $(<) 1 \mathrm{mg} / \mathrm{L}$ to $13 \mathrm{mg} / \mathrm{L}$, with a median concentration of
$<1 \mathrm{mg} / \mathrm{L}$. Dissolved oxygen concentrations did vary by geologic setting, with median concentrations less than $2 \mathrm{mg} / \mathrm{L}$ in all geologies, except those dominated by limestone, dolostone, or mixed limestone and sandstone surficial lithologies, where median concentrations were $5.5 \mathrm{mg} / \mathrm{L}, 5.8 \mathrm{mg} / \mathrm{L}$ (one sample only), and $4.9 \mathrm{mg} / \mathrm{L}$, respectively.

Water temperature ranged from $6.5^{\circ} \mathrm{C}$ to $21.5^{\circ} \mathrm{C}$, with a median for all samples of $13.8^{\circ} \mathrm{C}$. No pattern in differences among environmental settings was noted.

\section{Major lons}

The major ions calcium, magnesium, potassium, sodium, bicarbonate from field alkalinity, chloride, and sulfate exert a strong influence on water quality and geochemical processes.

\section{Calcium}

Calcium $(\mathrm{Ca})$ is the most common alkaline-earth element and a major component of many common minerals (Hem, 1985). Calcium concentrations ranged from $0.7 \mathrm{mg} / \mathrm{L}$ to $286 \mathrm{mg} / \mathrm{L}$ (fig. 5, table 4). Samples from wells that tap Cambrian aquifers had the highest median $\mathrm{Ca}$ concentration

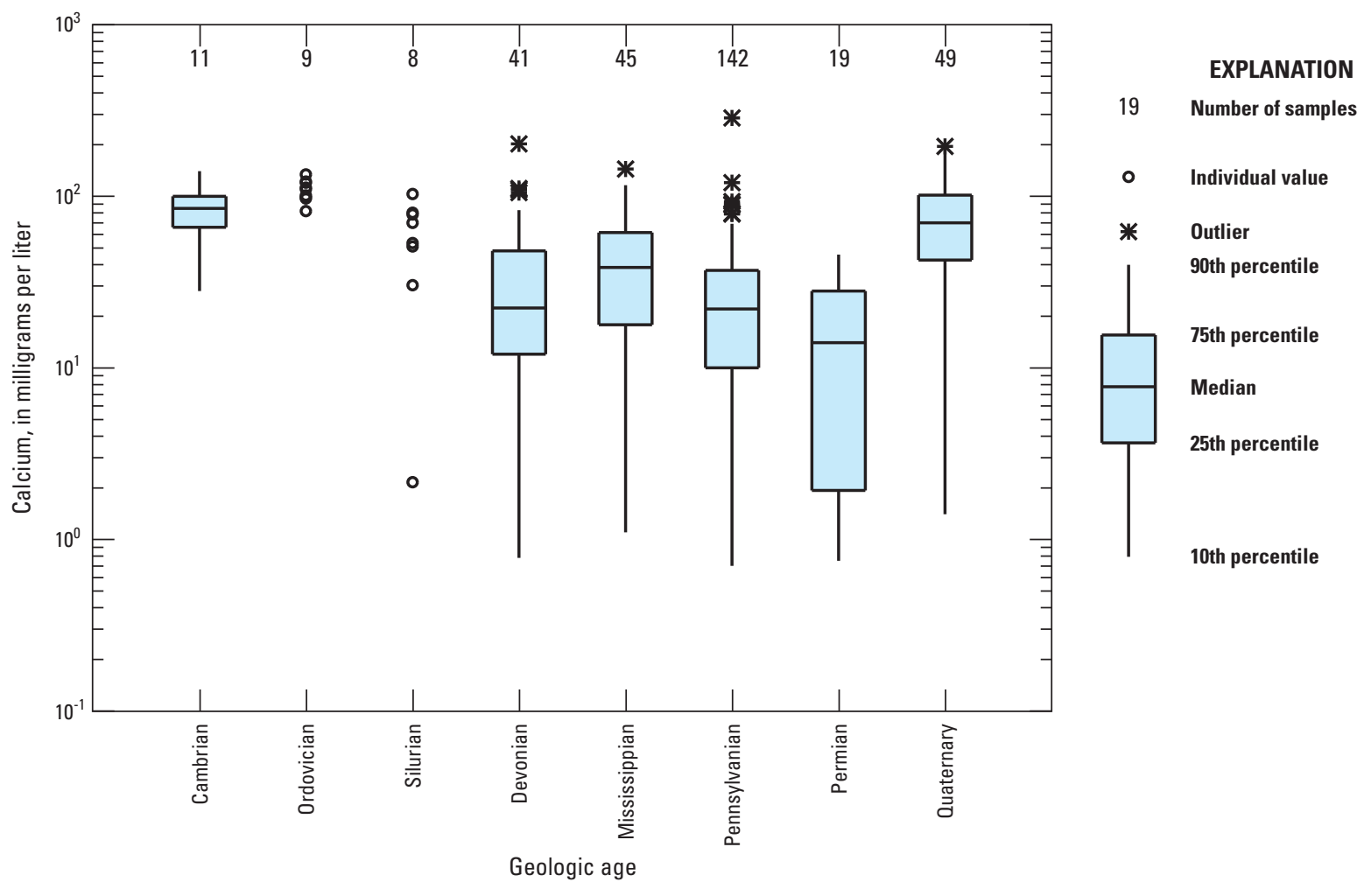

Figure 5. Distribution of calcium concentrations in groundwater samples from the West Virginia ambient monitoring network, grouped by geologic age of the aquifers, 1993-2008. 
Table 4. Statistical summary of major ions for groundwater samples from West Virginia ambient monitoring network, 1993-2008.

[mg/L, milligram per liter; SMCL, secondary maximum contaminant level (U.S. Environmental Protection Agency, 2009b); <, less than; NA, not applicable; ,-- not reported]

\begin{tabular}{lccccccc}
\hline \multicolumn{1}{c}{ Major ions } & $\begin{array}{c}\text { Reporting } \\
\text { units }\end{array}$ & $\begin{array}{c}\text { Method } \\
\text { reporting } \\
\text { level }\end{array}$ & $\begin{array}{c}\text { Minimum } \\
\text { concentration }\end{array}$ & $\begin{array}{c}\text { Maximum } \\
\text { concentration }\end{array}$ & $\begin{array}{c}\text { Median } \\
\text { value }\end{array}$ & $\begin{array}{c}\text { SMCL } \\
\text { SMCL value }\end{array}$ & $\begin{array}{c}\text { Samples } \\
\text { exceeding } \\
\text { SMCL }\end{array}$ \\
\hline Calcium, unfiltered, recoverable & $\mathrm{mg} / \mathrm{L}$ & 0.04 & 0.70 & 286 & 31.3 & $\mathrm{NA}$ & -- \\
Magnesium, unfiltered, recoverable & $\mathrm{mg} / \mathrm{L}$ & 0.08 & 0.10 & 68.3 & 6.4 & $\mathrm{NA}$ & -- \\
Potassium, unfiltered, recoverable & $\mathrm{mg} / \mathrm{L}$ & 0.08 & $<0.1$ & 16 & 1.4 & $\mathrm{NA}$ & -- \\
Sodium, unfiltered, recoverable & $\mathrm{mg} / \mathrm{L}$ & $0.1-0.24$ & 0.20 & 475 & 27 & $\mathrm{NA}$ & -- \\
Bicarbonate, filtered & $\mathrm{mg} / \mathrm{L}$ & 1 & $<1$ & 829 & 191 & $\mathrm{NA}$ & -- \\
Chloride, filtered & $\mathrm{mg} / \mathrm{L}$ & 0.20 & $<0.2$ & 736 & 16.6 & 250 & 4 \\
Sulfate, filtered & $\mathrm{mg} / \mathrm{L}$ & $0.07-0.9$ & $<0.07$ & 767 & 14.7 & 250 & 9 \\
\hline
\end{tabular}

$(85 \mathrm{mg} / \mathrm{L})$. The lowest median Ca concentration was in samples from wells in Permian aquifers (median $14 \mathrm{mg} / \mathrm{L}$ ). The highest measured concentration, $286 \mathrm{mg} / \mathrm{L}$, was in a sample from a well in the Pennsylvanian-aged Monongahela Group aquifer.

\section{Magnesium}

Magnesium is similar to calcium in many aspects but differs significantly from calcium in geochemical behavior (Hem, 1985). Magnesium values for all samples ranged from $0.1 \mathrm{mg} / \mathrm{L}$ to $68.3 \mathrm{mg} / \mathrm{L}$ (fig. 6 ; table 4). Median values ranged from $2.7 \mathrm{mg} / \mathrm{L}$ for wells in Permian aquifers to $22 \mathrm{mg} / \mathrm{L}$ for wells in Cambrian aquifers.

\section{Potassium}

Potassium is an essential nutrient and is a limiting resource in some ecosystems. Overall, potassium concentrations ranged from values less than the reporting level of $0.08 \mathrm{mg} / \mathrm{L}$ (minimum value of $<0.1 \mathrm{mg} / \mathrm{L}$ ) to $16 \mathrm{mg} / \mathrm{L}$ with a median value of $1.4 \mathrm{mg} / \mathrm{L}$ (table 4 ). The highest median value for potassium was $1.80 \mathrm{mg} / \mathrm{L}$ for samples from Cambrian aquifers (fig. 7). Wells completed in Mississippian aquifers had the lowest median potassium value, $0.71 \mathrm{mg} / \mathrm{L}$.

\section{Sodium}

Sodium is the most abundant alkali-metal (Hem, 1985). Sodium concentration varied greatly within and among wells representing aquifers of different geologic ages; concentrations in samples from Pennsylvanian aquifers span the entire range from $0.2 \mathrm{mg} / \mathrm{L}$ to $475 \mathrm{mg} / \mathrm{L}$ (fig. 8; table 4). The median sodium concentration was lowest in Cambrian aquifers $(6.39 \mathrm{mg} / \mathrm{L})$, and the median concentration of sodium was highest in Permian aquifers (130 mg/L).

\section{Bicarbonate from Field Alkalinity}

Dissolved inorganic carbon in groundwater is result of the dissolution of atmospheric and soil-zone carbon dioxide $\left(\mathrm{CO}_{2}\right)$, as well as reactions with carbonate rocks (Hem, 1985). This dissolved inorganic carbon as bicarbonate ions, carbonate ions, and free carbon dioxide can reach equilibria and constitute a buffer system that is resistant to changes in $\mathrm{pH}$ (Wetzel, 2001). The proportions of bicarbonate, carbonate, and free carbon dioxide in water is closely linked to $\mathrm{pH}$. Below a $\mathrm{pH}$ of about 4.3, only free carbon dioxide and carbonic acid exist. At a pH of approximately 4.3 bicarbonate increases and is the dominant form of dissolved inorganic carbon between pH 7 and $\mathrm{pH} 9$ (Wetzel, 2001). At a pH of approximately 8.3 the proportion of carbonate ions starts to increase, and at $\mathrm{pH}$ values greater than 9 carbonate becomes the dominant form of dissolved inorganic carbon.

Bicarbonate concentrations were determined by field titrations for alkalinity. Alkalinity is the capacity of water to neutralize an acid and is expressed in $\mathrm{mg} / \mathrm{L}$ of calcium carbonate $\left(\mathrm{CaCO}_{3}\right)$. Although noncarbonate species can contribute to alkalinity, Hem (1985) stated that with some rare exceptions "the alkalinity of natural waters can be assigned entirely to dissolved bicarbonate and carbonate without serious error."

The bicarbonate ion was the prevalent form of dissolved inorganic carbon in all samples. This is not surprising given the range of $\mathrm{pH}$ for all samples was from 4.1 to 10. Carbonate was detected in less than 3 percent of samples. Both the low and high bicarbonate concentrations for this study, less than 1 and $826 \mathrm{mg} / \mathrm{L}$, were measured in samples from wells in Pennsylvanian aquifers (fig. 9; table 4). Wells in Devonian aquifers had the lowest median bicarbonate, $144 \mathrm{mg} / \mathrm{L}$, of the geologic age classes. The highest median bicarbonate was measured in water samples from Cambrian aquifers and Ordivician aquifers, $354 \mathrm{mg} / \mathrm{L}$ and $356 \mathrm{mg} / \mathrm{L}$, respectively. Additionally, the greatest difference in median alkalinity was between sandstone and limestone settings. 


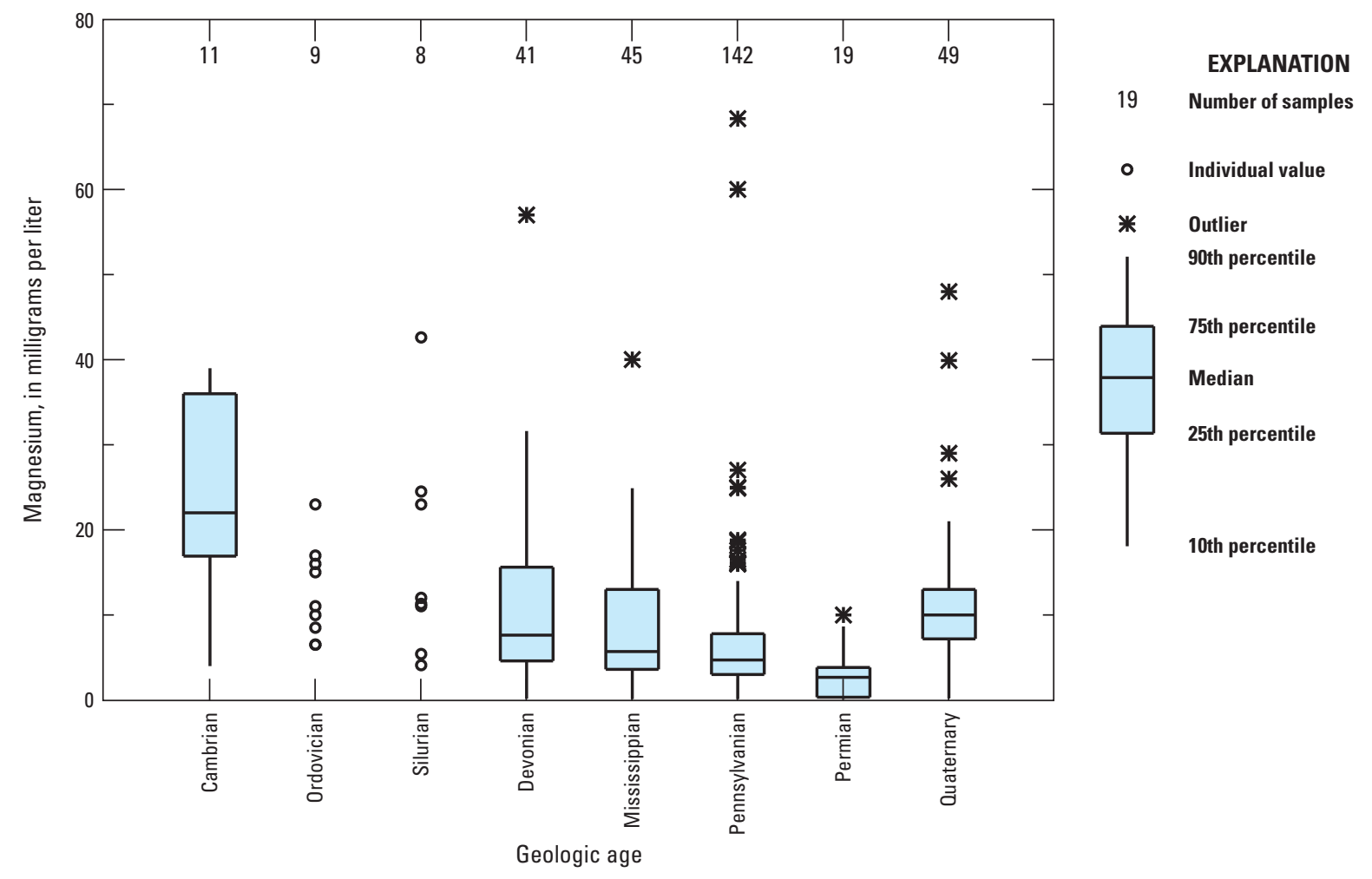

Figure 6. Distribution of magnesium concentrations in groundwater samples from the West Virginia ambient monitoring network, grouped by geologic age of the aquifers, 1993-2008.

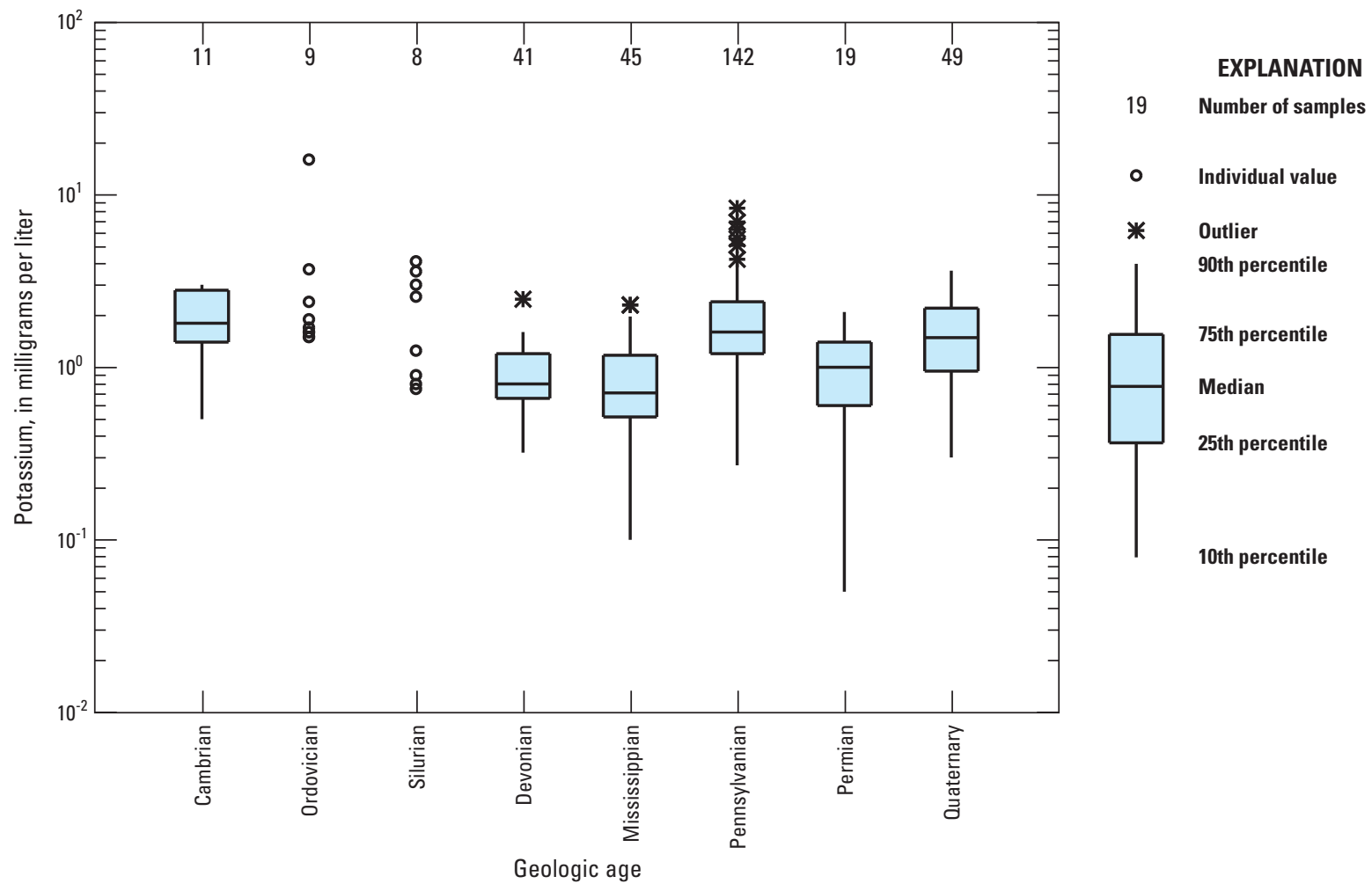

Figure 7. Distribution of potassium concentrations in groundwater samples from the West Virginia ambient monitoring network, grouped by geologic age of the aquifers, 1993-2008. 


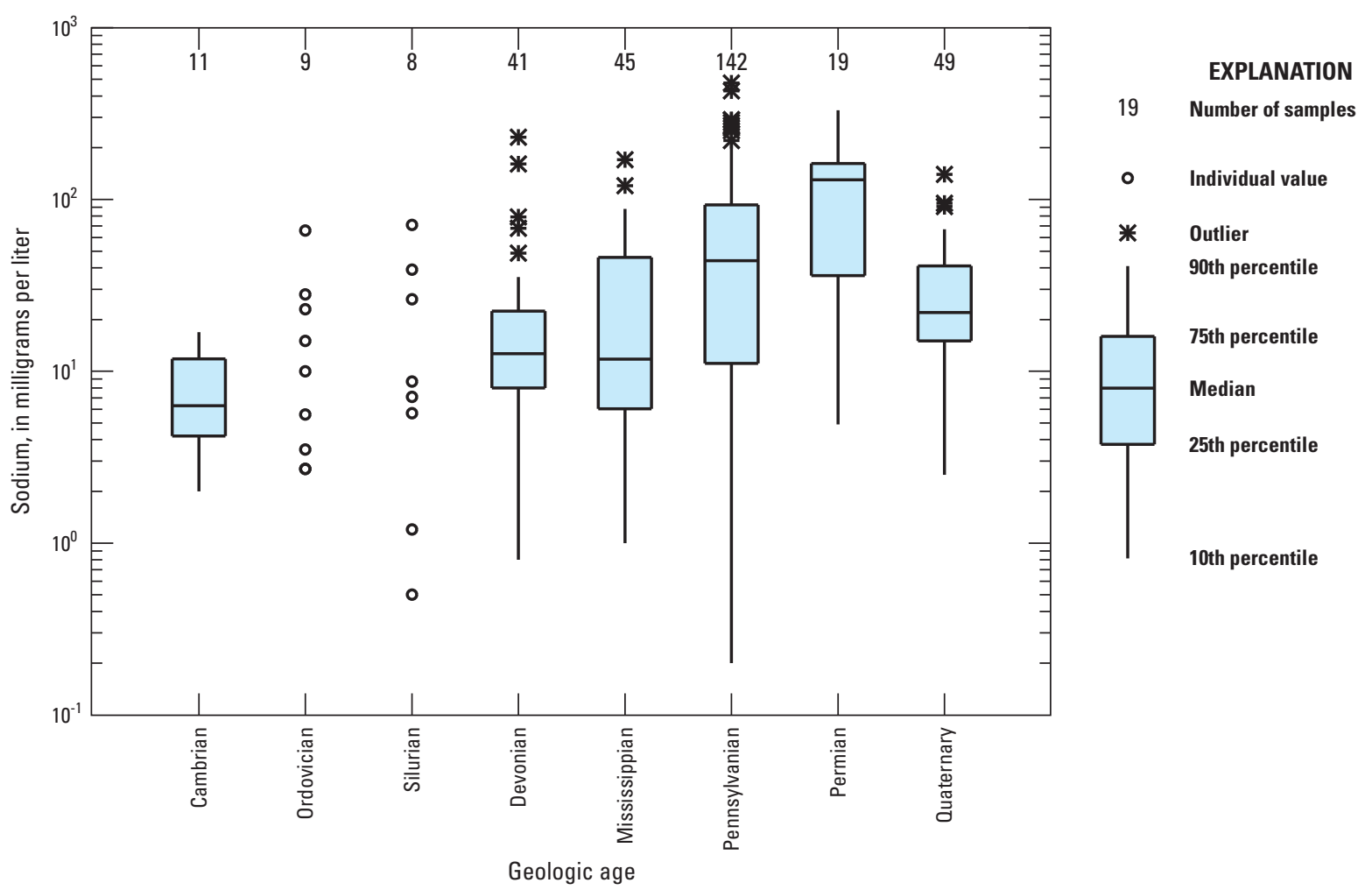

Figure 8. Distribution of sodium concentrations in groundwater samples from the West Virginia ambient monitoring network, grouped by geologic age of the aquifers, 1993-2008.

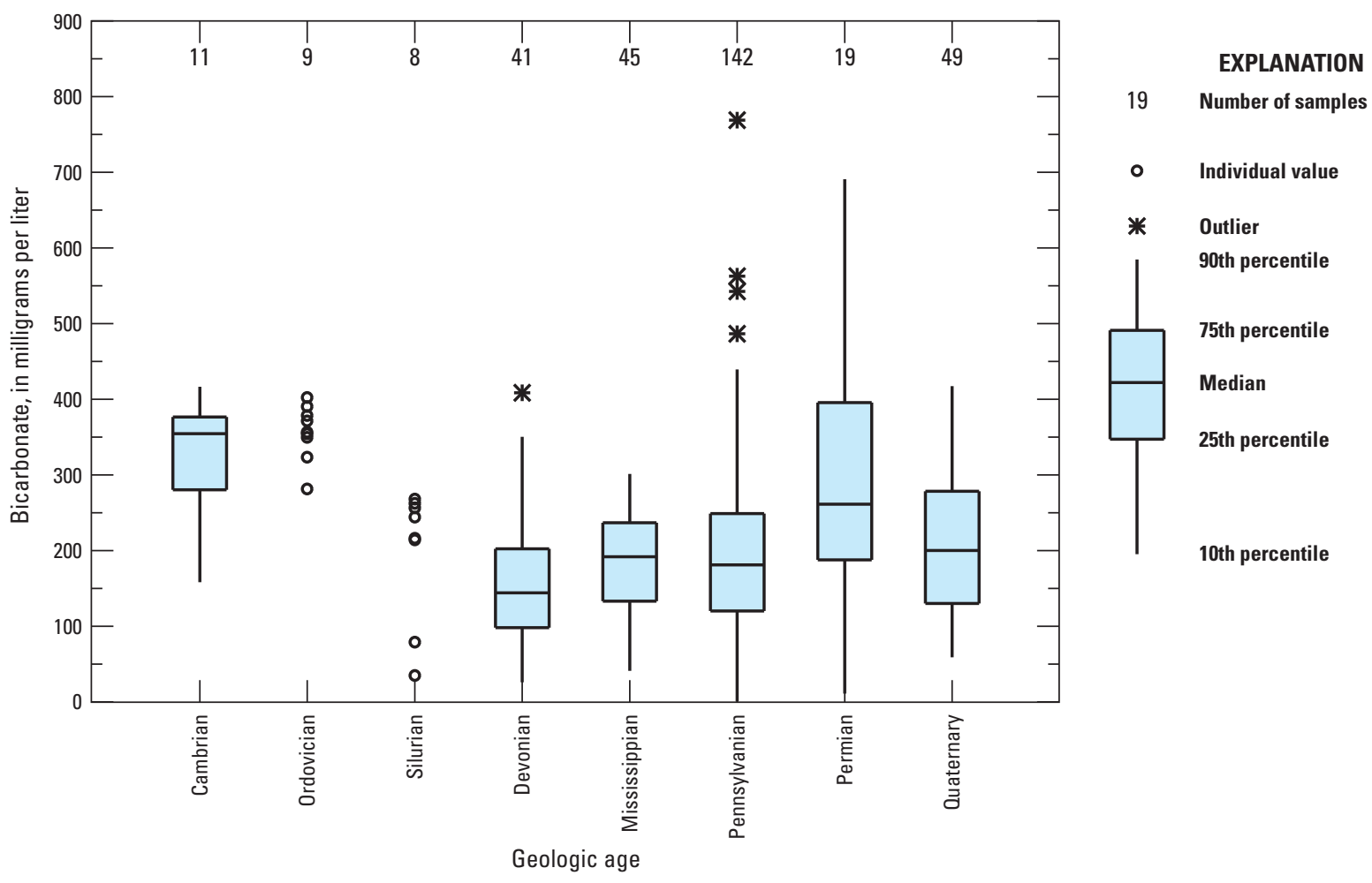

Figure 9. Distribution of bicarbonate in groundwater samples from the West Virginia ambient monitoring network, grouped by geologic age of the aquifers, 1993-2008. 


\section{Chloride}

Chloride, the most abundant halide (Hem, 1985), ranged in concentration from less than the $0.2 \mathrm{mg} / \mathrm{L}$ minimum reporting level to $736 \mathrm{mg} / \mathrm{L}$ with a median value of $16.6 \mathrm{mg} / \mathrm{L}$ (table 4). Most wells, 80 percent, had chloride values from $1.8 \mathrm{mg} / \mathrm{L}$ to $77 \mathrm{mg} / \mathrm{L}$. Median values, by geologic ages of aquifers, ranged from $6.6 \mathrm{mg} / \mathrm{L}$ for wells in Devonian aquifers to $28 \mathrm{mg} / \mathrm{L}$ for wells in Quaternary aquifers (fig. 10).

The SMCL for chloride is $250 \mathrm{mg} / \mathrm{L}$ (U.S. Environmental Protection Agency, 2009b). Samples from four wells exceeded this concentration. All four were from areas of Pennsylvanian aquifers.

\section{Sulfate}

In West Virginia pyrite-bearing rock formations are a major source of sulfate in groundwater. MacAuley and Kozar (2006) found groundwater sulfate concentrations to be increased in mined areas of West Virginia's Northern Appalachian Coal Basin.

Although sulfate concentrations ranged from less than a reporting level of $0.07 \mathrm{mg} / \mathrm{L}$ to $767 \mathrm{mg} / \mathrm{L}$ with a median value of $14.7 \mathrm{mg} / \mathrm{L}$ for all samples, most wells ( 80 percent) had sulfate concentrations of $0.3 \mathrm{mg} / \mathrm{L}$ to $86 \mathrm{mg} / \mathrm{L}$. Median sulfate concentrations varied widely by geologic age of the aquifers, from a low of $6.7 \mathrm{mg} / \mathrm{L}$ for wells in Pennsylvanian aquifers to $58.6 \mathrm{mg} / \mathrm{L}$ for wells in Quaternary aquifers (fig. 11). Sulfate concentrations exceeding the SMCL of $250 \mathrm{mg} / \mathrm{L}$ (U.S. Environmental Protection Agency, 2009b) were found in samples from nine wells (table 4).

\section{Water Types}

Natural waters can be classified by "water type" on the basis of major-ion composition. Water samples with a specific cation or anion constituting more than one-half the total cations or anions can be classified by water type, calcium carbonate type water, for example (Hem, 1985). However, waters in which no single cation or anion constitutes greater than one-half of the total cations or anions are classed as mixed-type waters (Hem, 1985). Samples from aquifers classified by geologic age typically reflect a signature characteristic of the rock type, although the rock-type signatures may overlap broadly. Calcium was the dominant cation in most samples from wells in Quaternary aquifers (fig. 12A); the dominant anion in most samples from Quaternary aquifers was bicarbonate with some samples having a sulfate or chloride

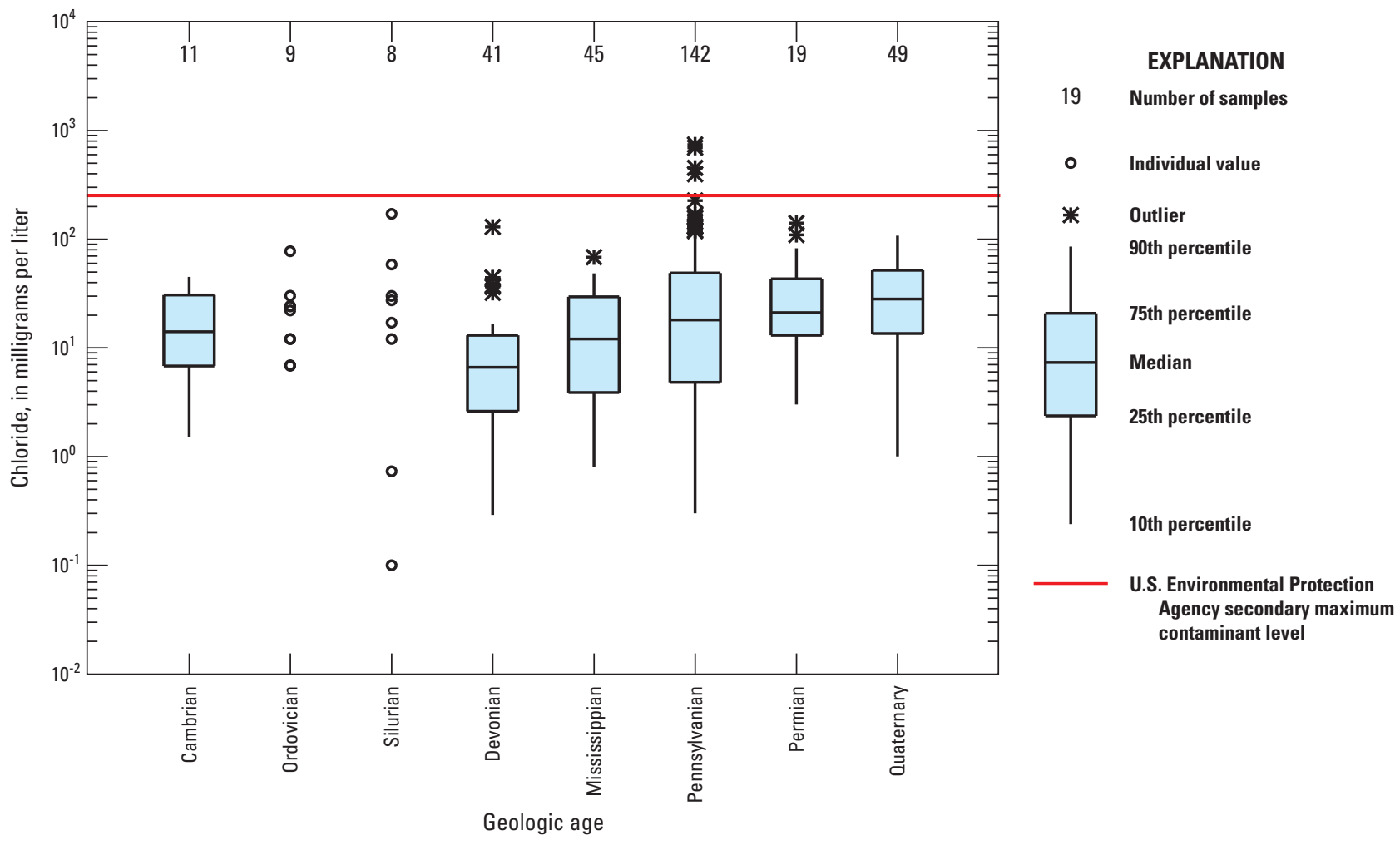

Figure 10. Distribution of chloride concentrations in groundwater samples from the West Virginia ambient monitoring network, grouped by geologic age of the aquifers, 1993-2008. U.S. Environmental Protection Agency (2009b) secondary maximum contaminant level of 250 milligrams per liter for finished drinking water is shown. 


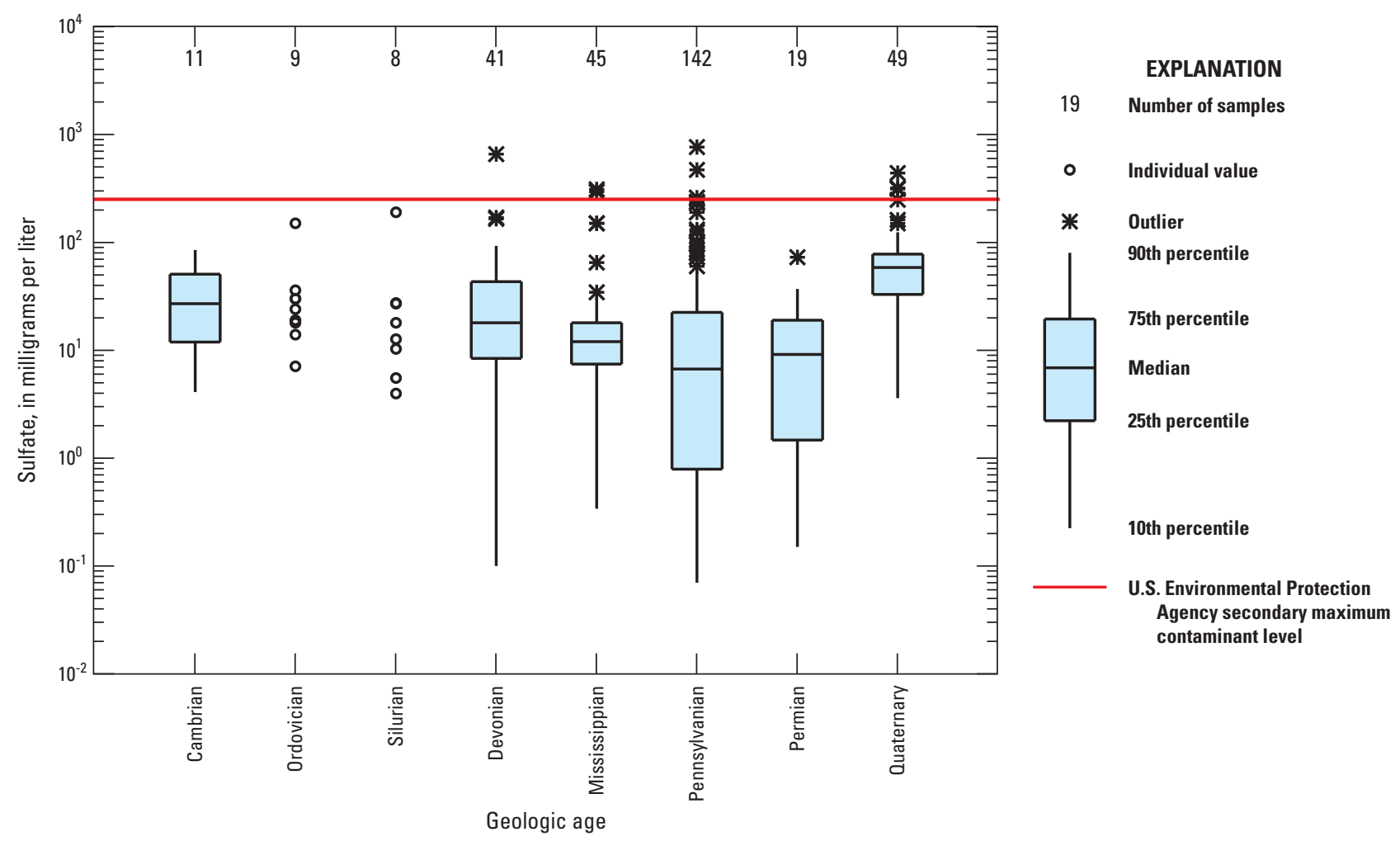

Figure 11. Distribution of sulfate concentrations in groundwater samples from the West Virginia ambient monitoring network, grouped by geologic age of the aquifers, 1993-2008. U.S. Environmental Protection Agency (2009b) secondary maximum contaminant level of 250 milligrams per liter for finished drinking water is shown.

signature. Samples from wells in Cambrian, Ordovician, and Silurian aquifers, which are predominantly limestone rocks in West Virginia, were almost uniformly a calcium bicarbonate type water (fig. 12B). Limestone is primarily calcite, which is $\mathrm{CaCO}_{3}(\mathrm{Hem}, 1985)$. Water types from wells in Devonian aquifers were typically either calcium bicarbonate or magnesium bicarbonate (fig. 12C). Samples from Mississippian aquifers were primarily calcium bicarbonate water with some sodium/ potassium carbonate water (fig. 12D). The strong calcium carbonate signature is likely due to the many Mississippian limestone formations present in West Virginia. Water samples from wells in Pennsylvanian aquifers, representing seven formations, were highly variable with no strong signature of water type (fig. 12E). Water samples from wells in Permian aquifers (fig. $12 F$ ) were either a calcium bicarbonate type or a sodium bicarbonate type.

\section{Nutrients}

All life requires several elements; these "essential" nutrients are foundations of the cells that constitute living organisms. Of the essential nutrients, nitrogen and phosphorus are often limiting nutrients, available at proportionately lower concentrations that limit growth and production. Nutrients are derived from mineral sources as well as organic matter, including plant and animal matter, excreted waste, and atmospheric deposition of combustion by-products. To increase yields, nitrogen and phosphorus, along with potassium, are often added to croplands as fertilizers. Although much of West Virginia receives very little nitrogen or phosphorus from farm or non-farm fertilizers, some areas of West Virginia receive high rates of animal-manure fertilizer application. More than 6,000 kilograms per square kilometer of nitrogen from animal manure was applied to agricultural areas and grasslands in the counties of the Eastern Panhandle in 1997 (Ruddy and others, 2006). Application of farm and non-farm nitrogen fertilizers decreased throughout much of West Virginia from 1987 to 1997, whereas application of nitrogen as animal manure increased in many areas of the State during the same period. Much of West Virginia lies in an area that receives high loads of nitrogen from atmospheric deposition, greater than 400 kilograms per square kilometer (Ruddy and others, 2006). Regardless of the source, nutrients can make their way into groundwater. 


\section{A. Quaternary aquifers}

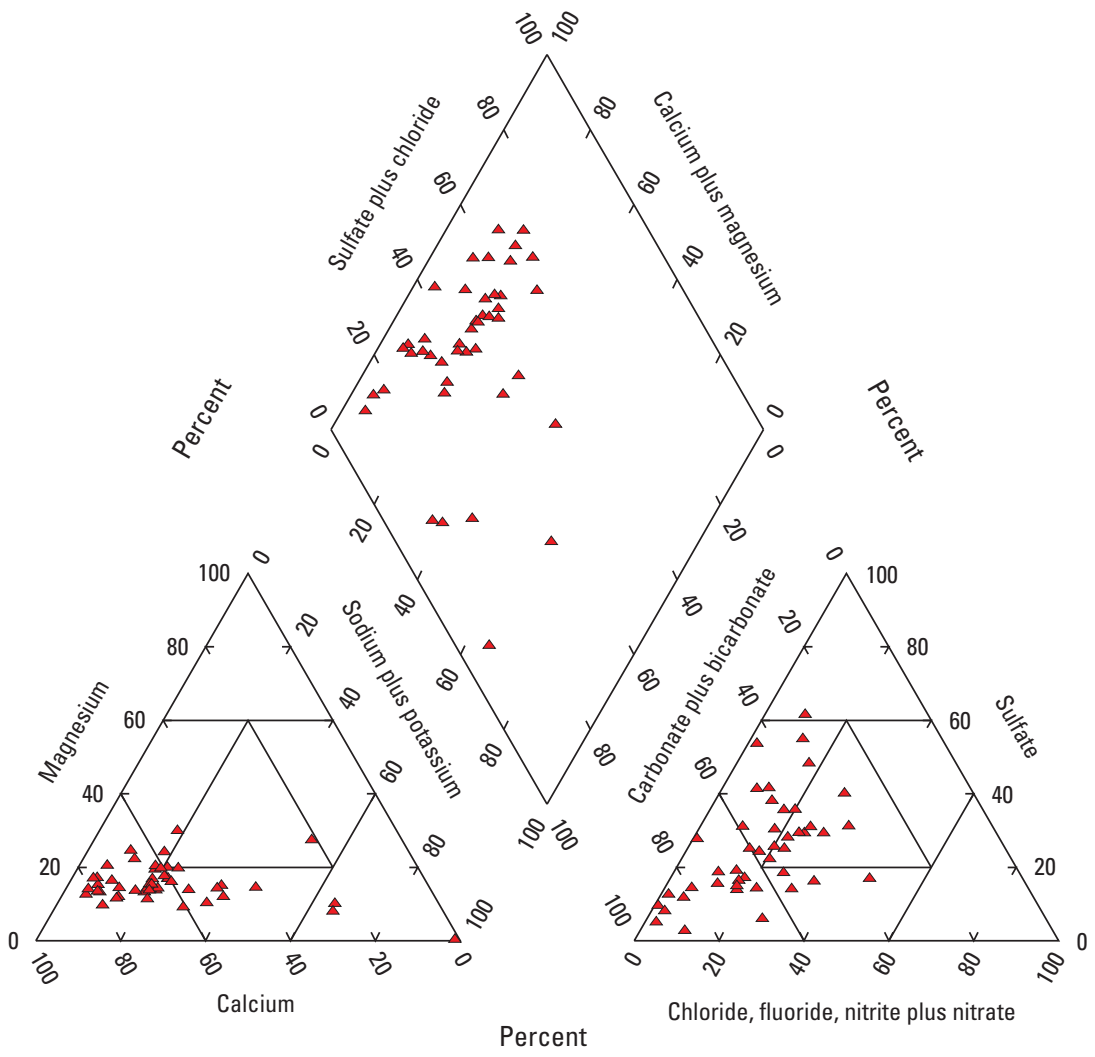

\section{B. Cambrian, Ordovician, and Silurian aquifers}

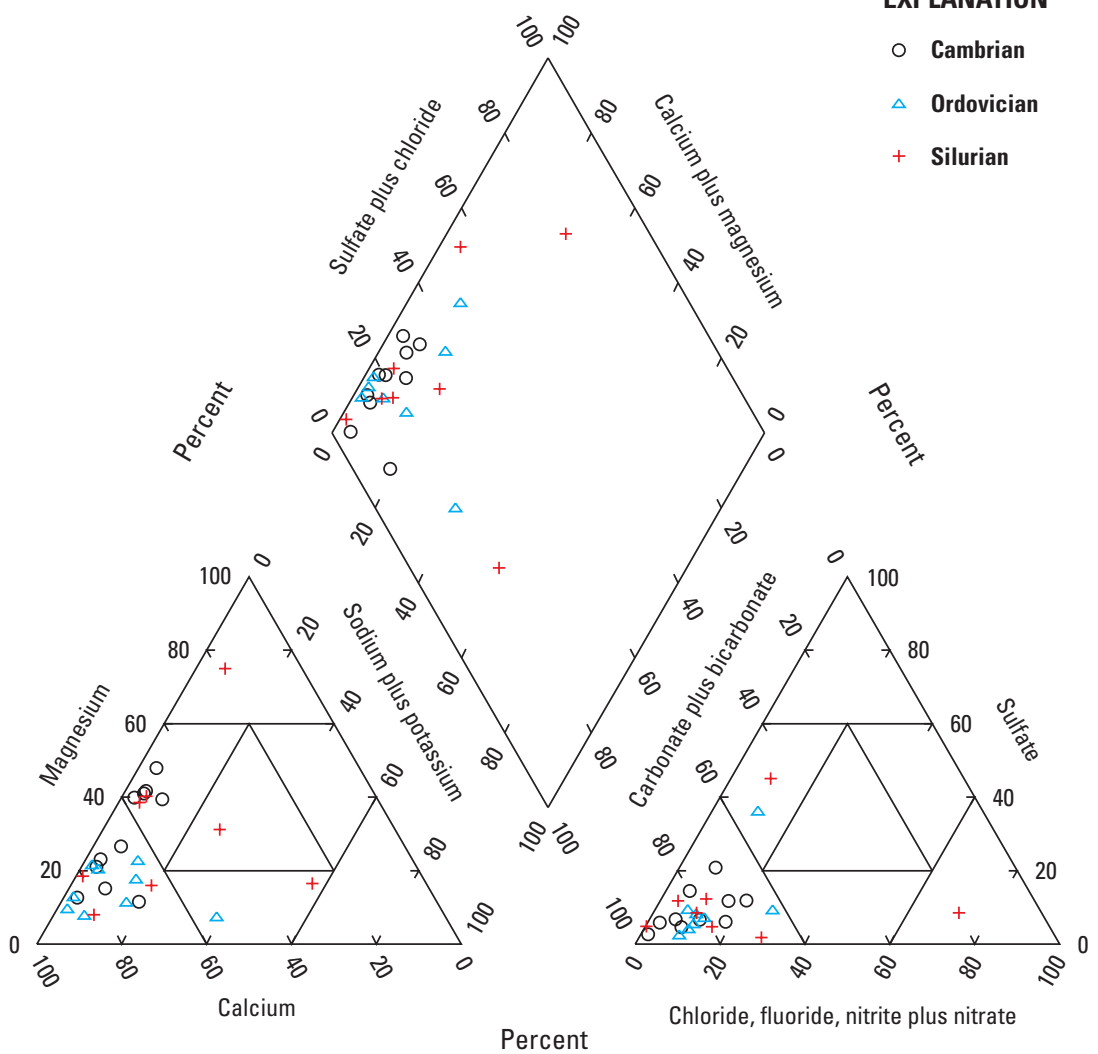

Figure 12. Piper trilinear plots of indicating major ion composition of groundwater samples from the West Virginia ambient monitoring network, grouped by geologic age of the aquifers, 1993-2008: A, Quaternary aquifers; $B$, Cambrian, Ordovician, and Silurian aquifers; $C$, Devonian aquifers; $D$, Mississippian aquifers; $E$, Pennsylvanian aquifers; and $F$, Permian aquifers. 


\section{Devonian aquifers}

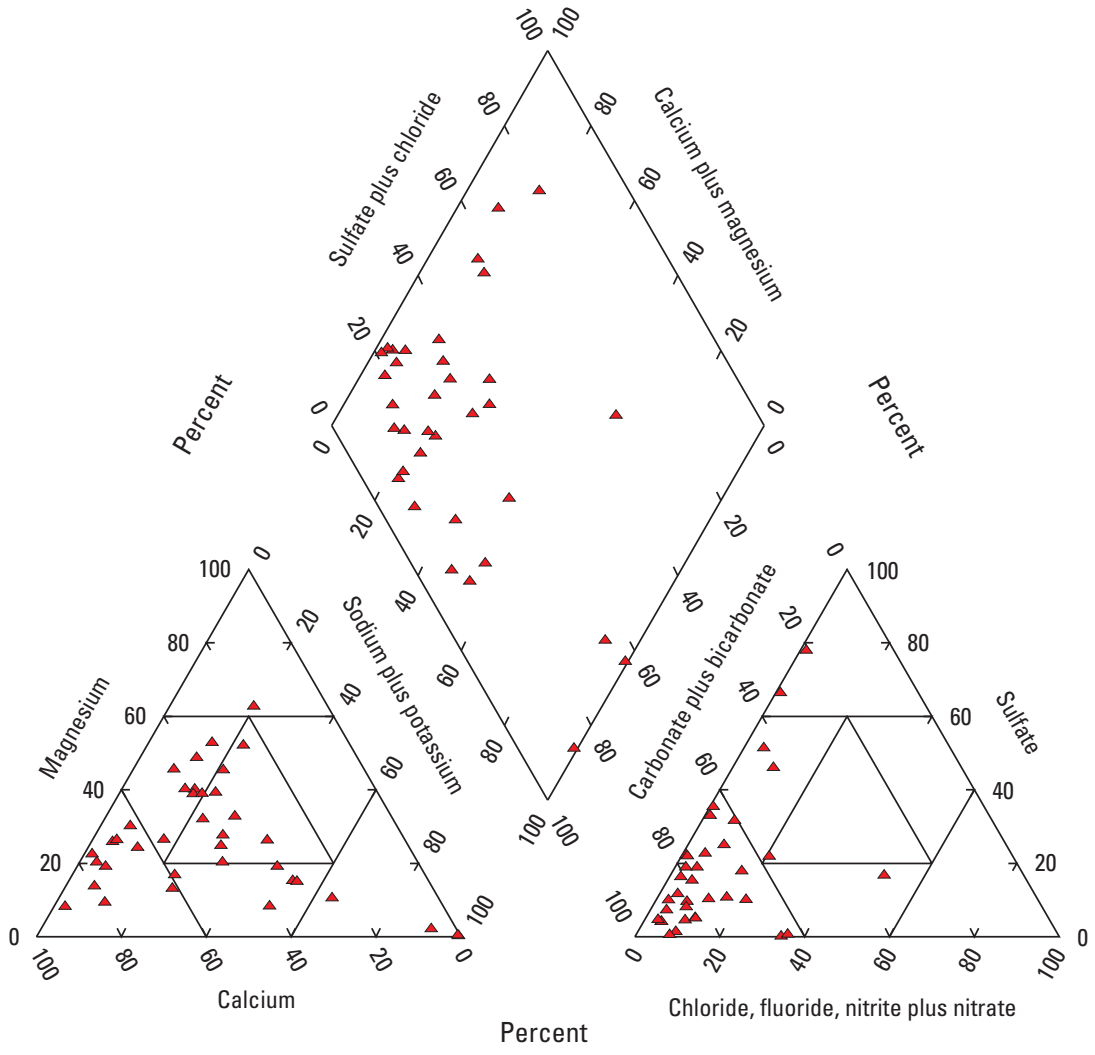

\section{Mississippian aquifers}

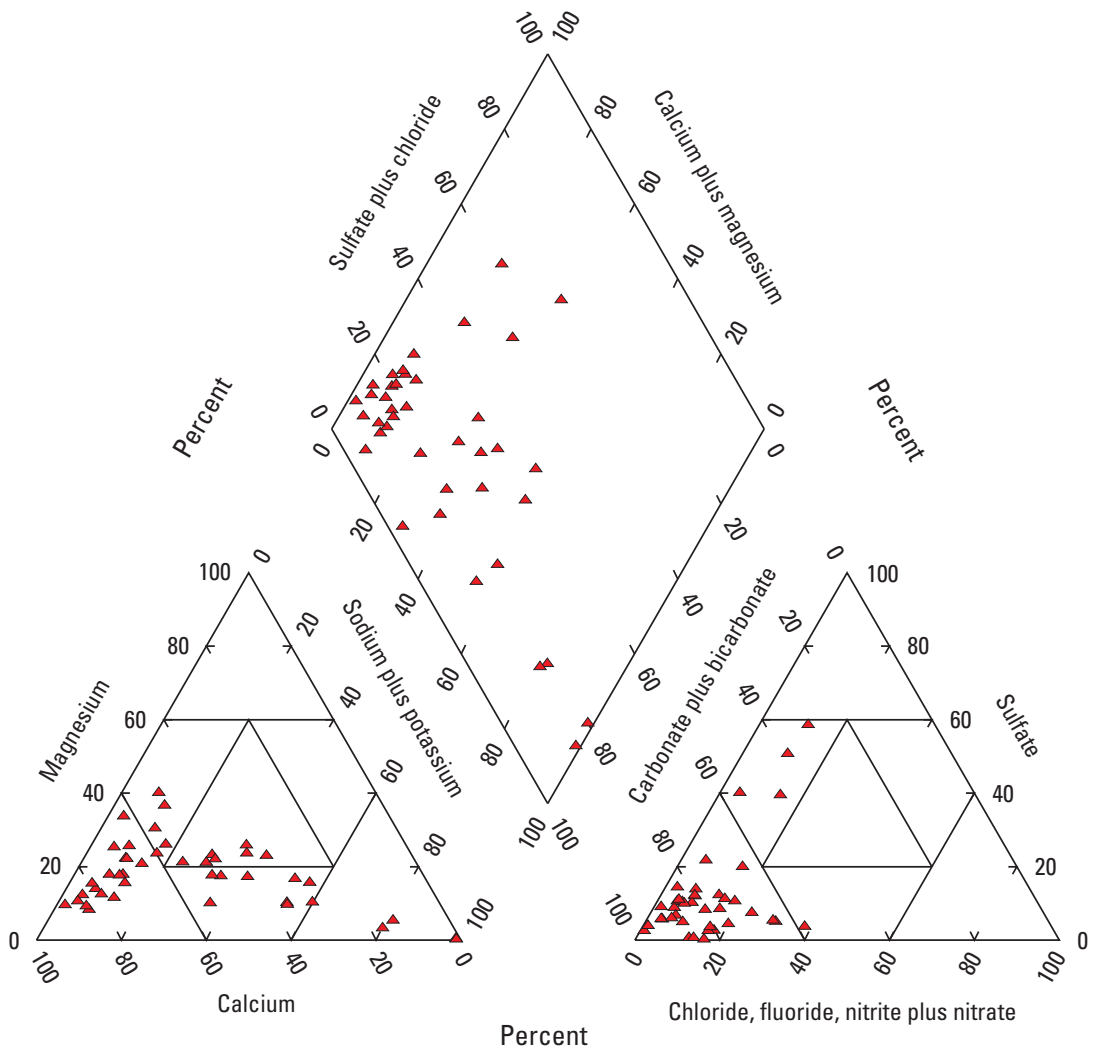

Figure 12. Piper trilinear plots of indicating major ion composition of groundwater samples from the West Virginia ambient monitoring network, grouped by geologic age of the aquifers, 1993-2008: $A$, Quaternary aquifers; $B$, Cambrian, Ordovician, and Silurian aquifers; $C$, Devonian aquifers; $D$, Mississippian aquifers; $E$, Pennsylvanian aquifers; and $F$, Permian aquifers.

-Continued 


\section{E. Pennsylvanian aquifers}

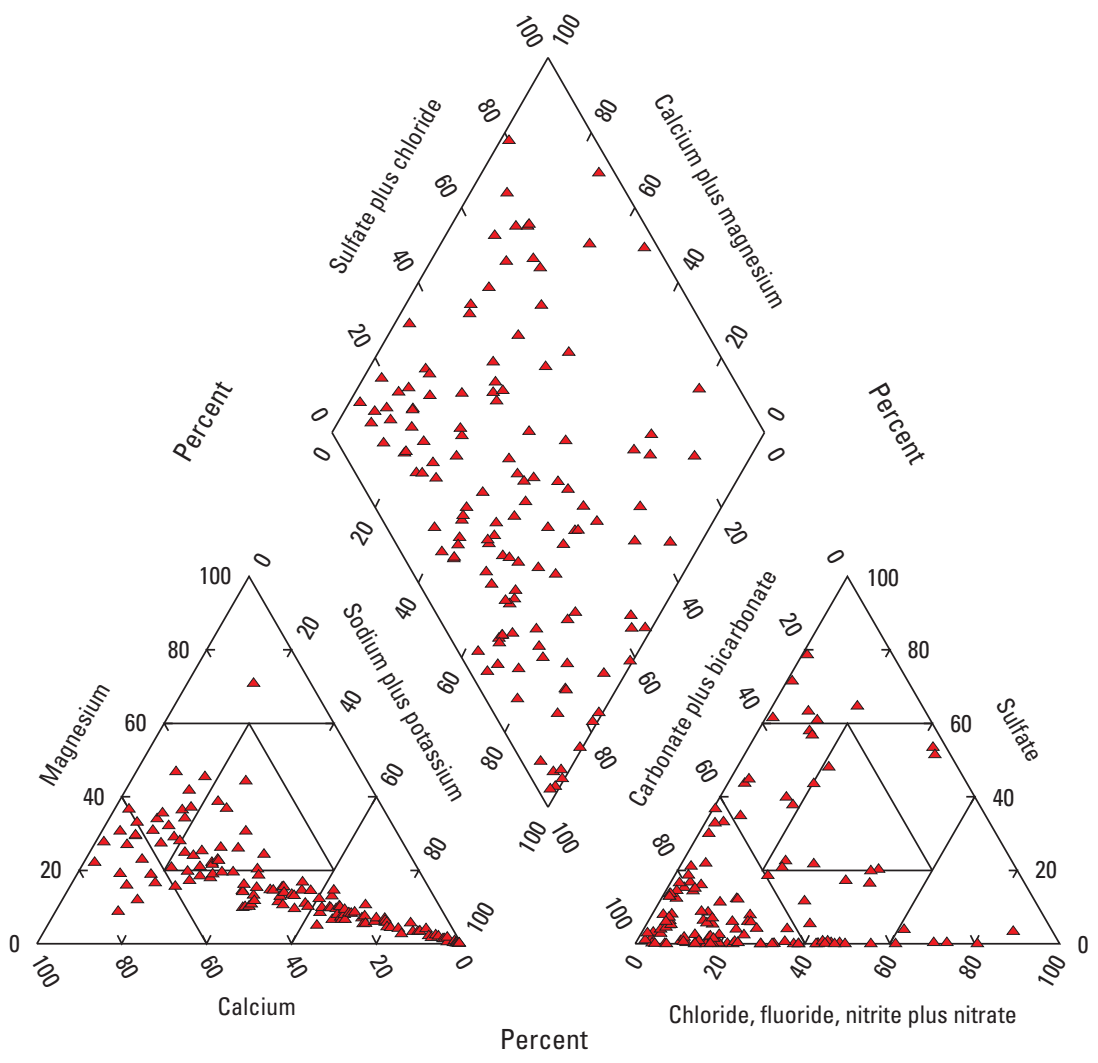

\section{F. Permian aquifers}

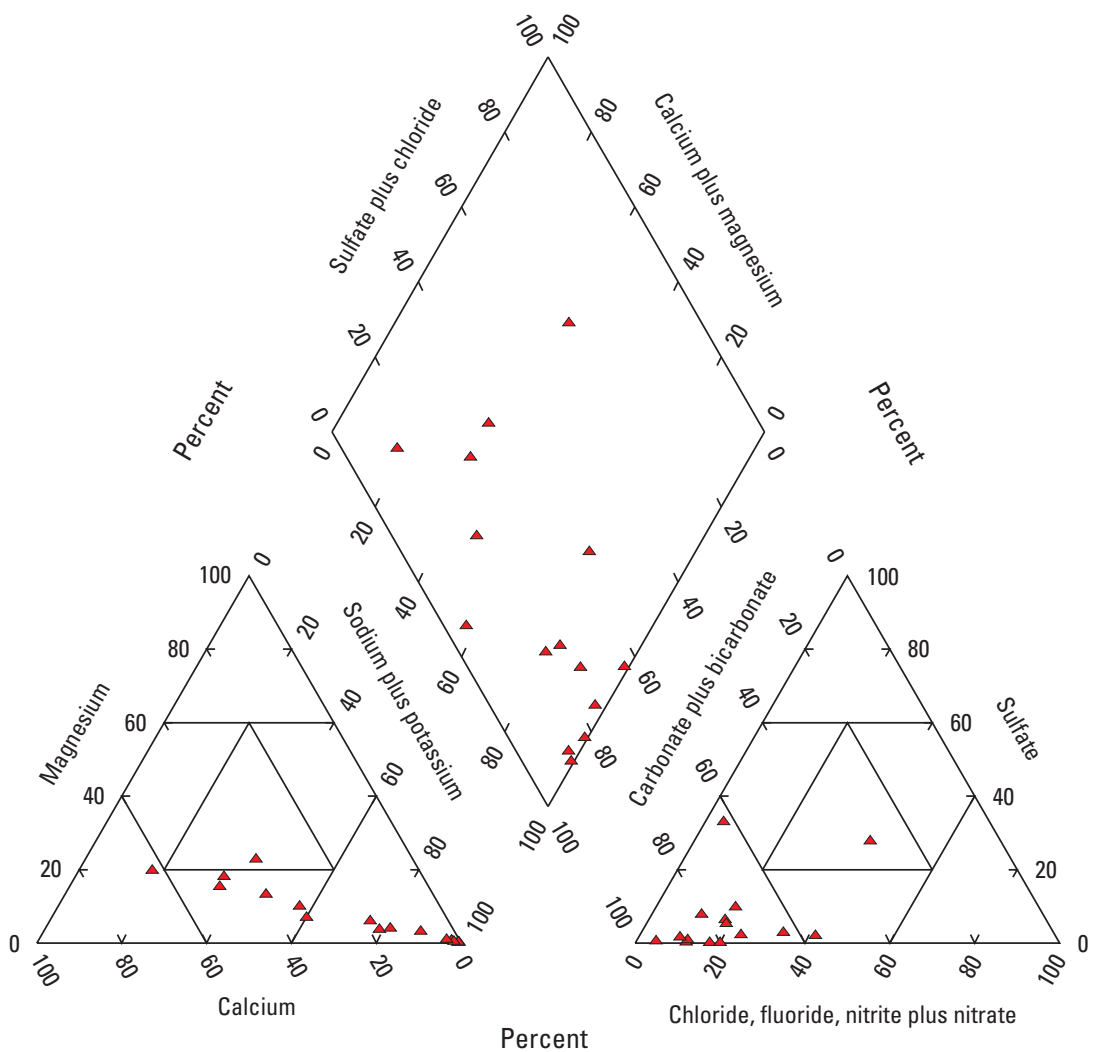

Figure 12. Piper trilinear plots of indicating major ion composition of groundwater samples from the West Virginia ambient monitoring network, grouped by geologic age of the aquifers, 1993-2008: $A$, Quaternary aquifers; $B$, Cambrian, Ordovician, and Silurian aquifers; $C$, Devonian aquifers; $D$, Mississippian aquifers; $E$, Pennsylvanian aquifers; and $F$, Permian aquifers. 


\section{Nitrogen}

Several species of nitrogen are commonly found in groundwater including nitrate, nitrite, ammonia, and organic nitrogen. Nitrogen in groundwater can come from percolation of fertilizers into aquifers; wastewater discharge, including leachate from wastewater-treatment plants and septic tanks; and natural sources. In general, nitrogen species occur at relatively low levels in West Virginia groundwater.

Although many species of nitrogen are commonly found in groundwater, an MCL has been established only for nitrate, at $10 \mathrm{mg} / \mathrm{L}$ as N, and nitrite, at $1 \mathrm{mg} / \mathrm{L}$ as N (U.S. Environmental Protection Agency, 2009b). Concentrations less than 10 and $1 \mathrm{mg} / \mathrm{L}$ as $\mathrm{N}$ for nitrate and nitrite, respectively, protect infants younger than 6 months from potentially lethal methemoglobinemia, also known as "blue baby syndrome." Nitrate was detected in less than 40 percent of the samples and nitrite in less than 11 percent of the samples. For all samples, nitrate plus nitrite concentrations ranged from less than a method reporting level of $0.02 \mathrm{mg} / \mathrm{L}$ to $11 \mathrm{mg} / \mathrm{L}$, and the median value for nitrate plus nitrite was less than the reporting level. Median nitrate plus nitrite concentrations also were less than the reporting levels in samples from wells that tap Devonian, Mississippian, Pennsylvanian, and Permian aquifers (fig. 13). The highest nitrate plus nitrite concentration of $11 \mathrm{mg} / \mathrm{L}$ (nitrite concentration in this sample was less than $0.01 \mathrm{mg} / \mathrm{L}$ ), the only value to exceed the nitrate MCL, was from a well in a Quaternary aquifer; Cambrian aquifers, dominated by limestone rocks, had the highest median value, $3.20 \mathrm{mg} / \mathrm{L}$ as $\mathrm{N}$. The highest nitrate plus nitrite values were consistently from either an alluvium- or limestone-dominated setting. These are settings where West Virginia's agricultural activities are concentrated; aquifers have greater transmissivity (Kozar and Mathes, 2001); and the potential is great for rapid transport of contaminants, such as excess fertilizer, from the surface to groundwater.

Analyses were performed for ammonia and total nitrogen concentrations. Concentrations ranged from less than a method reporting level of $0.01 \mathrm{mg} / \mathrm{L}$ to $2.76 \mathrm{mg} / \mathrm{L}$ as N. Ammonia was found in concentrations greater than the reporting level in 238 samples. Ammonia was the dominant nitrogen species found in sandstone, shale, and mixed shalesandstone dominated areas. Ammonia used in the treatment of coal-mine drainage is a possible source in these areas. Analyses for total nitrogen were performed only on samples collected after 2004. Total nitrogen concentrations ranged from less than $0.06 \mathrm{mg} / \mathrm{L}$ to $7.48 \mathrm{mg} / \mathrm{L}$. A qualitative review of the data indicates that nitrate accounts for most of the total nitrogen in limestone-dominated areas, whereas ammonia accounts for most of the total nitrogen in sandstone- and shale-dominated areas. This may reflect the different sources of nitrogen in these areas.

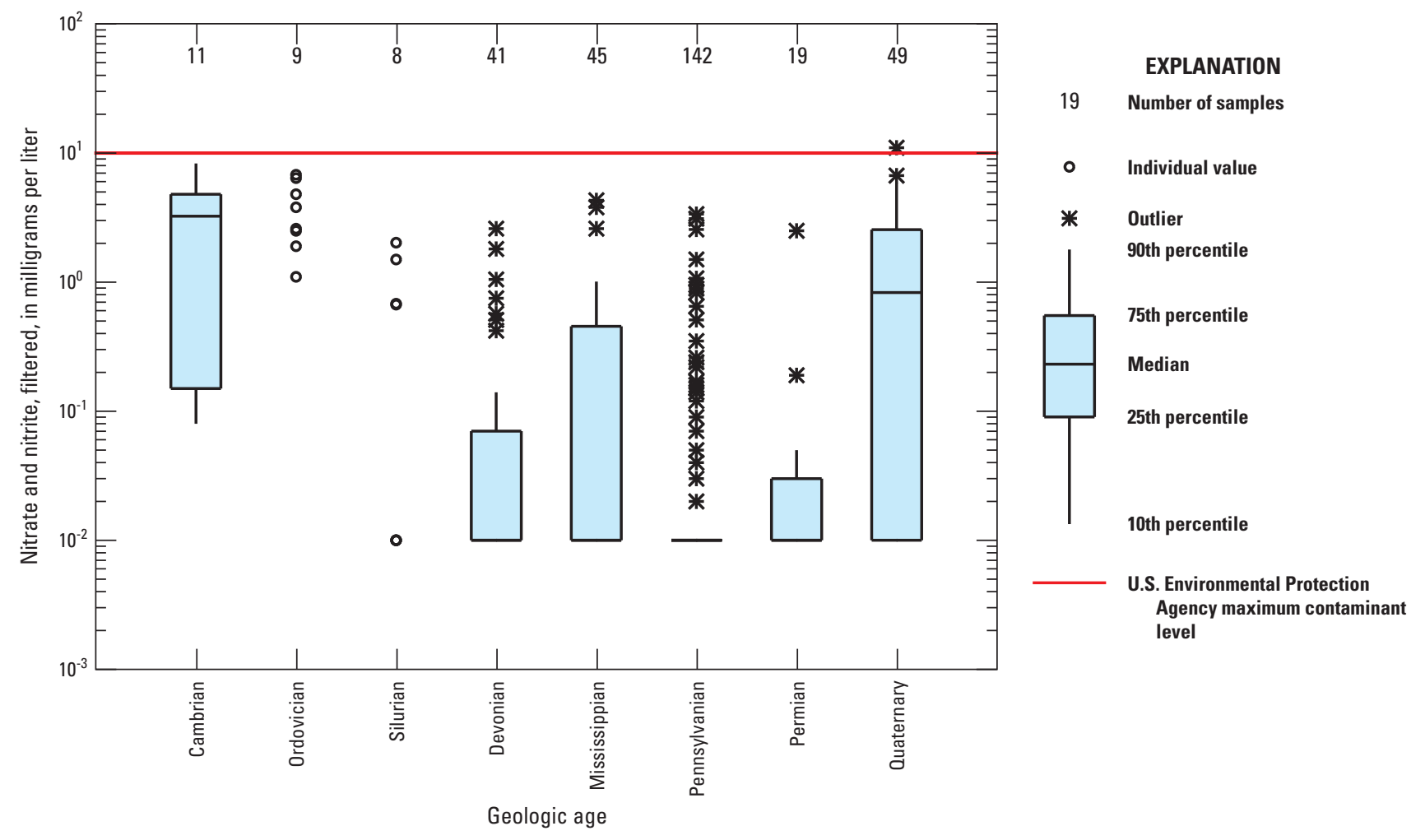

Figure 13. Distribution of nitrate and nitrite concentrations in groundwater samples from the West Virginia ambient monitoring network, grouped by geologic age of the aquifers, 1993-2008. U.S. Environmental Protection Agency (2009b) maximum contaminant level of 10 milligrams per liter for finished drinking water is shown. 


\section{Phosphorus}

Phosphorus, the other major nutrient measured as part of this study, was commonly detected both as total phosphorus, analyses for which were performed on all samples, and orthophosphate, analyses for which were performed only on samples collected from 2005 through 2008. Most values, 90 percent, for total phosphorus and orthophosphate were less than 0.15 and $0.085 \mathrm{mg} / \mathrm{L}$, respectively. No MCLs, SMCLs, or HBSLs have been established for total phosphorus or orthophosphate.

Concentrations of total phosphorus and orthophosphate were highest in areas dominated by mixed shale-sandstone rocks. Total phosphorus concentrations in areas dominated by either sandstone or shale rocks were similar to those in areas of mixed shale-sandstone rocks. However, orthophosphate concentrations were lower in both sandstone- and shaledominated areas than in the mixed shale-sandstone areas. The lowest median values for total phosphorus and orthophosphate were for samples from limestone-dominated areas, $0.01 \mathrm{mg} / \mathrm{L}$ and $0.006 \mathrm{mg} / \mathrm{L}$, respectively.

\section{Fecal-Indicator Bacteria}

Fecal-indicator bacteria occur naturally in the intestines of warm-blooded animals, including humans, and are excreted in feces. Although fecal-indicator bacteria rarely cause illness themselves, their presence in groundwater indicates the possible presence of pathogens associated with fecal contamination from sewage, agricultural activities, or other sources. The preferred fecal-indicator bacteria analyses have changed over time, as simpler more accurate tests have been developed for indicator bacteria that have strong correlations with the occurrence of illness. Over the course of this study, several indicator bacteria and methods of analysis have been used. Fecal coliform bacteria, identified and enumerated using the fecal coliform membrane filtration method (M-FC), have been analyzed for throughout the duration of this study (American Public Health Association and others, 2005b). Various tests for Escherichia coli (E. coli), a species of gut bacteria with a strong correlation to illness following consumption or contact with contaminated water, have been used during this study. Beginning in 2006, the Colilert $^{\circ}$ defined substrate method was used to determine concentrations of $E$. coli in water samples (American Public Health Association and others, 2005a).

The USEPA MCL (U.S. Environmental Protection Agency, 2009b) stipulates that a positive result for either fecal coliform or $E$. coli in a routine sample triggers a repeat sample. A violation of the MCL occurs if the repeat sample is also positive. Although repeat samples were not collected from any site in this study, a positive result from the single sample collected was a presumptive indication of contamination by fecal matter.

Fecal matter and fecal indicator bacteria can be introduced to wells by percolation of nearby surface sources, surface runoff flowing into inadequately cased or grouted wells, or failure of subsurface sewage lines and septic tanks. Fecal coliform bacteria were detected in 32 of 320 wells sampled from 1993 to 2008; E. coli were detected in 8 of 90 samples analyzed using the Colilert $^{\circ}$ method (American Public Health Association and others, 2005) from 2006 to 2008. No strong spatial patterns were observed in the occurrence of fecal coliform bacteria or E. coli (fig. 14). However, samples from springs, which are particularly susceptible to contamination from surface activities, frequently had quantifiable concentrations of fecal coliform bacteria. Fecal coliform bacteria were detected in 67 percent of spring samples (6 of 9), whereas fecal coliform bacteria were detected in approximately 8 percent of well samples.

\section{Trace Elements}

Trace elements typically occur in natural waters in concentrations less than $1.0 \mathrm{mg} / \mathrm{L}$ (Hem, 1985). Although these elements occur at low concentrations, they may have adverse health effects or unpleasant aesthetic effects, such as a displeasing taste or odor of drinking water, staining of teeth or skin, or staining of plumbing fixtures or laundry. Of the 15 trace elements that were analyzed for in samples (table 5), the USEPA has developed primary MCLs for 10 trace elements and SMCLs for another 4 trace elements (U.S. Environmental Protection Agency, 2009b). Additionally, HBSLs have been developed for manganese, nickel, and zinc (Toccalino and others, 2008).

In samples collected as part of this study, antimony, beryllium, cadmium, chromium, mercury, and selenium were rarely detected and when detected did not exceed any drinking-water criteria. Thallium was not detected in any sample. Arsenic, aluminum, barium, iron, manganese, lead, nickel, and zinc were routinely detected in samples, and all but nickel exceeded a drinking-water criterion.

\section{Arsenic}

Arsenic, a metalloid element, when consumed in drinking water can cause bladder, lung, and skin cancers and can also be responsible for neurological and cardiovascular effects (National Research Council, 2001; World Health Organization, 2006). In 2006, the MCL for total arsenic was lowered from $50 \mu \mathrm{g} / \mathrm{L}$ to $10 \mu \mathrm{g} / \mathrm{L}$ (Federal Register, 2001). Arsenic concentrations ranged from less than a method reporting level of $0.2 \mu \mathrm{g} / \mathrm{L}$ in many wells to $138 \mu \mathrm{g} / \mathrm{L}$ in a well completed in a Mississippian aquifer in Summers County, West Virginia; arsenic was not present in a detectable concentration in more than 60 percent of the samples.

Arsenic concentrations differed by geologic age of aquifers with median concentrations less than the method detection level in Mississippian, Pennsylvanian, and Quaternary aquifers. The highest median concentration for any rock type was $1.16 \mu \mathrm{g} / \mathrm{L}$, which was present in a sample from a well in a Permian aquifer. 


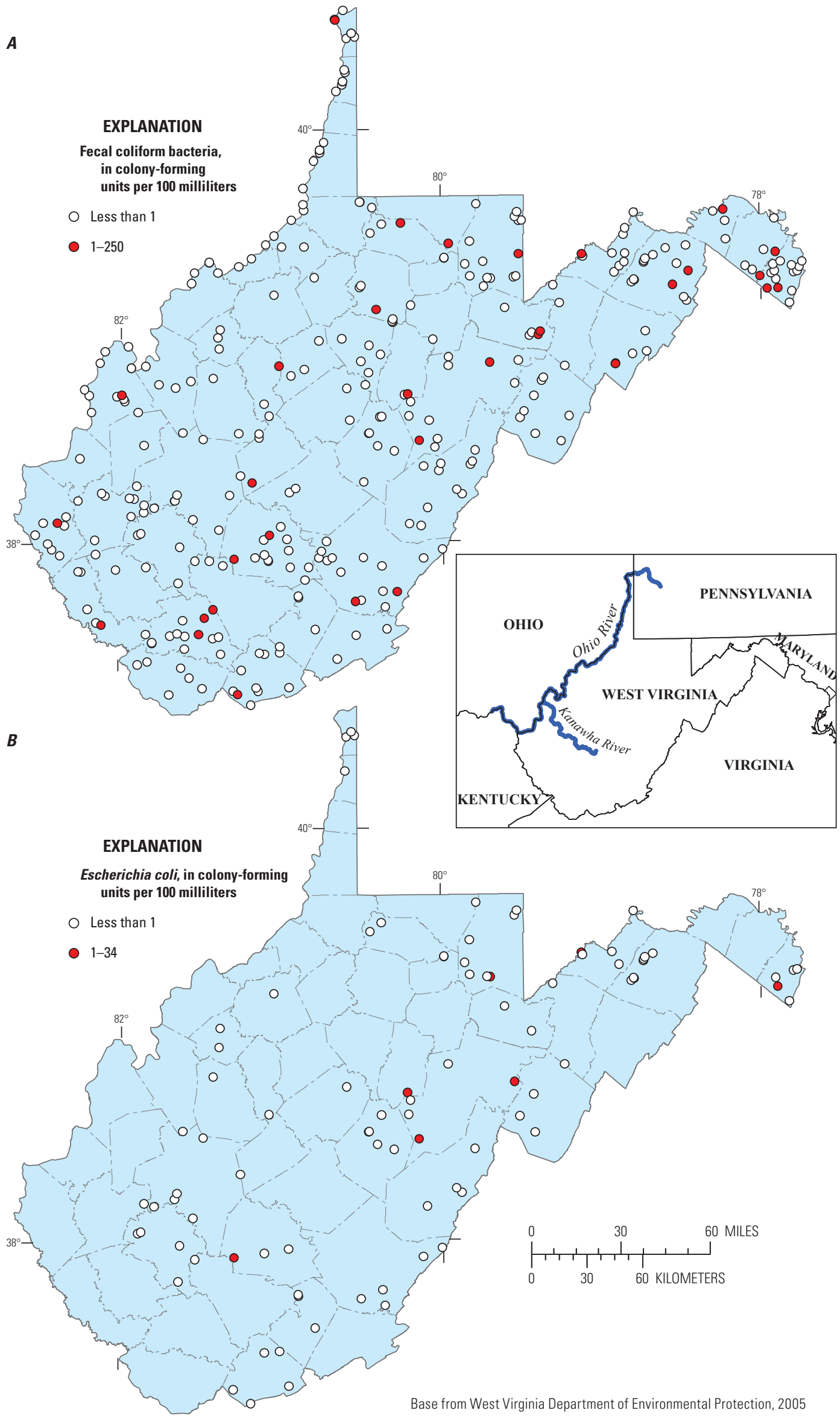

Figure 14. Distribution of groundwater samples from the West Virginia ambient monitoring network with at least one colony-forming unit of fecal indicator bacteria per 100 milliliters of sample, 1993-2008: A, Fecal coliform and $B$, Escherichia coli. 


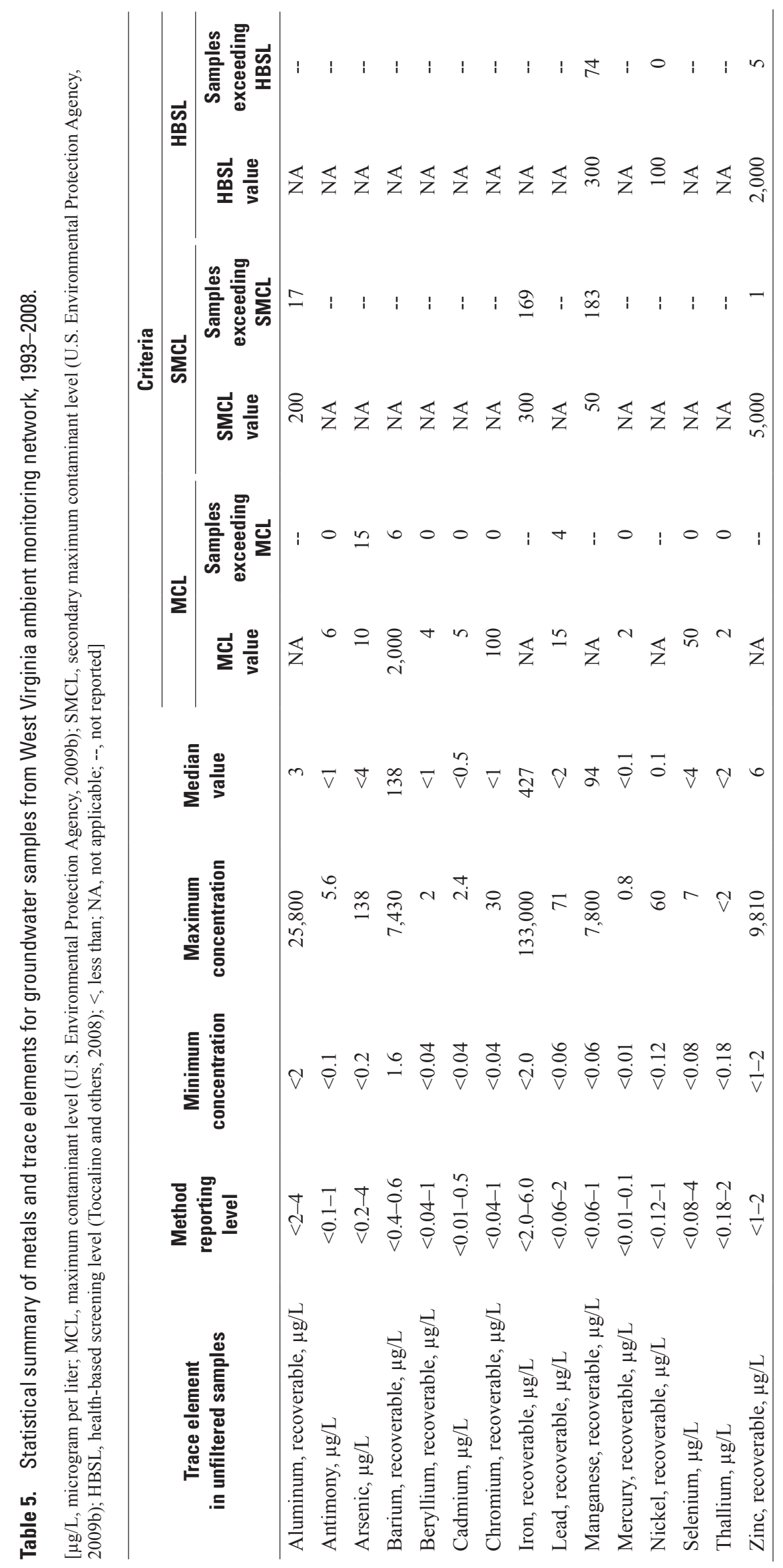


Although most arsenic concentrations were less than the reporting level, samples from 15 wells exceeded the $10 \mu \mathrm{g} / \mathrm{L}$ MCL (fig. 15). Arsenic concentrations exceeding the MCL were found in six samples from Pennsylvanian aquifers, four from Devonian aquifers, two from Mississippian aquifers, and one each from Silurian, Permian, and Quaternary aquifers.

\section{Aluminum}

Aluminum, the third most common crustal element, typically occurs in concentrations less than $0.1 \mathrm{mg} / \mathrm{L}$ in natural waters (Hem, 1985). Currently there is no health-based criterion for aluminum, although there is some concern about aluminum neurotoxicity (World Health Organization, 2006). A SMCL of 50 to $200 \mu \mathrm{g} / \mathrm{L}$ (U.S. Environmental Protection Agency, 2009b) has been established for aluminum for aesthetic effects, primarily discoloration of water. The lower limit is a goal concentration for finished water, but the range allows regulators to set system-by-system limits. Aluminum concentrations in this study ranged from less than a method reporting level of $2 \mu \mathrm{g} / \mathrm{L}$ to $25,800 \mu \mathrm{g} / \mathrm{L}$ with a median value of $3 \mu \mathrm{g} / \mathrm{L}$. Most of the values, 80 percent, ranged from the method reporting level to $88 \mu \mathrm{g} / \mathrm{L}$.

Aluminum concentrations differed significantly with geologic age of the aquifer (Kruskal-Wallis rank sum test $\mathrm{p}$-value $=0.0008$ ). Median aluminum values ranged from less than the method reporting level of $2 \mu \mathrm{g} / \mathrm{L}$ for samples from wells in areas of Cambrian and Quaternary aquifers to $7 \mu \mathrm{g} / \mathrm{L}$ for samples from wells in Permian aquifers (fig. 16).

Concentrations of aluminum exceeded the $50 \mu \mathrm{g} / \mathrm{L}$ SMCL goal in 12 percent of samples and the upper SMCL limit $200 \mu \mathrm{g} / \mathrm{L}$ in 5 percent of samples. Most of the samples with aluminum concentrations exceeding the SMCL were from Pennsylvanian aquifers, accounting for 24 of 35 exceedances of the lower limit and 12 of the 17 exceedances of the upper limit. Samples exceeding the SMCL were evenly distributed throughout the eastern part of West Virginia (fig. 17).

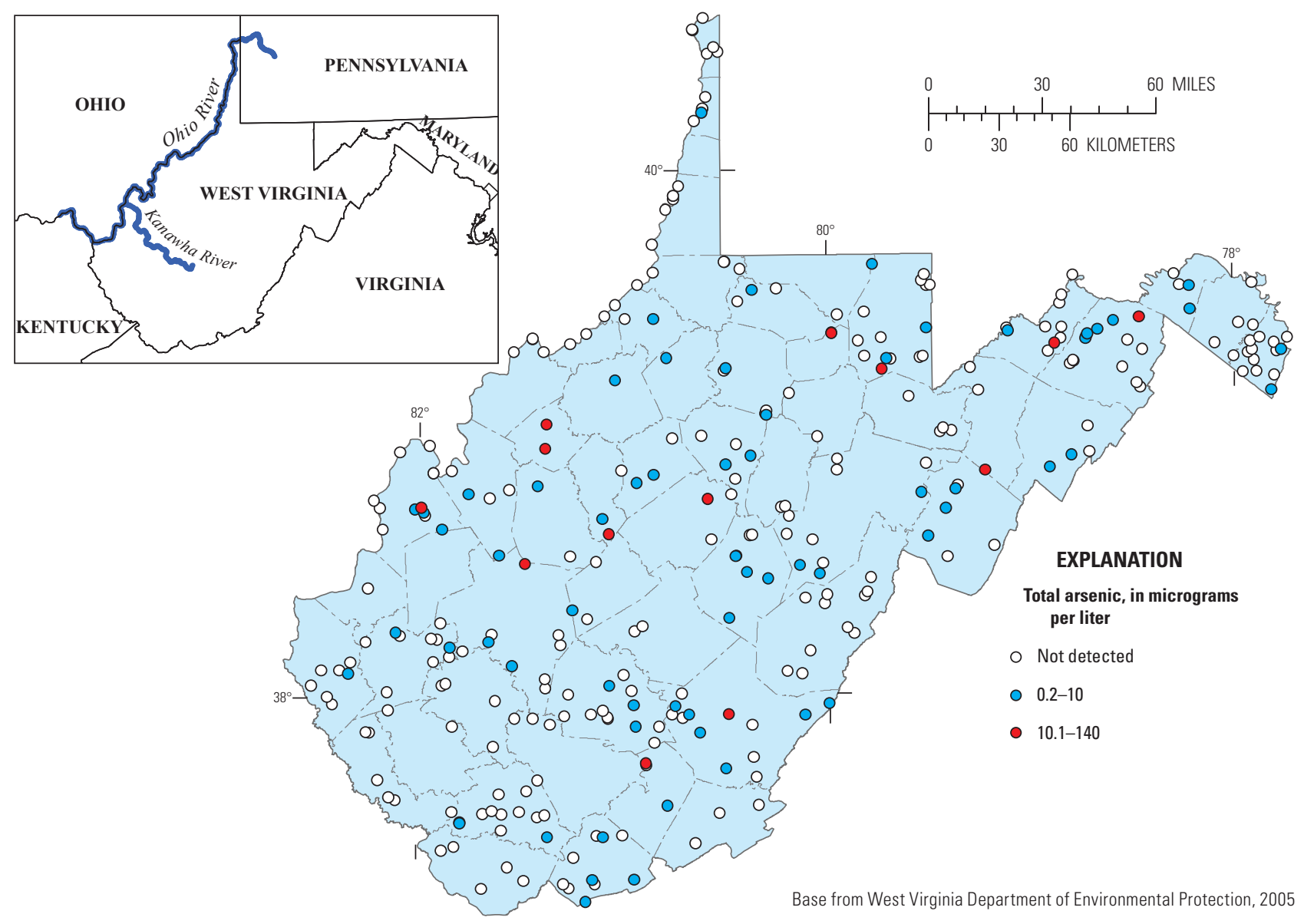

Figure 15. Distribution of groundwater samples from the West Virginia ambient monitoring network analyzed for total arsenic, 1993-2008. Samples exceeding the U.S. Environmental Protection Agency (2009b) maximum contaminant level of 10 micrograms per liter for finished drinking water are shown in red. 


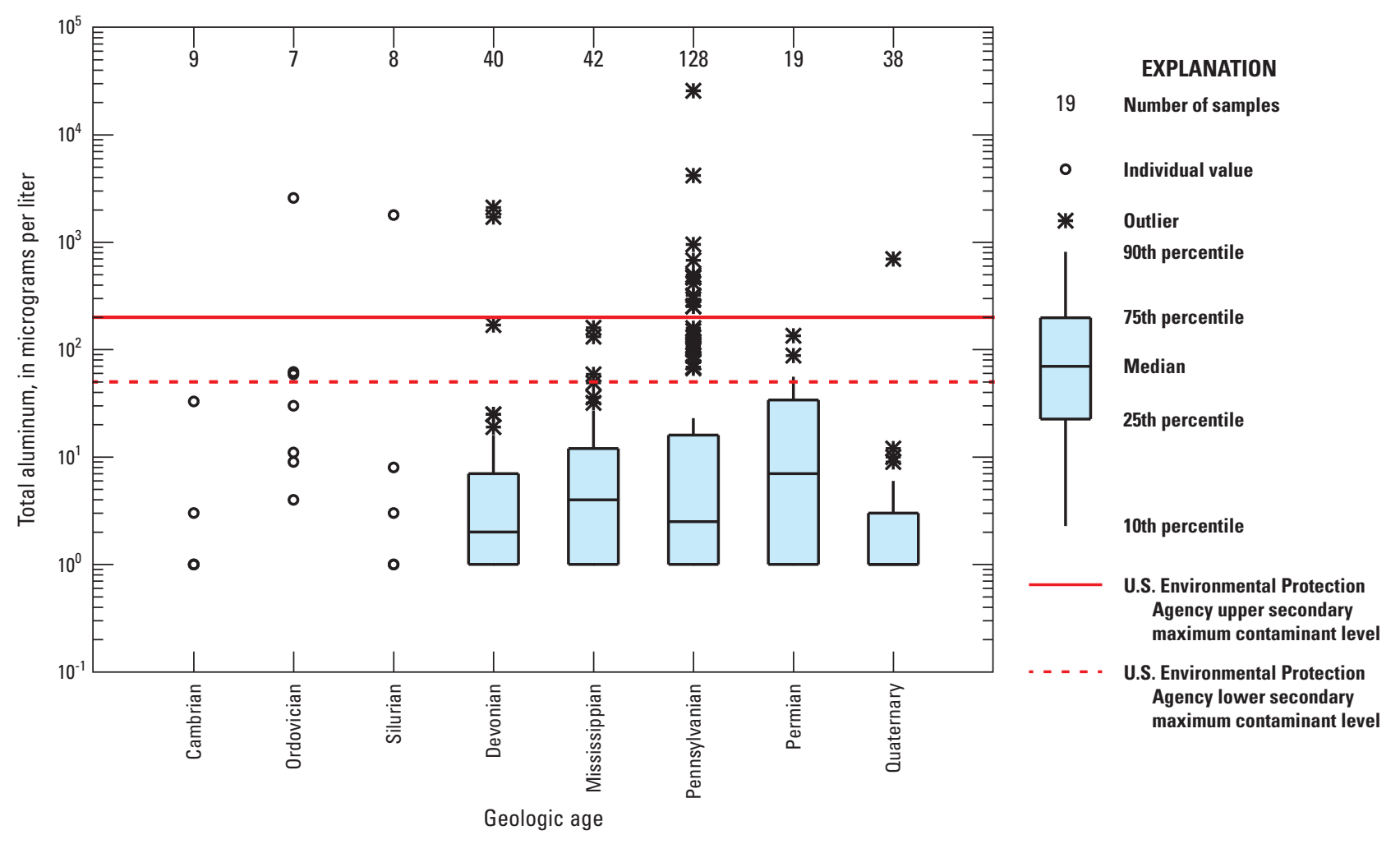

Figure 16. Distribution of aluminum concentrations in groundwater samples from the West Virginia ambient monitoring network, grouped by geologic age of the aquifers, 1993-2008. U.S. Environmental Protection Agency (2009b) secondary maximum contaminant levels of 50 and 200 micrograms per liter for finished drinking water are shown. 


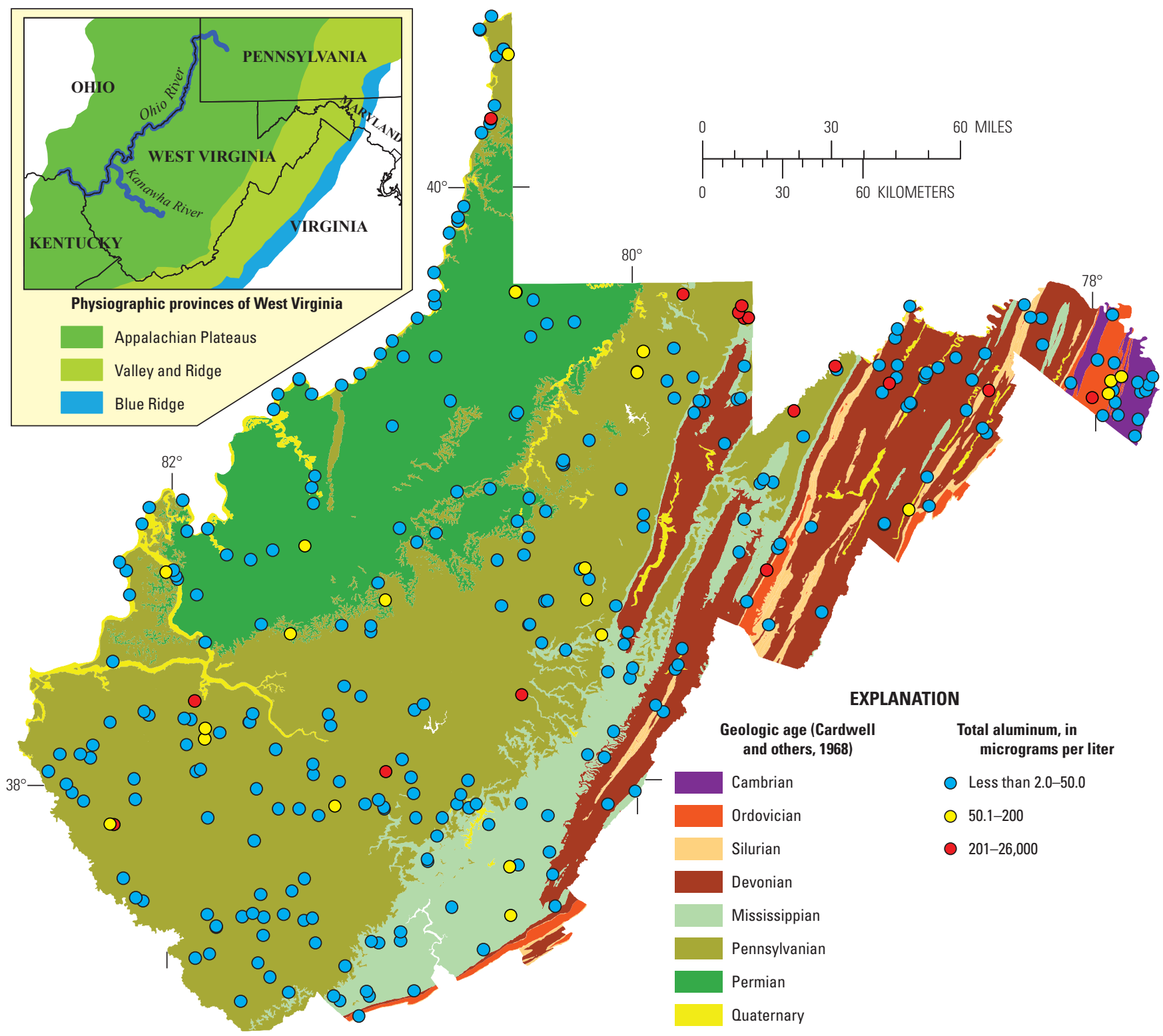

Figure 17. Distribution of groundwater samples from the West Virginia ambient monitoring network analyzed for total aluminum, 1993-2008. Samples exceeding the U.S. Environmental Protection Agency (2009b) secondary maximum contaminant level (SMCL) of 50 micrograms per liter $(\mu \mathrm{g} / \mathrm{L})$ for finished drinking water are shown in yellow; those exceeding the U.S. Environmental Protection Agency (2009b) SMCL of $200 \mu \mathrm{g} / \mathrm{L}$ for finished drinking water are shown in red. 
Iron

Iron is the second most abundant metal in the earth's crust but usually occurs in natural waters as a trace element (Hem, 1985). A major source of iron in West Virginia's waters is the oxidation of pyrite, a common mineral in Appalachian coal-bearing lithologies (Rose and Cravotta, 1998). The USEPA has established a SMCL for iron of $300 \mu \mathrm{g} / \mathrm{L}$ (U.S. Environmental Protection Agency, 2009b) for aesthetic reasons, primarily the staining of laundry and plumbing fixtures. In this study, iron concentrations ranged from less than the method reporting level of $2.0 \mu \mathrm{g} / \mathrm{L}$ to $133,000 \mu \mathrm{g} / \mathrm{L}$ with a median value of $427 \mu \mathrm{g} / \mathrm{L}$ (table 5).

Iron concentrations differed significantly with the geologic age of aquifers (Kruskal-Wallis rank sum test $\mathrm{p}$-value $<0.001$ ) with median values ranging from $14 \mu \mathrm{g} / \mathrm{L}$ in samples from Cambrian aquifers to $922 \mu \mathrm{g} / \mathrm{L}$ in samples from Pennsylvanian aquifers (fig. 18). Most of the samples, 57 percent, exceeded the $300 \mu \mathrm{g} / \mathrm{L} \mathrm{SMCL}$, with most exceedances in Pennsylvanian aquifers (fig. 19). The proportion of samples exceeding the SMCL stands in marked contrast to the 19.1 percent of wells nationally (DeSimone, 2008). The median iron concentrations in samples from Devonian and Pennsylvanian aquifers were greater than the SMCL (fig. 18).

\section{Manganese}

Manganese, although a relatively abundant element, occurs at approximately one-fiftieth of the crustal abundance of iron (Hem, 1985). Manganese commonly occurs at high

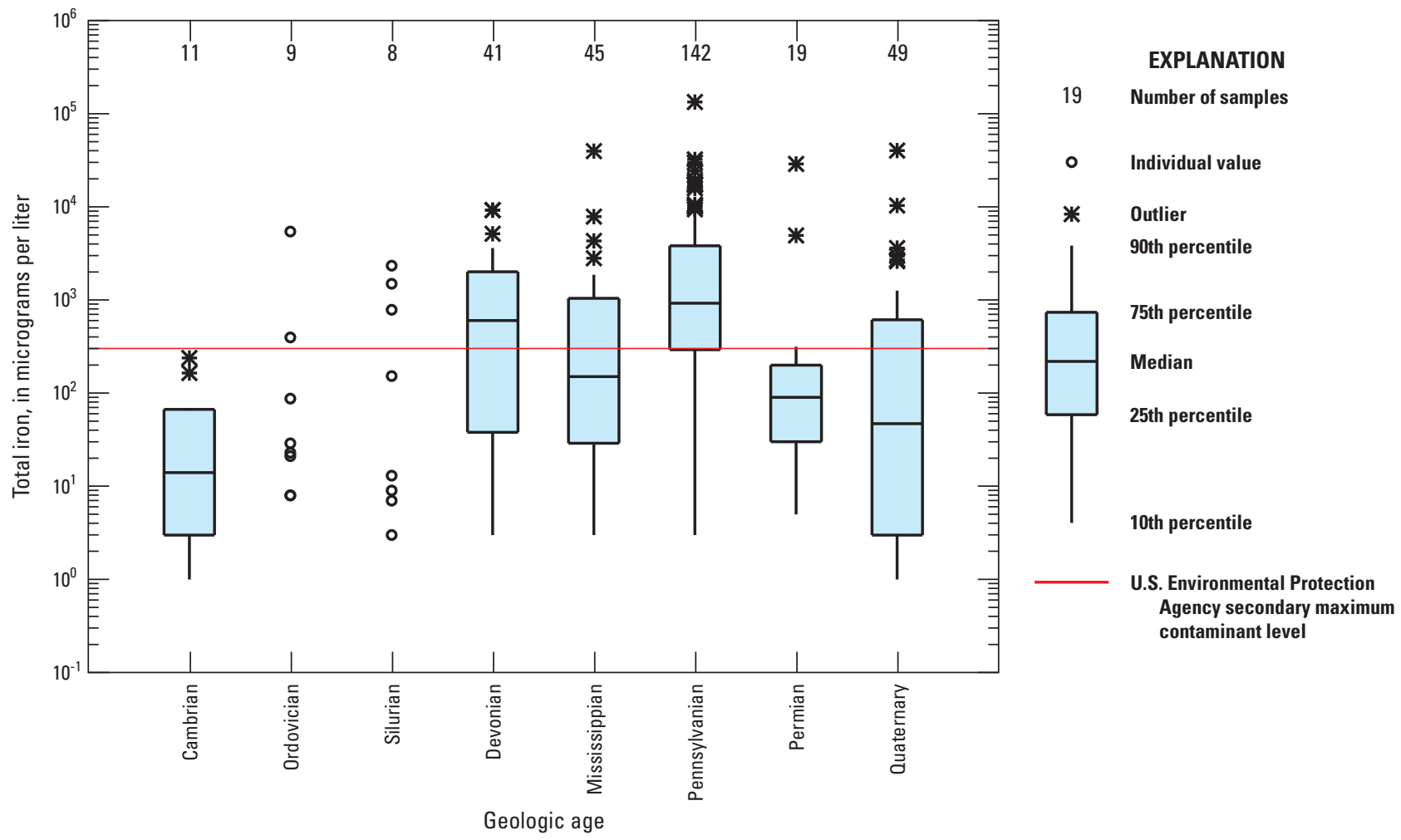

Figure 18. Distribution of iron concentrations in groundwater samples from the West Virginia ambient monitoring network, grouped by geologic age of the aquifers, 1993-2008. U.S. Environmental Protection Agency (2009b) secondary maximum contaminant level of 300 micrograms per liter for finished drinking water is shown. 


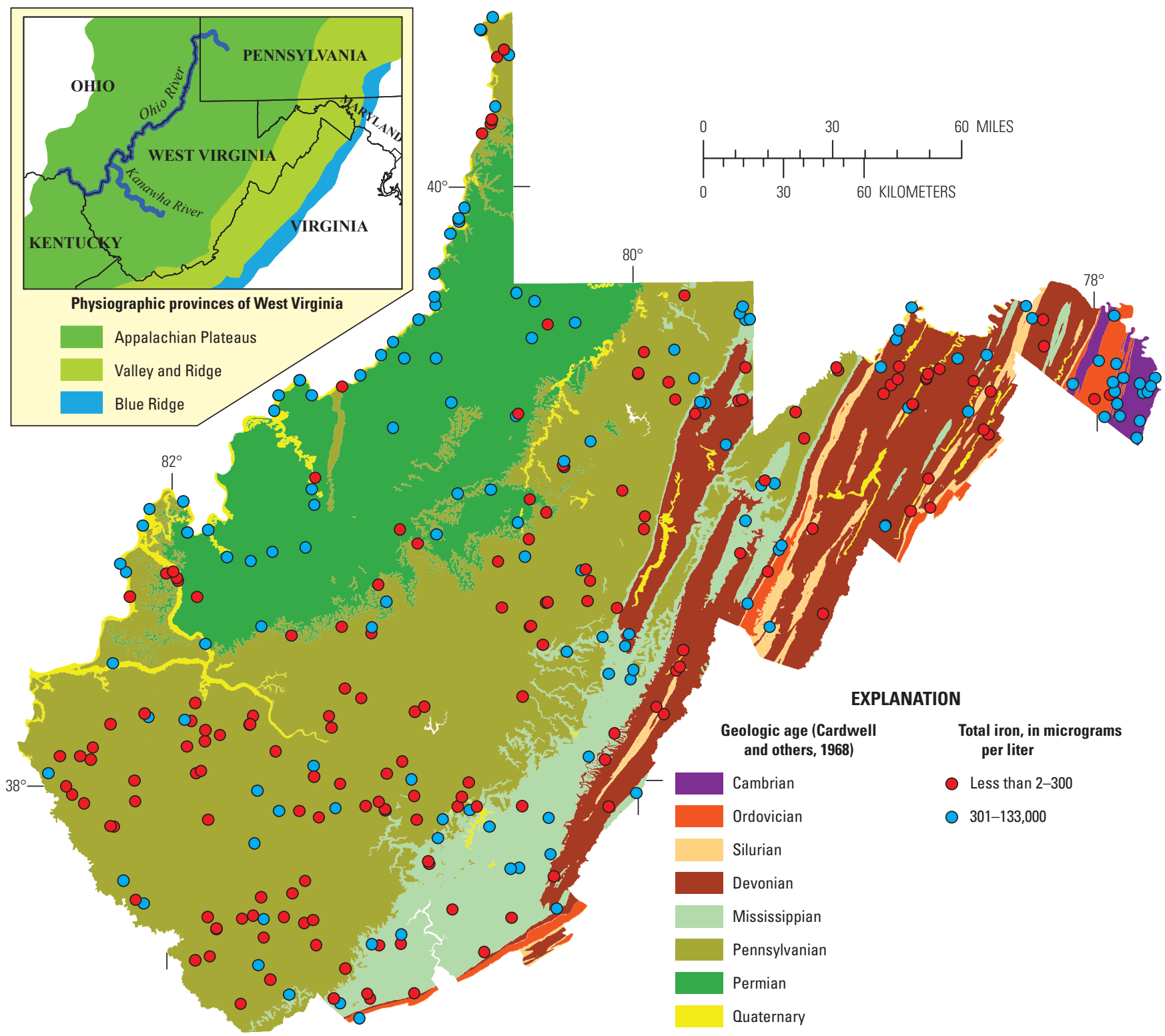

Figure 19. Distribution of groundwater samples from the West Virginia ambient monitoring network analyzed for total iron, 1993-2008. Samples exceeding the U.S. Environmental Protection Agency (2009b) secondary maximum contaminant level of 300 micrograms per liter for finished drinking water are shown in red. 
concentrations with high iron concentrations because both elements are derived from clay minerals in sedimentary rocks (Larsen and Mann, 2005). The USEPA has established a manganese SMCL for aesthetic reasons, primarily the staining of laundry and plumbing fixtures, of $50 \mu \mathrm{g} / \mathrm{L}$ (U.S. Environmental Protection Agency, 2009b). In addition to the SMCL, there is a HBSL of $300 \mu \mathrm{g} / \mathrm{L}$ (Toccalino and others, 2008) based on studies indicating increased risk of central nervous system effects (U.S. Environmental Protection Agency, 2009a). Manganese concentrations in this study ranged from less than the method reporting level of $0.06 \mu \mathrm{g} / \mathrm{L}$ to $7,800 \mu \mathrm{g} / \mathrm{L}$ with a median value of $94 \mu \mathrm{g} / \mathrm{L}$ (table 5 ). Concentrations of most of the samples, 80 percent, were between $1 \mu \mathrm{g} / \mathrm{L}$ and $631 \mu \mathrm{g} / \mathrm{L}$; 62 percent of the samples exceeded the SMCL, and 25 percent exceeded the HBSL.

The lowest median manganese concentration by rock type was $1.0 \mu \mathrm{g} / \mathrm{L}$ for samples from wells in Cambrian aquifers (fig. 20). The highest median concentration, $160 \mu \mathrm{g} / \mathrm{L}$, was from wells in Quaternary aquifers. Manganese concentrations differed significantly by geologic age of the aquifer (Kruskal-Wallis rank sum test $\mathrm{p}$-value $<0.001$ ).

Manganese concentrations in most samples, more than 62 percent, exceeded the $50 \mu \mathrm{g} / \mathrm{L}$ SMCL. More than 25 percent exceeded the HBSL of $300 \mu \mathrm{g} / \mathrm{L}$ (fig. 21). The proportion of samples exceeding either the MCL or the HBSL in this study is much higher than the proportions that DeSimone (2008) found in a nationwide analysis of groundwater from domestic wells in which only 21.3 percent exceeded the SMCL and 5.22 percent exceeded the HBSL. Although the manganese values exceeding the SMCL appear to be distributed somewhat evenly across the study area, SMCL exceedances were more prevalent in water samples from Pennsylvanian aquifers (fig. 21). Additionally, manganese concentrations exceeding the HBSL were more frequent in southern West Virginia where lower Pennsylvanian aquifers dominate. These findings concur with earlier studies that noted higher manganese contaminations in groundwater from Pennsylvanian rocks (Mathes and others, 1998; Rose and Cravotta, 1998).

\section{Lead}

Lead has been widely used in plumbing, in paints, and as a fuel additive, all uses that have contributed to its widespread occurrence in the environment (Hem, 1985). Lead toxicity is well established; neurotoxic effects, developmental delays in children, and other health effects have led the USEPA to establish a public health goal of zero concentration (U.S. Environmental Protection Agency, 2009b). Most of the samples,

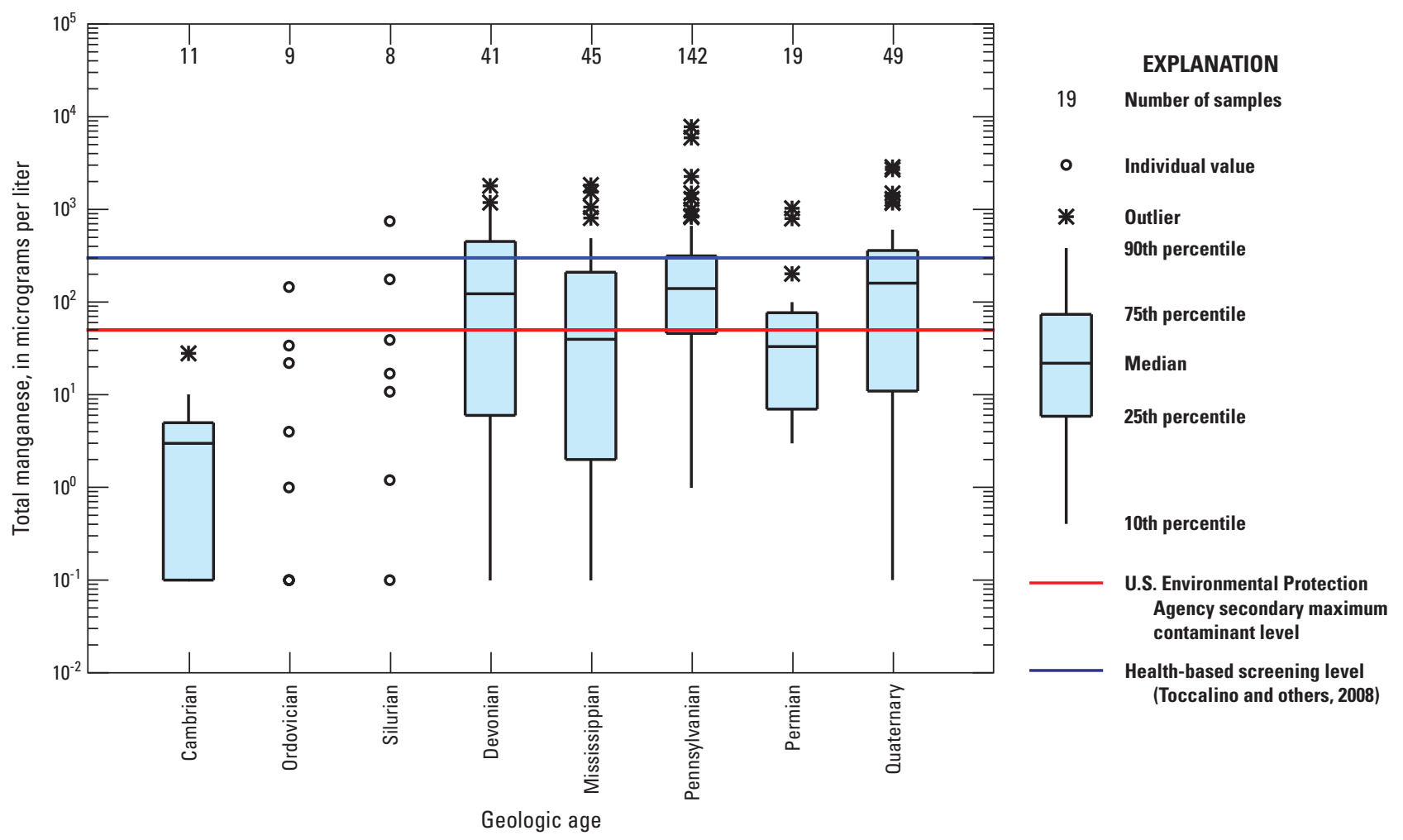

Figure 20. Distribution of manganese concentrations in groundwater samples from the West Virginia ambient monitoring network, grouped by geologic age, 1993-2008. The red line denotes the U.S. Environmental Protection Agency (2009b) secondary maximum contaminant level for finished drinking water of 50 micrograms per liter $(\mu \mathrm{g} / \mathrm{L})$; the blue line denotes a health-based screening level (Toccalino and others, 2008) of $300 \mu \mathrm{g} / \mathrm{L}$. 


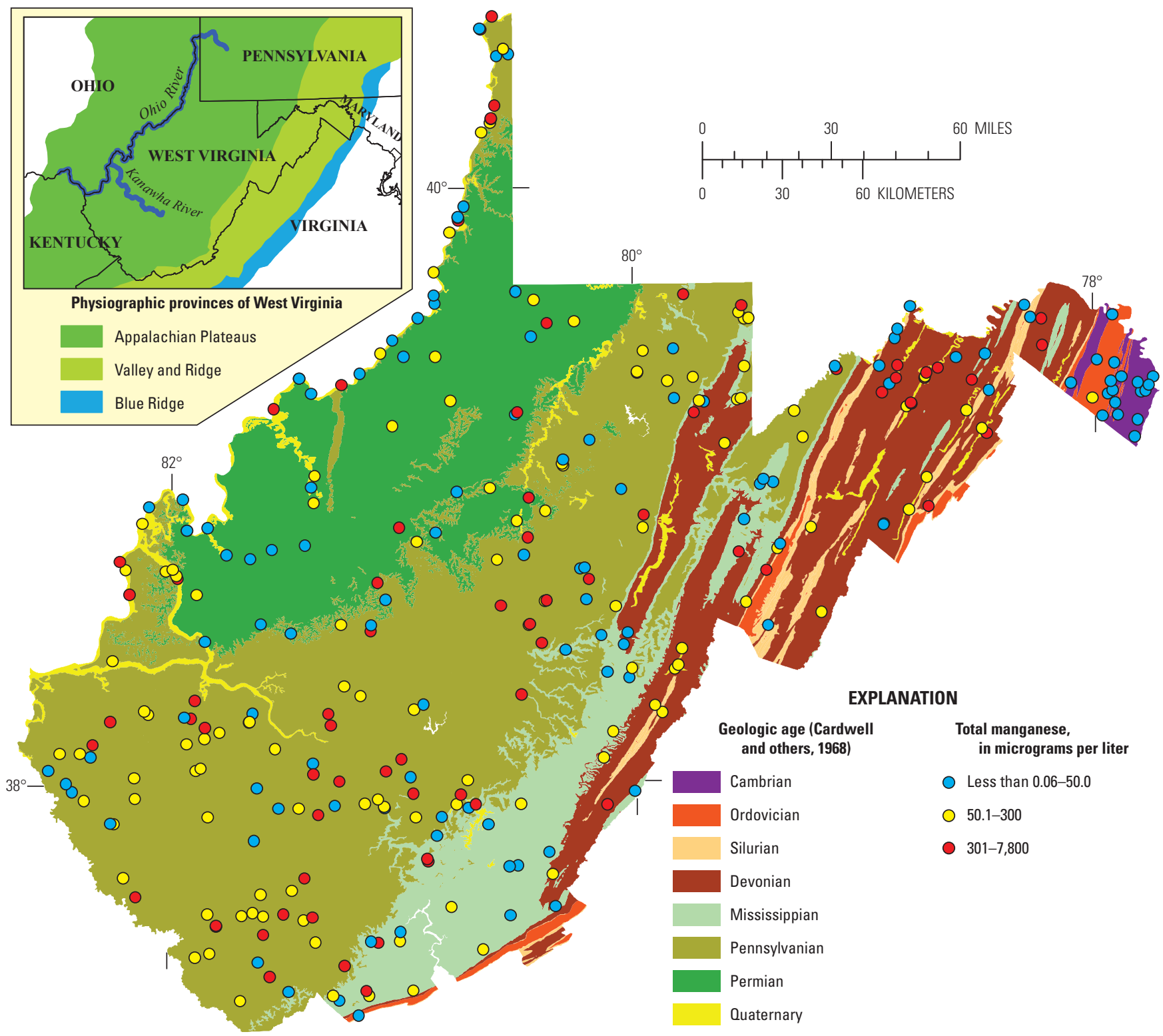

Figure 21. Distribution of groundwater samples from the West Virginia ambient monitoring network analyzed for total manganese, 1993-2008. Samples exceeding the U.S. Environmental Protection Agency (2009b) secondary maximum contaminant level of 50 micrograms $(\mu \mathrm{g} / \mathrm{L}$ ) are in yellow; samples exceeding the health-based screening level (Toccalino and others, 2008) of $300 \mu \mathrm{g} / \mathrm{L}$ are in red. 
62 percent, had no detectable lead $(<0.06 \mu \mathrm{g} / \mathrm{L})$, and 90 percent of samples had concentrations less than $1.8 \mu \mathrm{g} / \mathrm{L}$. The $15 \mu \mathrm{g} / \mathrm{L}$ action level, a concentration requiring use of additional treatment techniques if found in more than 10 percent of samples, for lead was exceeded in four samples in concentrations ranging from 17 to $71 \mu \mathrm{g} / \mathrm{L}$.

\section{Zinc}

Zinc occurs in the Earth's crust at approximately the same abundance as copper and nickel but is more soluble than either of those metals (Hem, 1985). Zinc is widely used in metallurgy, as a component of brass and bronze, and to prevent corrosion through galvanizing. These and other uses contribute to the wide distribution of zinc in the environment. The use of brass, bronze, and galvanized plumbing fixtures can result in zinc entering water-supply systems. The USEPA has established a SMCL of 5,000 $\mu \mathrm{g} / \mathrm{L}$ for zinc, the threshold concentration above which most people can sense a metallic taste due to zinc (U.S. Environmental Protection Agency, $2009 b)$. In addition to the USEPA SMCL, there is a HBSL of 2,000 $\mu \mathrm{g} / \mathrm{L}$ for zinc (Toccalino and others, 2008); high zinc consumption by humans can result in systemic effects, primarily affecting the balance of another essential micronutrient, copper (U.S. Environmental Protection Agency, 2005).
Zinc concentrations ranged from less than the method reporting level of $1 \mu \mathrm{g} / \mathrm{L}$ to $9,810 \mu \mathrm{g} / \mathrm{L}$ with a median concentration of $6 \mu \mathrm{g} / \mathrm{L}$ (table 5). Concentrations in most of the samples, 80 percent, ranged from less than the detection level to $89.2 \mu \mathrm{g} / \mathrm{L}$. Concentrations of zinc did not differ significantly $(p=0.92)$ with the geologic age of the aquifer (fig. 22). Less than 2 percent of samples exceeded established criteria. Five samples exceeded the HBSL of 2,000 $\mu \mathrm{g} / \mathrm{L}$, and one sample exceeded the 5,000 $\mu \mathrm{g} / \mathrm{L}$ SMCL.

\section{Barium}

Barium is a relatively abundant element; the dissolution of the common mineral barite is the chief source of barium in water (Hem, 1985). High concentrations of barium can contribute to high blood pressure, leading the USEPA to establish a MCL of 2,000 $\mu \mathrm{g} / \mathrm{L}$ (U.S. Environmental Protection Agency, 2009b). Additionally, both the USEPA (2012) and the World Health Organization (2006) have established criteria at $700 \mu \mathrm{g} / \mathrm{L}$, the former a drinking-water advisory for consumption by a $10-\mathrm{kg}$ child and the latter as a general drinking-water guideline. In this survey, barium concentrations ranged from $1.6 \mu \mathrm{g} / \mathrm{L}$ to $7,430 \mu \mathrm{g} / \mathrm{L}$ (table 5); the median barium concentration was $138 \mu \mathrm{g} / \mathrm{L}$. Barium concentrations in most of the samples were from $37 \mu \mathrm{g} / \mathrm{L}$ to $732 \mu \mathrm{g} / \mathrm{L}$. However,

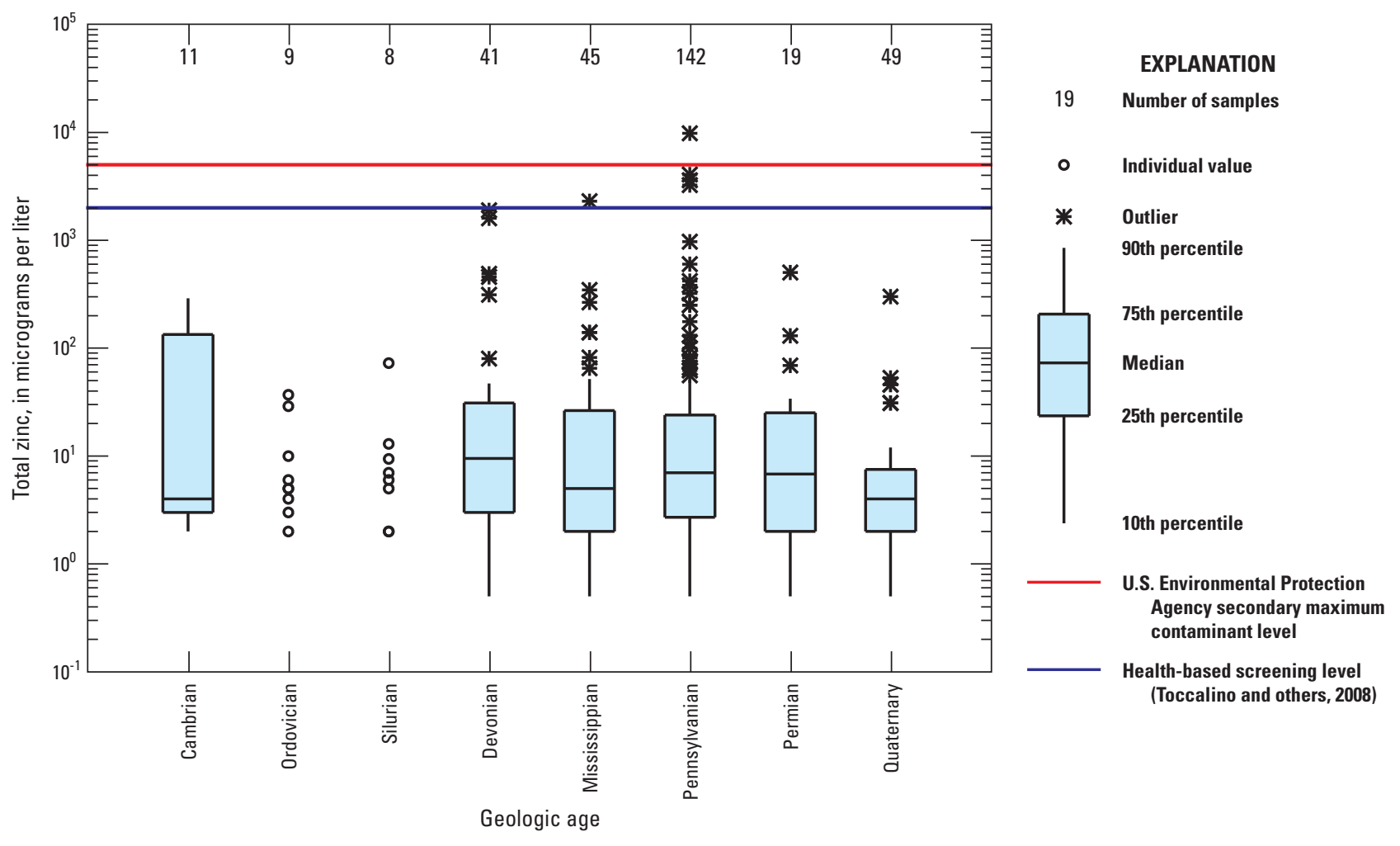

Figure 22. Distribution of zinc concentrations in groundwater samples from the West Virginia ambient monitoring network, grouped by geologic age of the aquifers, 1993-2008. The red line denotes the U.S. Environmental Protection Agency (2009b) secondary maximum contaminant level of 5,000 micrograms per liter $(\mu \mathrm{g} / \mathrm{L})$; the blue line denotes a health-based screening level (Toccalino and others, 2008) of 2,000 $\mu \mathrm{g} / \mathrm{L}$. 
six samples, five from Pennsylvanian aquifers and one from a Quaternary aquifer, exceeded the 2,000 $\mu \mathrm{g} / \mathrm{L} \mathrm{MCL}$ (fig. 23).

Barium concentrations differed significantly among geologicage classes (fig. 24). The lowest median concentrations were in samples from Quaternary aquifers, and the highest median concentrations were in samples from Permian aquifers (Kruskal-Wallis rank sum test $\mathrm{p}$-value $<0.001$ ).

\section{Radon-222}

Radon-222, a radioactive gas that is a decay product of uranium, can be given off by groundwater as it exits spigots or showerheads and can accumulate in air to high levels in homes; exposure to high levels of radon can increase the risk of lung cancer. The USEPA has proposed a two-tiered, radon-222 drinking-water regulation, a $300 \mathrm{pCi} / \mathrm{L} \mathrm{MCL}$ or a $4,000 \mathrm{pCi} / \mathrm{L}$ alternate MCL that will be coupled with a multimedia mitigation program to reduce indoor air radon concentrations (U.S. Environmental Protection Agency, 1999).

Radon-222 was detected in all but two samples, in concentrations ranging from below the reporting limit (10$30 \mathrm{pCi} / \mathrm{L})$ to $3,330 \mathrm{pCi} / \mathrm{L} ; 45$ percent of the samples exceeded the proposed MCL $(300 \mathrm{pCi} / \mathrm{L})$. The median value for all samples was $260 \mathrm{pCi} / \mathrm{L}$; most of the values fell between 40 and $1,260 \mathrm{pCi} / \mathrm{L}$. Distinct patterns in radon concentrations in relation to the geologic age of the aquifer were apparent (fig. 25). The median values for Cambrian, Permian, and

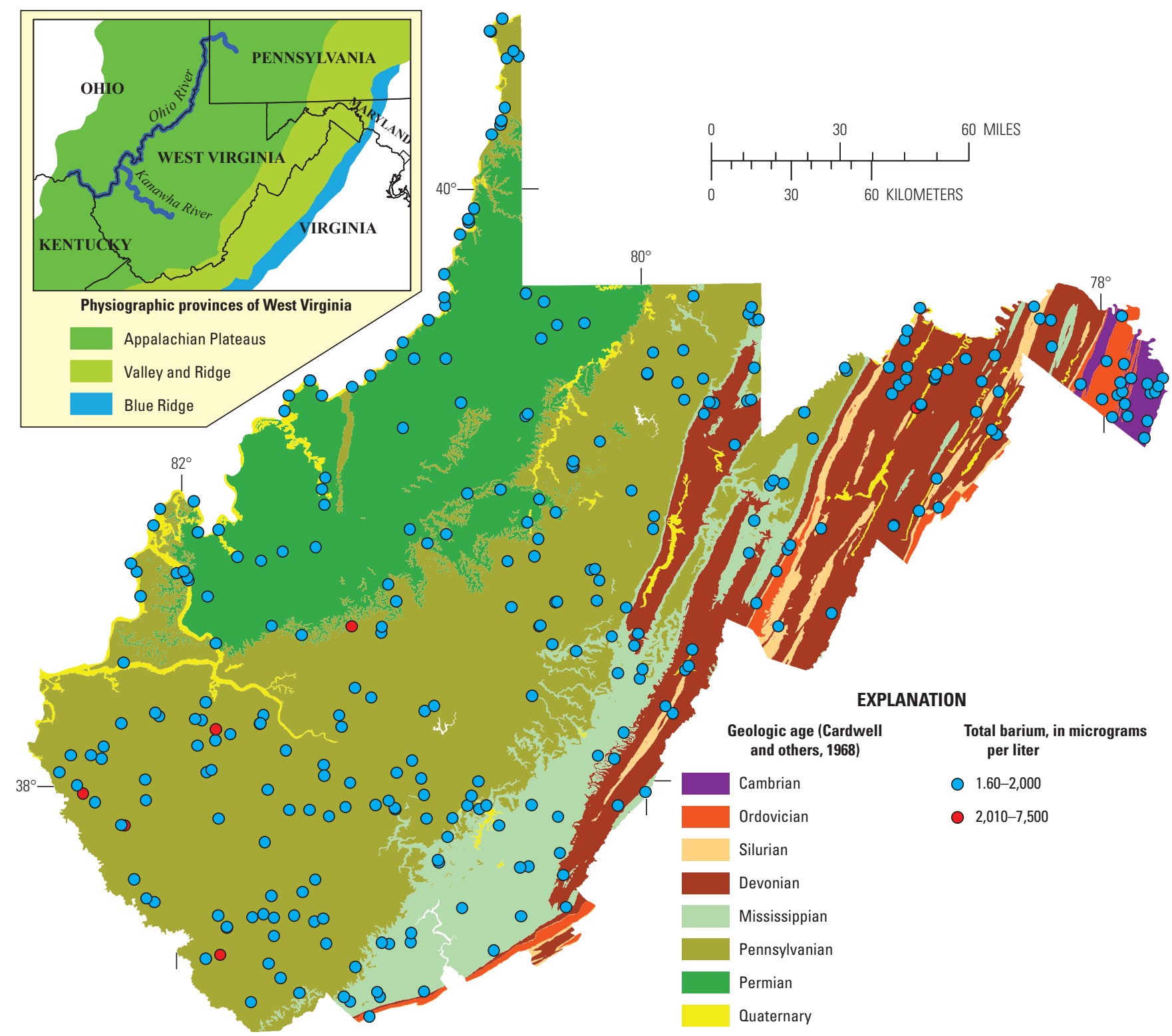

Figure 23. Distribution of groundwater samples from the West Virginia ambient monitoring network analyzed for total barium, 1993-2008. Samples exceeding the U.S. Environmental Protection Agency (2009b) maximum contaminant level of 2,000 micrograms per liter are in red. 


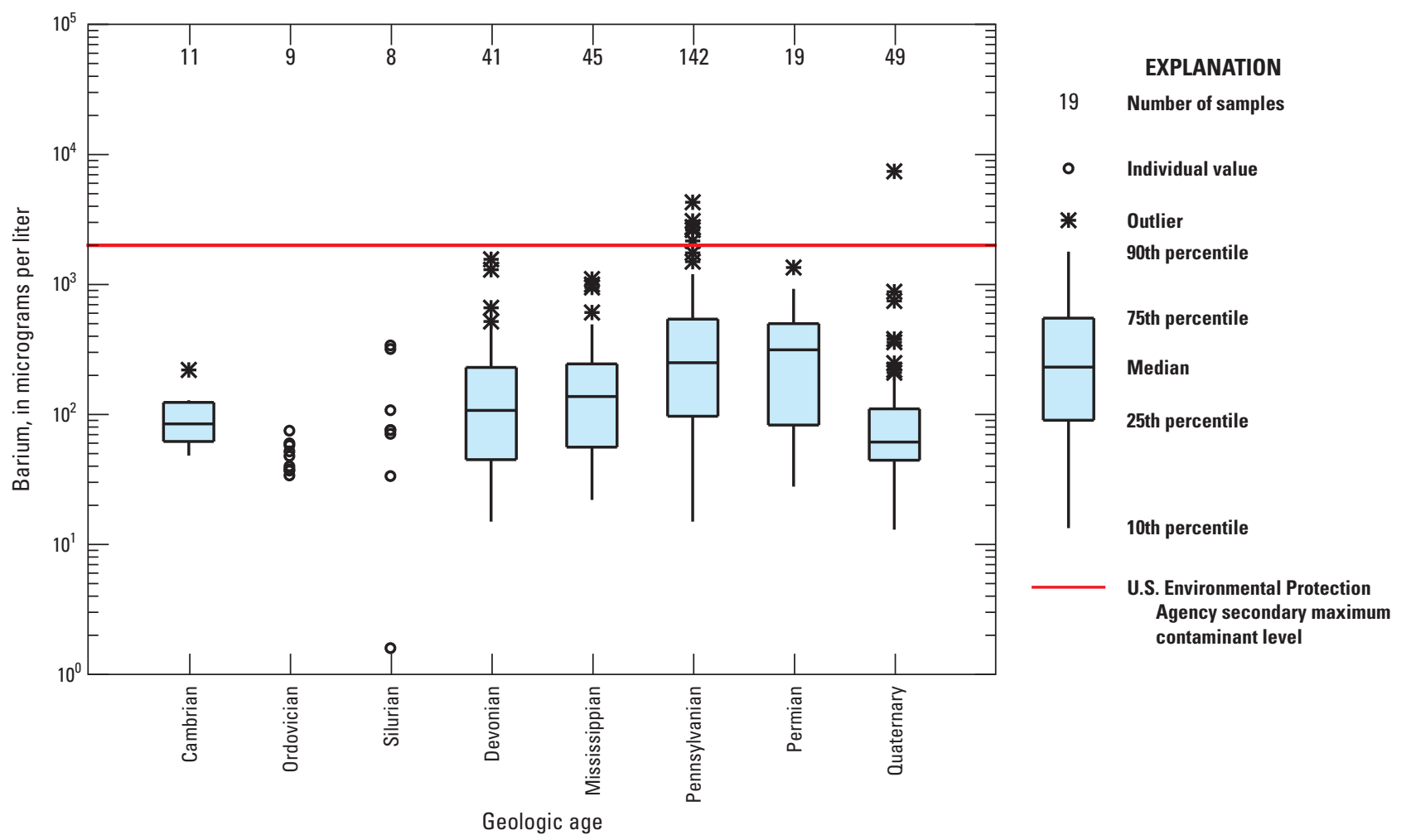

Figure 24. Distribution of barium concentrations in groundwater samples from the West Virginia ambient monitoring network, grouped by geologic age of the aquifers, 1993-2008. The red line denotes the U.S. Environmental Protection Agency (2009b) secondary maximum contaminant level for finished drinking water of 2,000 micrograms per liter.

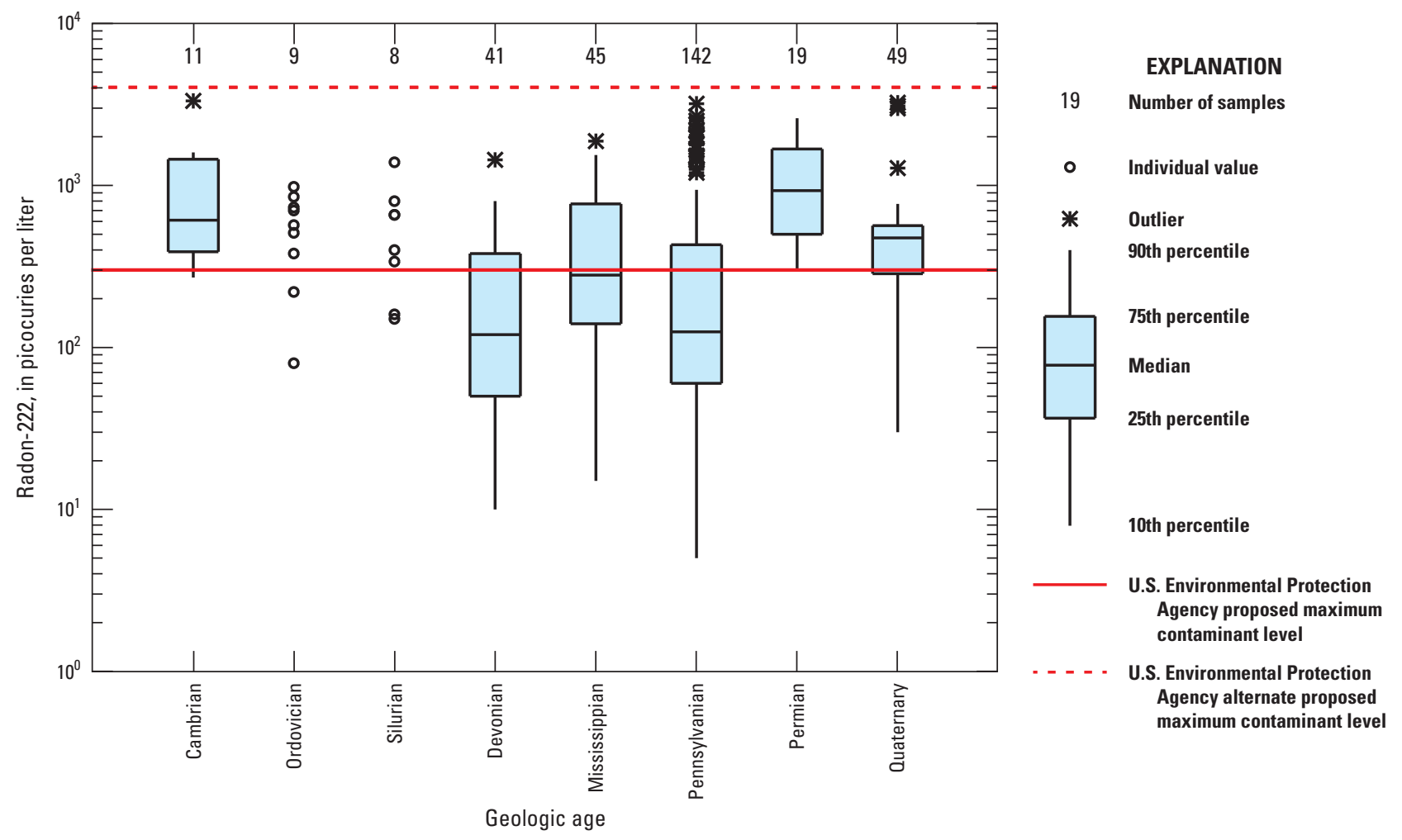

Figure 25. Distribution of radon-222 in groundwater samples from the West Virginia ambient monitoring network, grouped by geologic age, 1993-2008. The solid red line denotes the proposed U.S. Environmental Protection Agency (1999) maximum contaminant level of 300 picocuries per liter (pCi/L); the broken red line indicates the alternate proposed maximum contaminant level of $4,000 \mathrm{pCi} / \mathrm{L}$ with multimedia mitigation program. 
Quaternary aquifers exceeded the $300 \mathrm{pCi} / \mathrm{L}$ MCL. Although median radon concentrations for wells in Devonian, Mississippian, and Pennsylvanian aquifers were less than the $300 \mathrm{pCi} / \mathrm{L}$ $\mathrm{MCL}$, radon concentrations greater than the MCL were measured in samples from aquifers of all geologic-age classes (fig. 26).

The highest radon-222 concentration detected $(3,330 \mathrm{pCi} / \mathrm{L})$ was in a sample from a Cambrian aquifer in the Blue Ridge Physiographic Province in the extreme eastern edge of the Eastern Panhandle, an environmental setting for which sparse data on the occurrence and distribution of radon are available. The radon-222 concentration for the only other sample from that area was $690 \mathrm{pCi} / \mathrm{L}$. These high concentrations and high concentrations documented by investigations in other parts of the Blue Ridge (Kozar and others, 2001) indicate that further sampling is needed to determine whether residents of this area are more likely to encounter groundwater with radon concentrations in excess of the proposed alternate maximum contaminant level of $4,000 \mathrm{pCi} / \mathrm{L}$ and might benefit from testing of indoor air and well water for radon-222.

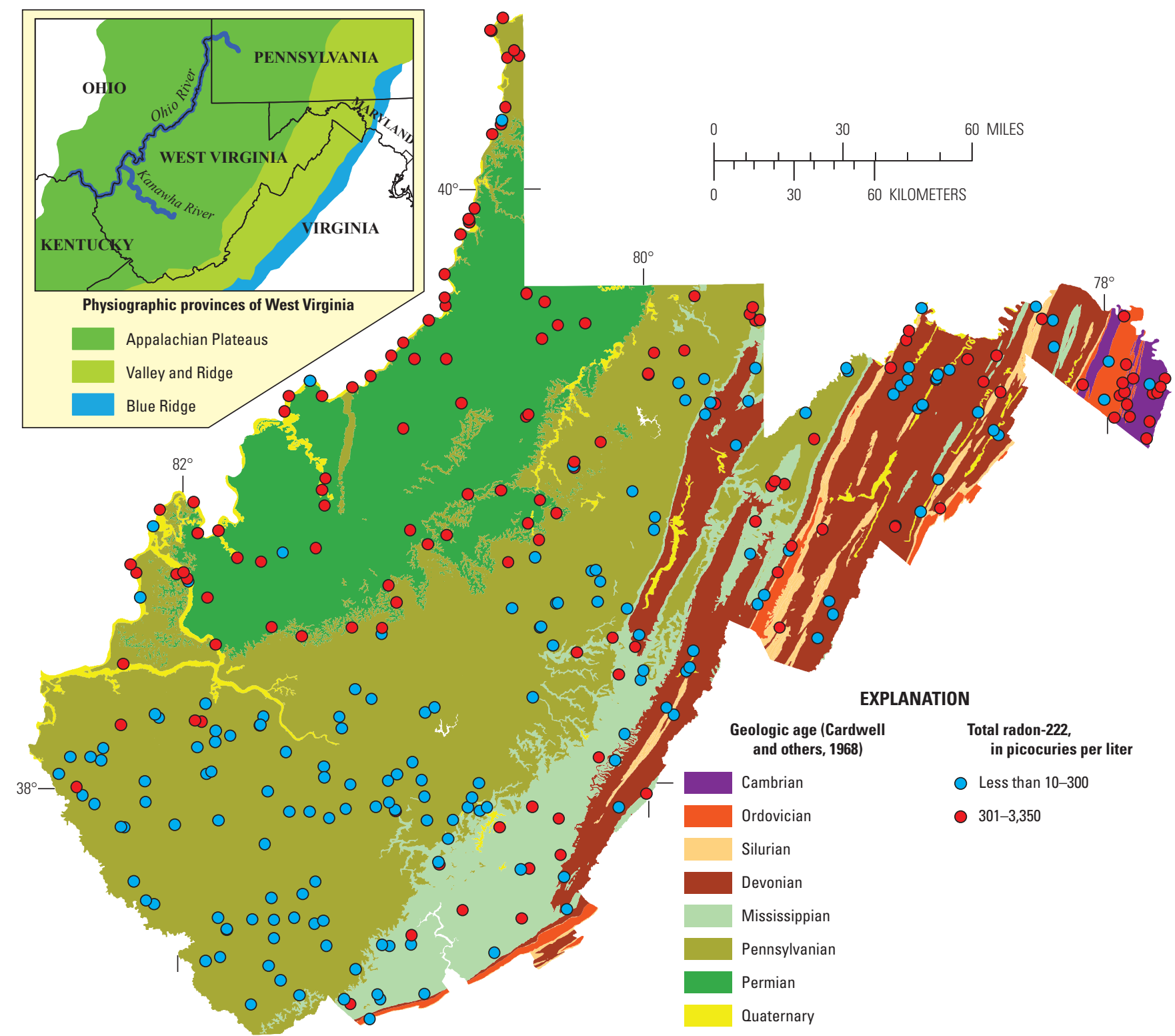

Figure 26. Distribution of groundwater samples from the West Virginia ambient monitoring network analyzed for radon-222, 1993-2008. Samples exceeding the proposed U.S. Environmental Protection Agency (1999) maximum contaminant level of 300 picocuries per liter are in red. 


\section{Organic Compounds}

The wide use of anthropogenic organic compounds in transportation, industrial processes, agriculture, and household products has provided multiple routes for these compounds to enter the environment. Organic compounds were grouped in three classes - two based on physical properties (volatile and semi-volatile organic compounds) and one based on use (pesticides). Volatile organic compounds (VOCs) typically have low vapor pressure and, in open systems, quickly disperse to the atmosphere. VOCs include solvents, fuel and fuel additives, and compounds used in industrial processes and chemical manufacturing (Zogorski and others, 2006). Semivolatile organic compounds, as the name implies, have lower volatilities and disperse to the atmosphere more slowly than VOCs. This group also includes various solvents, compounds used in industrial processes, and compounds that result from industrial processes, as well as polycyclic aromatic hydrocarbons (PAHs). PAHs are present in coal and oil but are also the result of combustion. The third class discussed, pesticides, are compounds used to kill unwanted organisms - plants, insects, or rodents, for example.

\section{Volatile Organic Compounds}

Of the 34 VOCs analyzed for, 25 were detected in at least one sample (table 6). In nearly 60 percent of samples in which VOCs were detected, only one compound was found. The number of VOCs found in the remaining 40 percent of samples ranged from two to nine. The two most frequently detected VOCs were trichloromethane, more commonly known as chloroform, and MTBE, an oxygenate added to gasoline to improve combustion efficiency. These compounds were also the two most frequently detected in a nationwide study of VOCs in groundwater (Zogorski and others, 2006).

The USEPA has established drinking-water criteria for 12 of the 25 VOCs detected. Only two VOCs, benzene and vinyl chloride, were detected in concentrations exceeding their MCLs, 5 and $2 \mu \mathrm{g} / \mathrm{L}$, respectively (U.S. Environmental Protection Agency, 2009b). Concentrations of benzene, a known carcinogen used as a gasoline additive and industrial solvent, exceeded the MCL of $5 \mu \mathrm{g} / \mathrm{L}$ (U.S. Environmental Protection Agency, 2009b) in two samples, at $9.39 \mu \mathrm{g} / \mathrm{L}$ and $6.38 \mu \mathrm{g} / \mathrm{L}$. Vinyl chloride, a precursor compound in plastics manufacturing and a component of polyvinyl chloride pipe, was found to exceed the MCL in one sample with a concentration of $8.8 \mu \mathrm{g} / \mathrm{L}$.

The distribution of VOCs in groundwater is largely the result of two factors - source and susceptibility. The number of VOCs detected in a sample was highest in alluvial and limestone settings (fig. 27), settings that are particularly susceptible to rapid transport of contaminants to groundwater (McCoy and Kozar, 2007). Proximity to a source of VOCs also figures
Table 6. Volatile organic compounds analyzed for in groundwater samples from West Virginia ambient monitoring network, 1993-2008.

[Compounds detected in at least one sample are in bold.]

\begin{tabular}{|c|c|c|}
\hline Constituent & $\begin{array}{c}\text { Method } \\
\text { reporting level, } \\
\text { in micrograms } \\
\text { per liter }\end{array}$ & $\begin{array}{l}\text { Number of } \\
\text { detections }\end{array}$ \\
\hline Benzene & 0.1 & 3 \\
\hline Chlorobenzene & 0.1 & 3 \\
\hline Ethylbenzene & 0.1 & 1 \\
\hline 1,3-Dichlorobenzene & 0.1 & 0 \\
\hline 1,2-Dichlorobenzene & 0.1 & 0 \\
\hline 1,4-Dichlorobenzene & 0.1 & 1 \\
\hline Bromoform & 0.2 & 4 \\
\hline Tetrachloromethane & 0.2 & 1 \\
\hline Chloroform & 0.1 & 25 \\
\hline 1,1,1-Trichloroethane & 0.1 & 7 \\
\hline 1,1,2-Trichlorotrifluoroethane & 0.1 & 2 \\
\hline 1,2-Dichloroethane & 0.2 & 0 \\
\hline Diethyl ether & 0.2 & 2 \\
\hline Ethyl tert-butyl ether & 0.1 & 0 \\
\hline cis-1,2-Dichloroethylene & 0.1 & 4 \\
\hline Tetrachloroethylene & 0.1 & 5 \\
\hline trans-1,2-Dichloroethylene & 0.1 & 0 \\
\hline Trichloroethylene & 0.1 & 9 \\
\hline 1,1-Dichloroethane & 0.1 & 5 \\
\hline Diisopropyl ether & 0.2 & 6 \\
\hline m- and p-Xylene & 0.2 & 3 \\
\hline Bromodichloromethane & 0.1 & 7 \\
\hline Dibromochloromethane & 0.2 & 5 \\
\hline Dichlorodifluoromethane & 0.2 & 0 \\
\hline Trichlorofluoromethane & 0.2 & 0 \\
\hline tert-Butyl methyl ether & 0.2 & 22 \\
\hline Dichloromethane & 0.2 & 0 \\
\hline o-Xylene & 0.1 & 1 \\
\hline 1,2-Dichloropropane & 0.1 & 0 \\
\hline Styrene & 0.1 & 1 \\
\hline tert-Pentyl methyl ether & 0.2 & 2 \\
\hline Toluene & 0.1 & 8 \\
\hline Vinyl chloride & 0.2 & 2 \\
\hline 1,1-Dichloroethylene & 0.1 & 2 \\
\hline
\end{tabular}


in the distribution of VOCs. Several of the sites where VOCs were detected were near known sources of VOCs, including documented spills, underground gasoline storage tanks, or industrial areas.

\section{Semi-Volatile Compounds}

The limited set of semi-volatile compound data, 18 samples collected during 2005-08, indicate that these compounds infrequently contaminate groundwater in West Virginia. Of the 57 semi-volatile compounds for which samples were analyzed (table 7), only two, phenol and phenanthrene, were detected, and those were found at the threshold of detection. Phenol concentrations were detected in two wells in an industrialized area of the Ohio River alluvial aquifer, and both were estimated values, 0.1 and $0.3 \mu \mathrm{g} / \mathrm{L}$. The presence of phenanthrene was verified in a well at an industrial site, but the concentration was too small to be quantified.

\section{Pesticides}

Pesticides were analyzed in 77 selected samples, typically from agricultural settings where pesticide use is greatest. Samples were analyzed for a suite of 52 pesticides (table 8), primarily herbicides and insecticides, of which 12 were detected. At least one pesticide was detected in 22 of the 77 samples for which pesticide analyses were conducted. Drinking-water criteria exist for 11 of the 12 detected compounds-2 MCLs and 9 HBSLs. Of the pesticides with drinking-water criteria, none were detected in concentrations exceeding the criteria. The two most commonly detected pesticides were deethylatrazine, a breakdown product of the herbicide atrazine, and atrazine itself, which were found in 16 and 15 samples, respectively. Most of the samples, 16 of 22 , in which pesticides were detected contained detectable concentrations of 2 or more pesticides with as many as 7 pesticides or pesticide degradates detected in one sample.

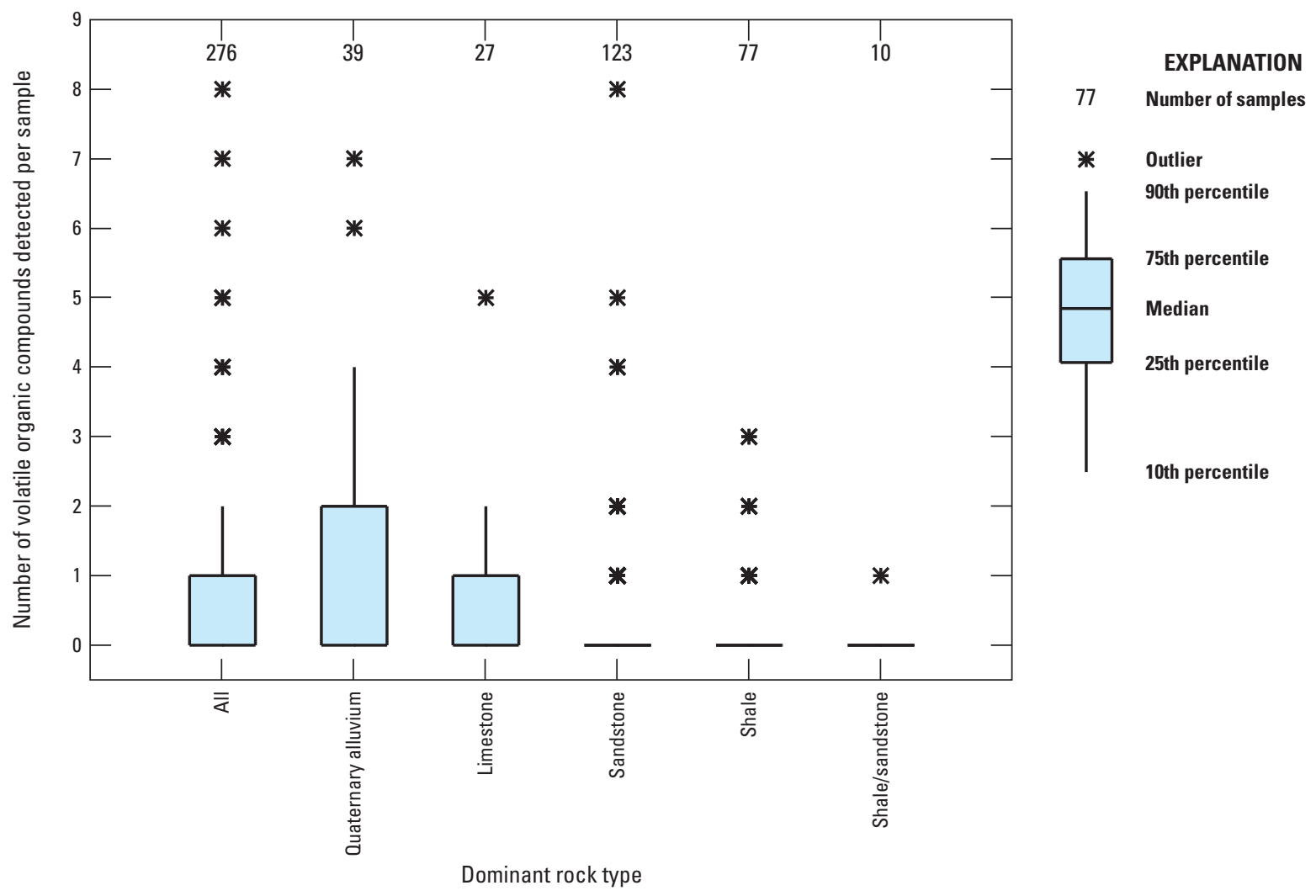

Figure 27. Distribution of the number of volatile organic compounds detected per groundwater sample from the West Virginia ambient monitoring network, grouped by dominant rock type, 1993-2008. 
Table 7. Semi-volatile organic compounds analyzed for in selected groundwater samples from the West Virginia ambient monitoring network, 1993-2008.

[Compounds detected in at least one sample are in bold.]

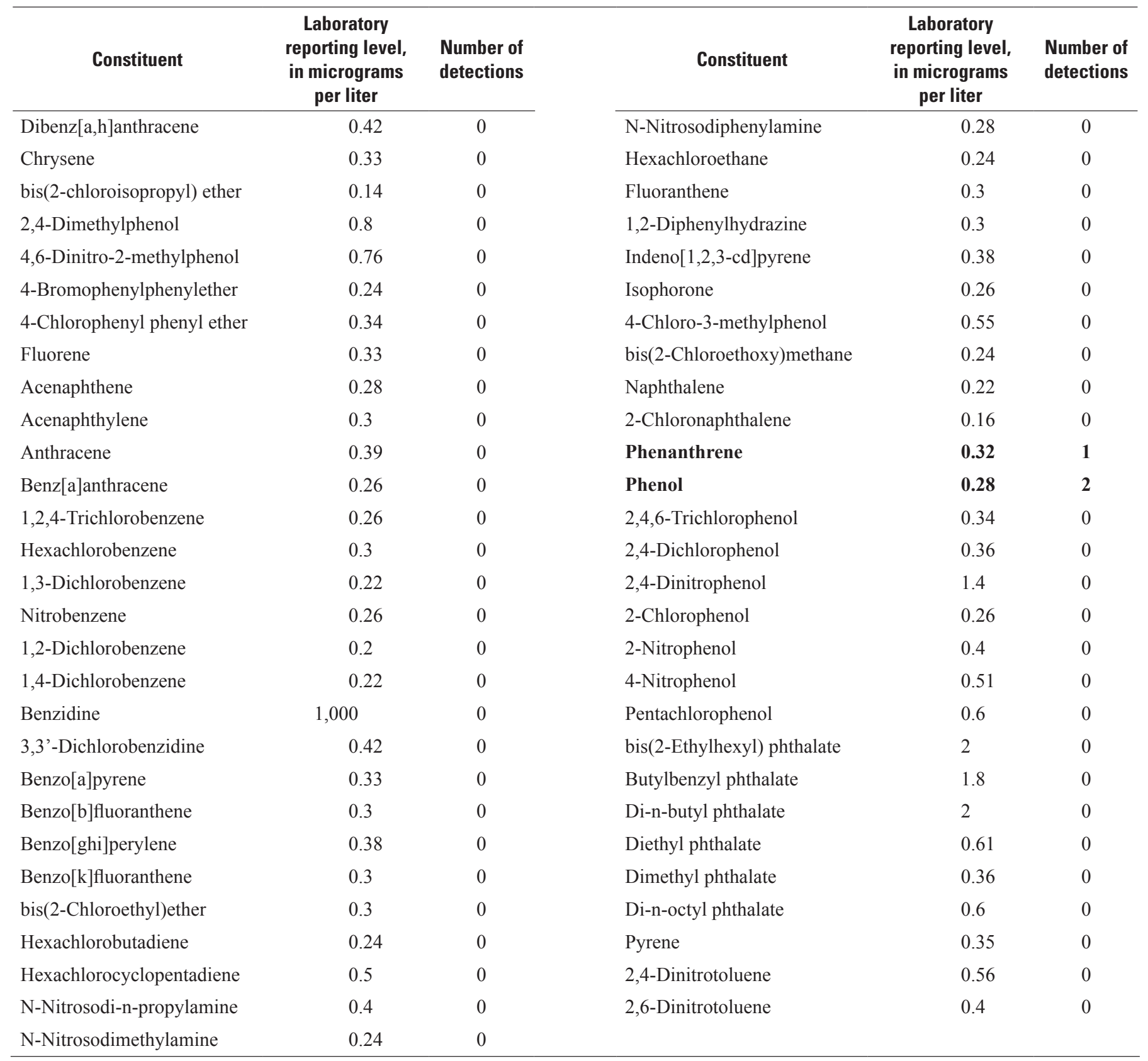


Table 8. Pesticides and pesticide degradates analyzed for in 77 groundwater samples from the West Virginia ambient monitoring network, 1993-2008.

[Compounds detected in at least one sample are in bold. HCH, hexachlorocyclohexane; EPTC, S-ethyl dipropyl(thiocarbamate); DDE, 1,1-bis(4-chlorophenyl)-2,2-dichloroethene]

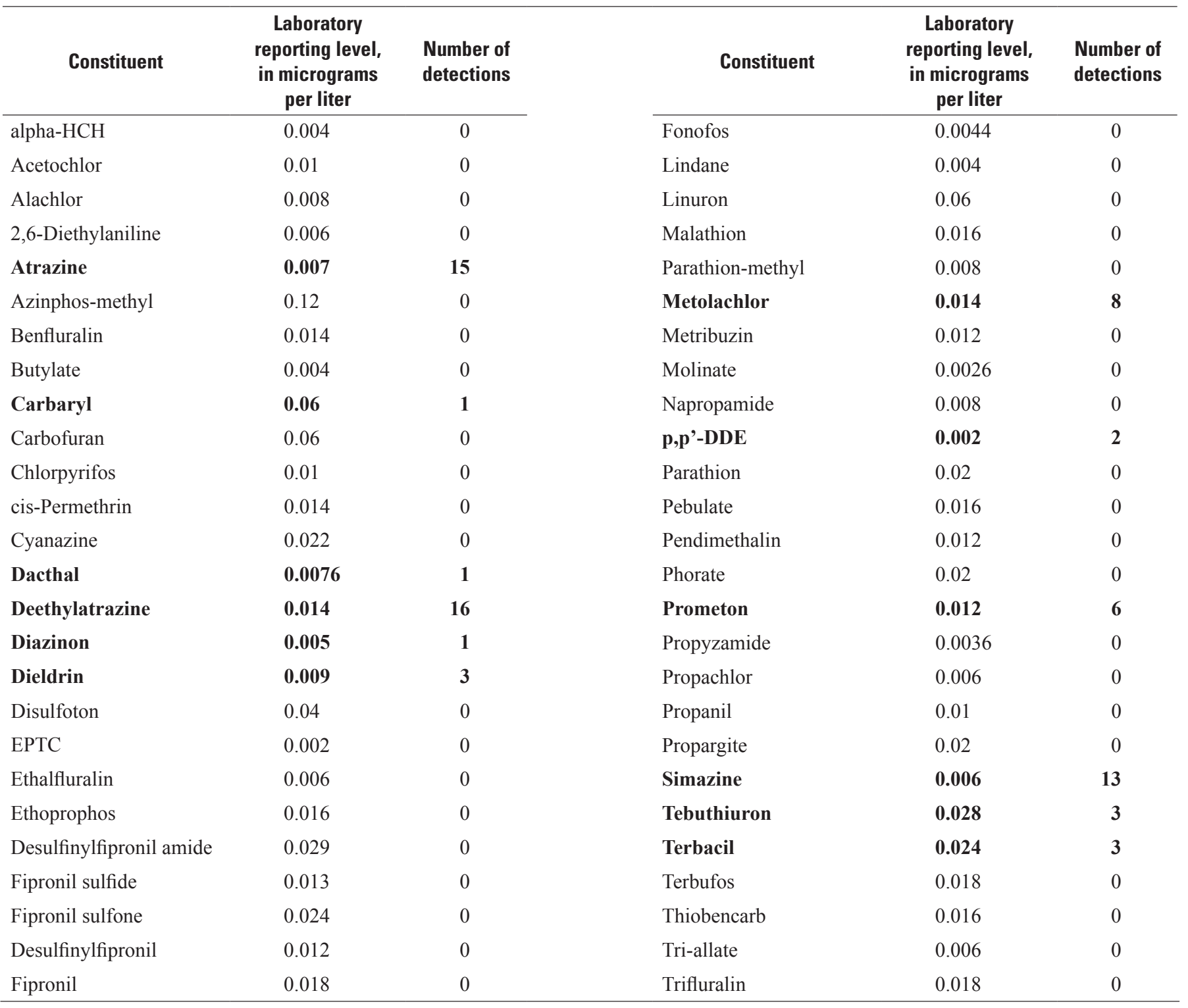


The pesticide results display a spatial pattern of pesticide occurrence in groundwater (fig. 28), although the purposeful selection of sites in areas of expected pesticide occurrence likely influenced the pattern. Groundwater in limestonedominated areas most frequently contained greater numbers of pesticides detected (fig. 29). As with the occurrence of VOCs in groundwater, groundwater contamination by pesticides is a product of source and susceptibility. Agricultural lands in West Virginia, where pesticide use is heaviest in the State, are concentrated in limestone-dominated areas. These are also areas where surface runoff quickly infiltrates to the water table. Although many of the wells in the limestone-dominated areas were not on agricultural lands, the high transmissivity of Karstic limestone aquifers allows for the rapid movement of contaminants to nearby areas. This condition of high pesticide use in areas where surface-water/groundwater connectivity is high makes West Virginia's limestone-dominated areas especially susceptible to pesticide contamination.

\section{Relations Among Water-Quality Characteristics and Environmental Settings}

Groundwater quality can be affected by environmental settings, including the local geology that affects geochemical processes, topography, land cover, and population density. Well-construction characteristics, including well depth, casing length, casing material, and well grouting, also can affect the quality of groundwater samples. PCA was used to evaluate the role these factors play in contributing to the water quality of the sampled wells.

Geochemical processes were evaluated by examining elemental loadings computed for the first two principle components. The first principal component accounted for 22 percent of the variance in the data, and the second principal

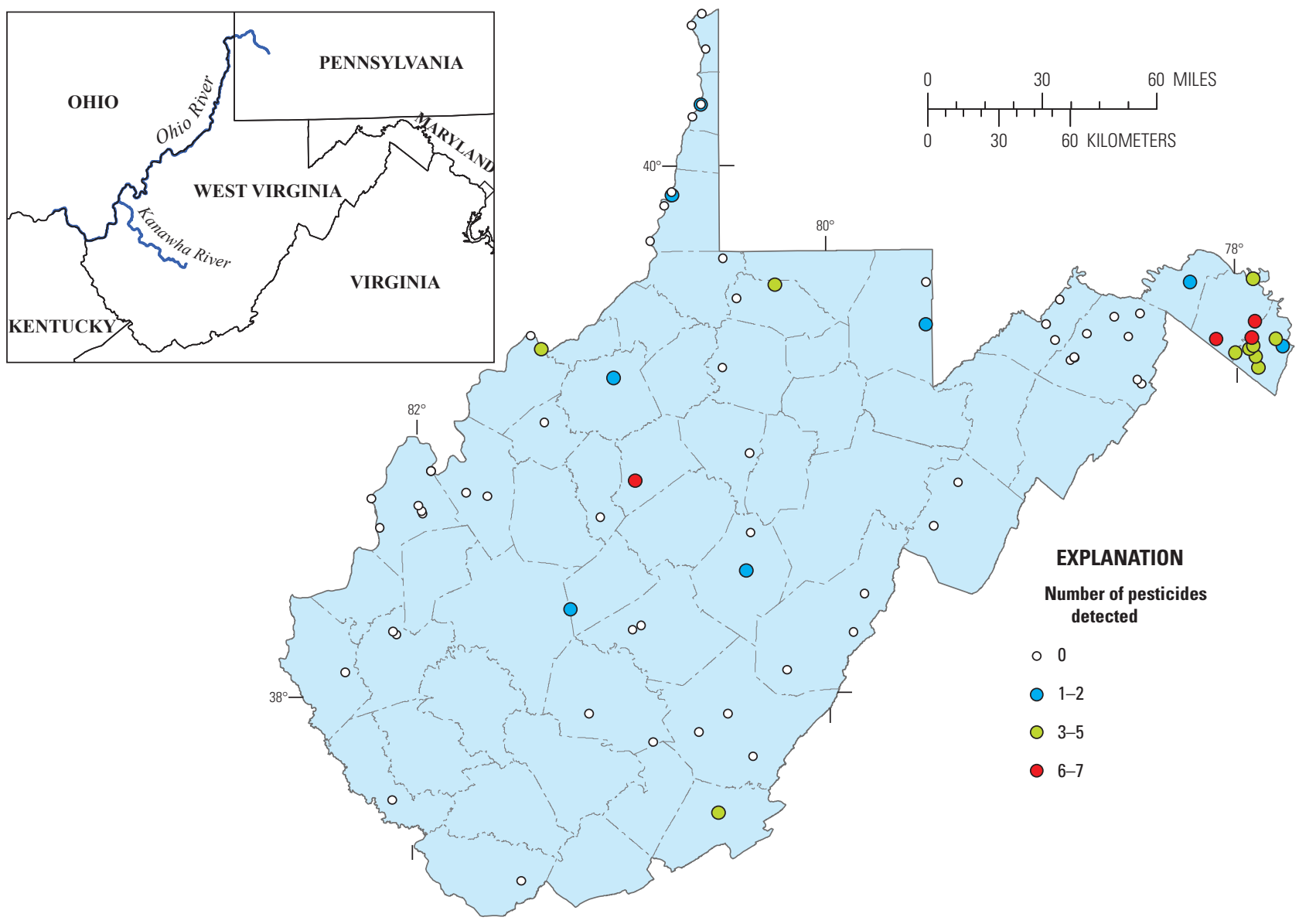

Figure 28. Distribution of samples from the West Virginia ambient monitoring network analyzed for pesticides and the number of pesticides detected per groundwater sample, 1993-2008. 


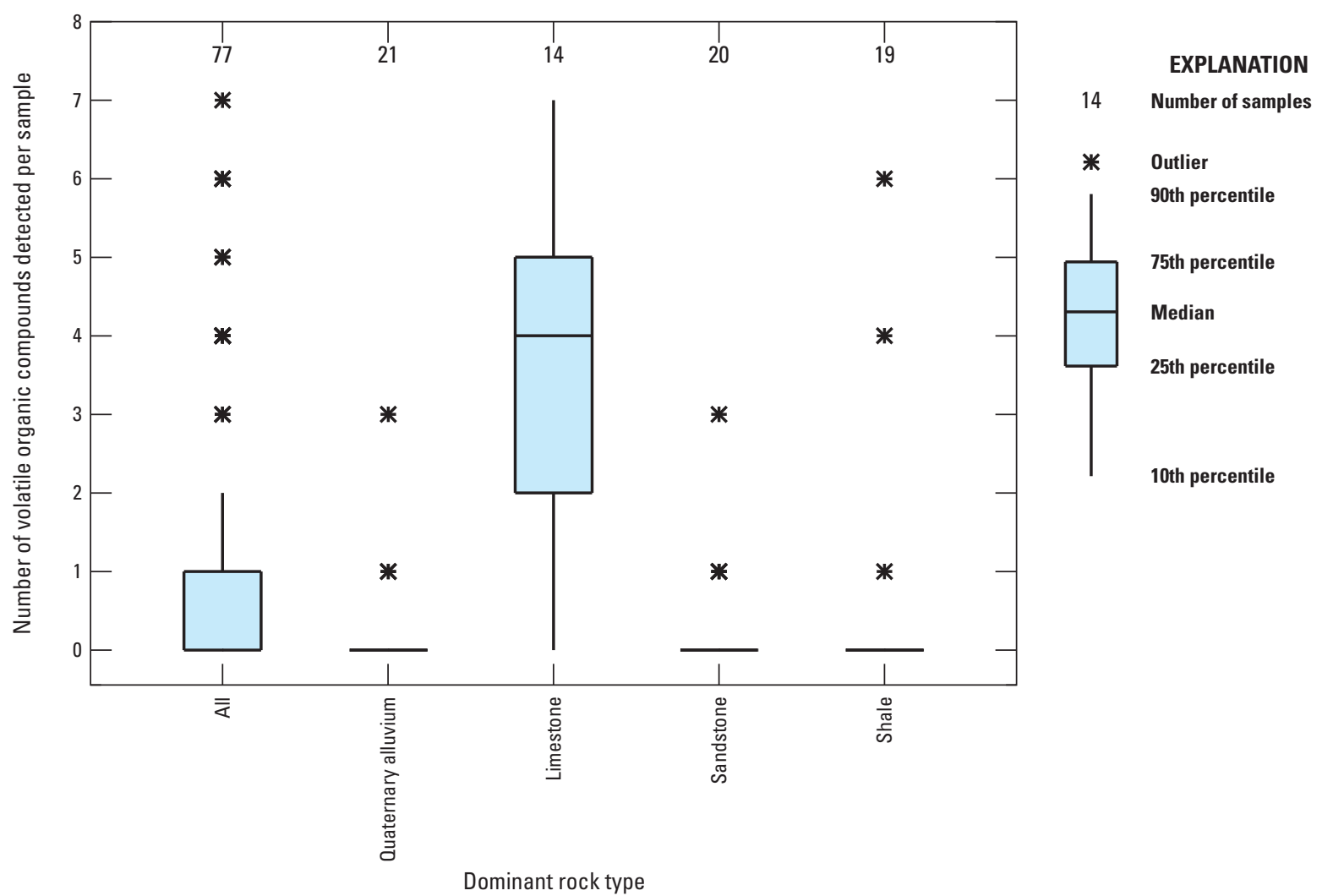

Figure 29. Distribution of the number of pesticides detected per groundwater sample from the West Virginia ambient monitoring network, grouped by dominant rock type, 1993-2008.

component accounted for an additional 18 percent variance in the data set. The first principal component (principal component 1 in table 9) showed strong negative eigenvector loadings for calcium, magnesium, potassium, sodium, bicarbonate, bromide, chloride, and sulfate, with total dissolved solids, indicating these constituents are the primary constituents responsible for the variance in total dissolved solids content in groundwater from the sampled wells. The second principal component (principal component 2 in table 9) showed strong negative eigenvector loadings for calcium, magnesium, sulfate, manganese, and zinc and strong positive eigenvector loadings for sodium, chloride, bromide, and bicarbonate, indicating cation exchange processes occurred at boundaries between shallow calcium/magnesium water types and deeper sodium/chloride type waters.

No statistically significant relation between groundwater quality and well depth or groundwater quality and topographic setting (hilltop, hillside, or valley) was discerned in this analysis, although such relations were reported in an earlier analysis of domestic wells in West Virginia (Mathes and others, 1998). The absence of relations among groundwater quality, well depth, or topographic setting in this present analysis is likely attributable primarily to sampling public-supply wells, whereas Mathes and others (1998) sampled domestic wells. Public-supply wells are typically pumped at higher rates and for much longer periods than domestic wells, which can result in cones of depression in the water table that contribute to differences in the origin of pumped water. Public-supply wells are more likely to receive ground-water recharge from a much broader area than domestic wells. Lastly, the population of hilltop wells is very small, 29 of 324 . These differences tend to mask the effects of topography and well depth in public-supply wells, although the effects of these settings were readily apparent in domestic wells in the earlier study by Mathes and others (1998).

\section{Implications for Further Studies of West Virginia Groundwater Resources}

Although this report presents the most comprehensive statewide analysis of groundwater quality to date, many questions remain to be answered. The ambient groundwater 
Table 9. Principal components analysis showing distribution of eigenvector loadings for the first two principal components for samples from the West Virginia ambient monitoring network, 1993-2008.

$[\mathrm{mg} / \mathrm{L}$, milligram per liter; $\mu \mathrm{g} / \mathrm{L}$, microgram per liter; $\mathrm{N}$, nitrogen; $\mathrm{pCi} / \mathrm{L}$, picocuries per liter; nsr, indicates that the eigenvector loading computed was small and not statistically significant $(\mathrm{p}>0.05)$ to the analysis]

\begin{tabular}{lcc}
\hline \multicolumn{1}{c}{ Constituent } & Component 1 & Component 2 \\
\hline Dissolved oxygen, mg/L & 0.154 & -0.158 \\
Calcium, mg/L & -0.315 & -0.334 \\
Magnesium, mg/L & -0.308 & -0.369 \\
Potassium, mg/L & -0.243 & $\mathrm{nsr}$ \\
Sodium, mg/L & -0.284 & 0.375 \\
Bicarbonate, mg/L & -0.309 & 0.208 \\
Bromide, mg/L & -0.256 & 0.348 \\
Chloride, mg/L & -0.264 & 0.354 \\
Sulfate, $\mathrm{mg} / \mathrm{L}$ & -0.341 & -0.333 \\
Total dissolved solids (residue & -0.472 & $\mathrm{nsr}$ \\
$\quad$ on evaporation), mg/L & & \\
Aluminum, $\mu \mathrm{g} / \mathrm{L}$ & $\mathrm{nsr}$ & $\mathrm{nsr}$ \\
Arsenic, $\mu \mathrm{g} / \mathrm{L}$ & $\mathrm{nsr}$ & $\mathrm{nsr}$ \\
Barium, $\mu \mathrm{g} / \mathrm{L}$ & 0.177 & -0.112 \\
Iron, $\mu \mathrm{g} / \mathrm{L}$ & $\mathrm{nsr}$ & $\mathrm{nsr}$ \\
Manganese, $\mu \mathrm{g} / \mathrm{L}$ & -0.123 & -0.241 \\
Zinc, $\mu \mathrm{g} / \mathrm{L}$ & -0.171 & -0.241 \\
Radon, $\mathrm{pCi} / \mathrm{L}$ & $\mathrm{nsr}$ & $\mathrm{nsr}$ \\
Phosphorous, mg/L & $\mathrm{nsr}$ & $\mathrm{nsr}$ \\
Nitrate + nitrite, mg/L as N & $\mathrm{nsr}$ & $\mathrm{nsr}$ \\
\hline
\end{tabular}

program was designed to provide a broad assessment of the quality of West Virginia's groundwater. This goal has been achieved. However, to gain a more complete understanding of the resource and the factors affecting groundwater quality, further sampling and studies are needed. Sampling and studies that would provide greater sample density in settings underrepresented in this data set, such as the Permian aquifers of northwest West Virginia, and measurement of more constituents, such as broader suites of pesticides and other organic contaminants in susceptible areas, would advance the understanding of groundwater quality in West Virginia. Sampling and studies to address unanswered or new questions could be designed in such a way as to specifically answer those questions while eliminating environmental noise or confounding influences. It is likely that variability due to factors other than geochemical processes or environmental setting masked many patterns in the data. Selection of sites more closely matched in well construction, withdrawal rates, and pump type also would likely reduce confounding variability.

A refocused sampling effort could clarify some unresolved patterns seen in this analysis, provide information on under-represented areas and settings, or address new questions. Further investigation of geochemical controls on manganese, arsenic, or radon-222 with a study design tailored to these questions would likely increase the understanding of the occurrence and distribution of these constituents in groundwater. For example, the collection of samples in areas with known elevated arsenic concentrations and analysis of the samples for the various arsenic species, with the collection of appropriate supporting data, would allow for the development of models of arsenic risk from groundwater. Collection of data in areas of lower population density, which are areas served by few public-supply wells such as the areas of Permian geology in northwest West Virginia, and, therefore, are sampled less densely, would increase the overall resolution, potentially revealing patterns not seen with current samples. The examination of issues that have yet to be studied or have only recently emerged would provide information not attainable from the current data set. Issues that could be addressed include the effect of injection wells on groundwater quality, the occurrence and distribution of industrial compounds in alluvial aquifers, and the effect of urbanization on groundwater resources.

The aforementioned studies do not include a temporal component on a scale relevant to groundwater. The original network of 26 annually sampled wells was designed, in part, as a trend-detection network. However, a 1-year period between samples is a relatively brief interval for changes in groundwater systems. A network of wells, sampled at a greater interval, can provide consistent data over time. A network of wells, each selected to represent an important environmental setting and sampled at an appropriate temporal scale, would be sufficient to detect broad trends and possibly predict threats to West Virginia's groundwater resources.

\section{Summary and Conclusions}

The variability in the quality of West Virginia's groundwater resources is most strongly affected by geology. Iron in Pennsylvanian bedrock aquifers, the presence of pesticides in limestone-dominated areas, and industrial compounds in Quaternary alluvial aquifers can all be attributed to geologic characteristics, either when the rock acts a as source of the water-quality constituent or when geologic characteristics contribute to aquifer susceptibility to contamination. Although geology exerts the strongest influence on groundwater quality, anthropogenic influences also were noted, primarily the presence of synthetic organic compounds, such as pesticides, and excess nutrients from agricultural activities. Knowledge of these patterns in groundwater quality can be of use to the approximately 42 percent of West Virginians that rely on groundwater for drinking water.

The 324 wells and springs sampled for this study were from a wide variety of environmental settings; samples were from both unconsolidated alluvial aquifers and consolidated 
bedrock aquifers. The consolidated bedrock aquifers sampled ranged in age from Cambrian to Permian. The proportion of samples collected from each setting was not even. The density of sampling was highest in Quaternary alluvial aquifers and Cambrian bedrock aquifers and lowest in Permian bedrock aquifers. Sampling density within an environmental setting was largely a function of population density, which in turn determines well density.

Although this study, conducted by the U.S. Geological Survey in cooperation with the West Virginia Department of Environmental Protection, Division of Water and Waste Management, did not attempt to evaluate finished drinkingwater quality, drinking-water-quality criteria were used as benchmarks against which to compare samples. These criteria are not applicable to the raw-water samples analyzed in this study and are for illustrative purposes only. However, many West Virginians rely on groundwater as a drinking supply, and wells in certain environmental settings may produce water with concentrations of constituents that exceed drinking-water thresholds.

Most samples contained constituent concentrations less than the maximum contaminant levels (MCLs). However, some samples exceeded non-enforceable secondary maximum contaminant levels (SMCLs), proposed MCLs, or advisory health-based screening levels (HBSLs). Radon-222 concentrations exceeded the proposed MCL of 300 picocuries per liter $(\mathrm{pCi} / \mathrm{L})$ in 45 percent of samples, and iron concentrations exceeded the SMCL of 300 micrograms per liter $(\mu \mathrm{g} / \mathrm{L})$ in 57 percent of samples. Manganese concentrations were greater than the SMCL $(50 \mu \mathrm{g} / \mathrm{L})$ in 62 percent of samples and were greater than the HBSL $(300 \mu \mathrm{g} / \mathrm{L})$ in 25 percent of the samples. Other sampled constituents, including organic compounds and trace elements, exceeded drinking-water criteria at much lower frequencies.

The radon-222 median values in samples from Cambrian, Ordovician, Silurian, Permian, and Quaternary aquifers exceeded the proposed 300-pCi/L MCL. Although median radon concentrations for wells in Devonian, Mississippian, and Pennsylvanian aquifers were less than the proposed MCL, radon concentrations greater than the proposed MCL were measured in samples from aquifers of all geologic ages.

The median iron concentrations for samples from Devonian and Pennsylvanian aquifers were greater than the $300 \mu \mathrm{g} / \mathrm{L}$ SMCL. Iron concentrations exceeded the SMCL in aquifers of all geologic ages, except Cambrian. Median concentrations of manganese exceeded the SMCL in samples from Devonian, Pennsylvanian, and Quaternary aquifers. As with iron, manganese concentrations were found to exceed the SMCL in at least one sample from aquifers of all geologic ages, except Cambrian.

The distribution of organic compounds in groundwater is largely the result of two factors - source, such as industrial activity or agriculture, and susceptibility, such as highly transmissive limestone and alluvial settings. Volatile organic compounds (VOCs) were detected with greater frequency in areas dominated by either limestone or alluvium. Alluvial settings, in addition to being highly transmissive, are where the majority of West Virginia's industrial activities are located. Pesticides were detected most frequently and in higher concentrations in limestone-dominated areas. Most of West Virginia's agriculture is concentrated in those areas.

This study is one of the most comprehensive assessments of the water quality of West Virginia's groundwater resources to date. Analysis of these samples from wells and springs across West Virginia provides documentation of relations among groundwater quality and the environmental setting of the wells and springs. This analysis has also identified opportunities to further refine the understanding of groundwater quality in West Virginia, potentially improving the management and protection of this valuable source of drinking water.

\section{References Cited}

American Public Health Association, American Water Works Association, and Water Environment Foundation, 2005a, Enzyme Substrate Coliform Test, Standard methods for the examination of water and wastewater (21st ed.): Washington D.C. variously paged.

American Public Health Association, American Water Works Association, and Water Environment Foundation, 2005b, Fecal Coliform Membrane Filter Procedure, Standard methods for the examination of water and wastewater (21st ed.): Washington D.C. variously paged.

Atkins, John T., Jr., 2007, Water use estimates for West Virginia, 2004: U.S. Geological Survey Open-File Report 2007-1038, $27 \mathrm{p}$.

Cardwell, D.H., Erwin, R.B., and Woodward, H.P., and Lotz, C.W., 1968, Geologic map of West Virginia: West Virginia Geological and Economic Survey, 2 sheets, scale 1:250,000, digital data created in 1998 by the West Virginia Department of Environmental Protection, accessed September 9, 2001, at http://wvgis.wvu.edu.

DeSimone, L.A., 2008, quality of water from domestic wells in principal aquifers of the United States, 1991-2004: U.S. Geological Survey Scientific Investigations Report 20085227, 139 p. (Also available online at http://pubs.usgs.gov/ sir/2008/5227).

Eltschlager, K.K., Hawkins, J.W., Ehler, W.C., and Baldassare, Fred, 2001, Technical measures for the investigation and mitigation of fugitive methane hazards in areas of coal mining: Office of Surface Mining Reclamation and Enforcement, $125 \mathrm{p}$.

Federal Register, 2001, National Primary Drinking Water Regulations; Arsenic and clarifications to compliance and new source contaminants monitoring; Final rule: Federal Register, January 22, 2001, v. 66, no., 14, p. 6975-7066. 
Fenneman, N.M., and Johnson, D.W., 1946, Physical divisions of the United States: U.S. Geological Survey Physiography Committee Special Map, scale 1:7,000,000, accessed September 20, 1999, at http://water.usgs.gov/lookup/ getspatial?physio.

Hem, J.D., 1985, Study and interpretation of the chemical characteristics of natural water: U.S. Geological Survey Water-Supply Paper 2254, 263 p.

Kozar, M.D., and Brown, D.P., 1995, Location and site characteristics of the ambient ground-water-quality-monitoring network in West Virginia: U.S. Geological Survey OpenFile Report 95-130, 48 p.

Kozar, M.D., and Mathes, M.V., 2001, Aquifer-characteristics data for West Virginia: U.S. Geological Survey WaterResources Investigations Report 01-4036, 74 p.

Kozar, M.D., Sheets, C.J., and Hughes, C.A., 2001, Groundwater quality and geohydrology of the Blue Ridge Physiographic Province, New River Basin, Virginia and North Carolina: U.S. Geological Survey Water-Resources Investigations Report 00-4270, 36 p.

Larsen, Daniel, and Mann, Richard, 2005, Origin of high manganese concentrations in coal mine drainage, eastern Tennessee: Journal of Geochemical Exploration, v. 86, p. 143-163.

Mathes, M.V., Jr., Kozar, M.D., and Brown, D.P., 1998, Summary of ground-water quality in West Virginia: West Virginia Division of Environmental Protection, Office of Water Resources, Ground-Water Program, 54 p.

Mathes, M.V., and White, J.S., 2006, Methane in West Virginia ground water: U.S. Geological Survey Fact Sheet 20063011, 2 p.

McAuley, S.D., and Kozar, M.D., 2006, Ground-water quality in unmined areas and near reclaimed surface coal mines in the northern and central Appalachian coal regions, Pennsylvania and West Virginia: U.S. Geological Survey Scientific Investigations Report 2006-5059, 57 p.

McCoy, K.J., and Kozar, M.D., 2007, Relation of chlorofluorocarbon age dates to water quality in aquifers of West Virginia: U.S. Geological Survey Scientific Investigations Report 2006-5221, 36 p.

Multiple Resolution Land Characteristics Consortium, 2007, National Land Cover Dataset, accessed September 20, 2007, at $h t t p: / / w w w . m r l c . g o v / m r l c 2 k \_n l c d . a s p$.

National Research Council, 2001, Arsenic in drinking water2001 update: Washington, D.C., National Academy Press, $226 \mathrm{p}$.
Puente, Celso, 1985, West Virginia ground-water resources, in National water summary, 1984-Hydrologic events, selected water-quality trends, and ground-water resources: U.S. Geological Survey Water-Supply Paper 2275, p. 439-446.

Rose, A.W., and Cravotta, C.A., III, 1998, Geochemistry of coal-mine drainage, in Brady, K.B.C., Smith, M.W., and Schueck, J.H., eds.,Coal mine drainage prediction and pollution prevention in Pennsylvania: Harrisburg, Pa., Pennsylvania Department of Environmental Protection, 5600-BKDEP2256, p. 1.1-1.22.

Ruddy, B.C., Lorenz, D.L., and Mueller, D.K., 2006, Countylevel estimates of nutrient inputs to the land surface of the conterminous United States, 1982-2001: U.S. Geological Survey Scientific Investigations Report 2006-5012, p. 17.

SAS Institute Inc., 1999, SAS/STAT Users Guide, version 8: Cary, N.C., SAS Institute Inc.

TIBCO Software Inc., 2008, TIBCO Spotfire S-PLUS $® 8.1$ guide to stats, Volumes 1 and 2: Palo Alto, Calif., TIBCO Software Inc. p.558.

Toccalino, P.L., Norman, J.E., Booth, N.L., and Zogorski, J.S., 2008, Health-based screening levels: A tool for evaluating what water-quality data may mean to human health: U.S. Geological Survey National Water-Quality Assessment Program, accessed July 22, 2009, at http://water.usgs.gov/ nawqa/HBSL/.

U.S. Census Bureau, 2002, 2000 Census of population block group density dataset, accessed June 30, 2002, at $h t t p: / /$ wvgis.wvu.edu.

U.S. Environmental Protection Agency, 1999, Proposed radon in drinking water rule: Washington, D.C., U.S. Environmental Protection Agency, Office of Water, EPA 815-F-99-006, $6 \mathrm{p}$.

U.S. Environmental Protection Agency, 2005, Toxicological review of zinc and compounds: In support of summary information on the Integrated Risk Information System (IRIS): EPA/635/R-05/002, 83 p.

U.S. Environmental Protection Agency, 2009a, Integrated Risk Information Service (IRIS) Summary for Manganese, accessed September 14, 2009, at http://www.epa.gov/ncea/ iris/subst/0373.htm.

U.S. Environmental Protection Agency, 2009b, National Primary Drinking Water Regulations, accessed February 11, 2011, at http://www.epa.gov/ogwdw/consumer/pdf/mcl.pdf.

U.S. Environmental Protection Agency, 2012, 2012 Edition of the Drinking Water Standards and Health Advisories, accessed August 30, 2012, at http://water.epa.gov/action/ advisories/drinking/upload/dwstandards2012.pdf. 
U.S. Geological Survey, 1998, Physical divisions of the United States, accessed February 3, 2000, at http://water.usgs.gov/ lookup/getspatial?physio.

U.S. Geological Survey, 2006, Collection of water samples (ver. 2.0): U.S. Geological Survey Techniques of WaterResources Investigations, book 9, chap. A4, accessed September 22, 2009, at http://pubs.water.usgs.gov/twri9A4/.

West Virginia Department of Environmental Protection, 2005, West Virginia county boundaries, accessed November 24, 2009, at http://wvgis.wvu.edu/data/dataset.php?ID=136.

West Virginia Department of Environmental Protection, 2009, Watershed Management programs, accessed November 24, 2009, at http://www.wvdep.org/item. cfm? ssid $=11 \&$ ss 1 id $=399$.

Wetzel, R.G., 2001, Limnology, lake and river ecosystems (3d ed.): San Diego, Calif., Academic Press, 1006 p.

White, J.S., and Mathes, M.V., 2006, Dissolved-gas concentrations in ground water in West Virginia, 1997-2005: U.S. Geological Survey Data Series 156, 8 p.

Wilde, F.D., Radtke, D.B., Gibs, Jacob, and Iwatsubo, R.T., eds., 2004, Processing of water samples (vers. 2.1): U.S. Geological Survey Techniques of Water-Resources Investigations, book 9, chap. A5, accessed September 22, 2009, at http://pubs.water.usgs.gov/twri9A5/.

World Health Organization, 2006, Guidelines for drinkingwater quality, $3 \mathrm{~d}$ ed., incorporating first and second addenda: Volume 1-Recommendations: Geneva, World Health Organization, 494 p.

Zogorski, J.S., Carter, J.M., Ivahnenko, Tamara, Lapham, W.W., Moran, M.J., Rowe, B.L., Squillace, P.J., and Toccalino, P.L., 2006, The quality of our Nation's watersVolatile organic compounds in the Nation's ground water and drinking-water supply wells: U.S. Geological Survey Circular 1292, $101 \mathrm{p}$. 

Prepared by the West Trenton Publishing Service Center

For more information, write to:

West Virginia Water Science Center

U.S. Geological Survey

11 Dunbar Street

Charleston, WV 25301

http://wv.usgs.gov/ 
